\title{
ASSESSING THE GROWING SEASON CARBON BUDGET OF AN ARCTIC SEDGE FEN
}

\author{
by \\ JONATHAN VANDEWINT
}

A thesis submitted to the Faculty of Graduate and Postdoctoral Affairs in partial fulfillment of the requirements for the degree of

\author{
Master of Science \\ in
}

Geography

Carleton University

Ottawa, Ontario, Canada

(C) 2011

Jonathan Vandewint 


\section{Library and Archives \\ Canada}

Published Heritage Branch

395 Wellington Street

Ottawa ON K1A 0N4

Canada
Bibliothèque et

Archives Canada

Direction du

Patrimoine de l'édition

395 , rue Wellington

Ottawa ON K1A 0N4

Canada
Your file Votre référence

ISBN: 978-0-494-81683-7

Our file Notre référence

ISBN: 978-0-494-81683-7
NOTICE:

The author has granted a nonexclusive license allowing Library and Archives Canada to reproduce, publish, archive, preserve, conserve, communicate to the public by telecommunication or on the Internet, loan, distribute and sell theses worldwide, for commercial or noncommercial purposes, in microform, paper, electronic and/or any other formats.

The author retains copyright ownership and moral rights in this thesis. Neither the thesis nor substantial extracts from it may be printed or otherwise reproduced without the author's permission.
AVIS:

L'auteur a accordé une licence non exclusive permettant à la Bibliothèque et Archives Canada de reproduire, publier, archiver, sauvegarder, conserver, transmettre au public par télécommunication ou par l'Internet, prêter, distribuer et vendre des thèses partout dans le monde, à des fins commerciales ou autres, sur support microforme, papier, électronique et/ou autres formats.

L'auteur conserve la propriété du droit d'auteur et des droits moraux qui protège cette thèse. $\mathrm{Ni}$ la thèse ni des extraits substantiels de celle-ci ne doivent être imprimés ou autrement reproduits sans son autorisation.
In compliance with the Canadian Privacy Act some supporting forms may have been removed from this thesis.

While these forms may be included in the document page count, their removal does not represent any loss of content from the thesis.
Conformément à la loi canadienne sur la protection de la vie privée, quelques formulaires secondaires ont été enlevés de cette thèse.

Bien que ces formulaires aient inclus dans la pagination, il n'y aura aucun contenu manquant. 


\begin{abstract}
This study provides a complete growing season carbon budget of an arctic sedge fen and an examination of the controls on spatial and temporal variations in carbon dioxide $\left(\mathrm{CO}_{2}\right)$ and methane $\left(\mathrm{CH}_{4}\right)$ fluxes at the small plot and ecosystem scale during the 2009 growing season at Daring Lake, NT. Soil moisture and temperature exerted contro1 over $\mathrm{CH}_{4}$ exchange at the plot scale, while frictional velocity and soil temperature appeared to be equally important at the ecosystem scale. Air temperature, leaf area, and photosynthetically active radiation, were important variables controlling $\mathrm{CO}_{2}$ flux at both the plot and ecosystem scales. Over the growing season, the fen was a sink of $66.3 \mathrm{gC}$ $\mathrm{m}^{-2}$ from $\mathrm{CO}_{2}$ exchange, a source of $2.4 \mathrm{~g} \mathrm{C} \mathrm{m}^{-2}$ from $\mathrm{CH}_{4}$ emission, and a source of $0.9 \mathrm{~g}$ $\mathrm{C} \mathrm{m}^{-2}$ from dissolved organic carbon export, resulting in a net $\mathrm{C}$ uptake of $63 \mathrm{~g} \mathrm{C} \mathrm{m}^{-2}$.
\end{abstract}




\section{ACKNOWLEDGEMENTS}

First and foremost, I thank Dr. Elyn Humphreys. I am grateful for the nostalgic memory of my research in the Arctic. Without her guidance, support, and trust, this thesis would not have been possible. I would also like to thank my assistant Samantha Piquette for her hard work in the field and the enjoyable memories of fishing, swimming, and Han Solo. Many thanks go to Mike Treberg for all things technical. I would like to extend my appreciation to Dr. Ed Gregorich at Agriculture and Agrifood Canada and to Dr. Tim Moore at McGill University for laboratory use and sample processing. Without the funding provided by the Department of Wild life and Environment, Government of N.W.T., through the direction of Steve Mathews, research at the Tundra Ecological Research Station at Daring Lake would not have been as pleasurable.

Fund ing for this project was provided by the Northern Scientific Training Program (NSTP) governed by Indian and Northern Affairs Canada.

I would like to thank my friends and family for their support and distraction while pursuing my masters. 


\section{TAB LE OF CONTENTS}

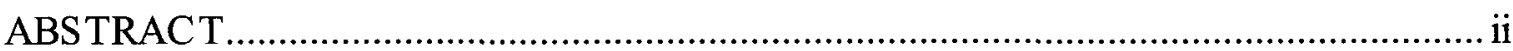

ACKNOWLEDGEMENTS ................................................................................ ii

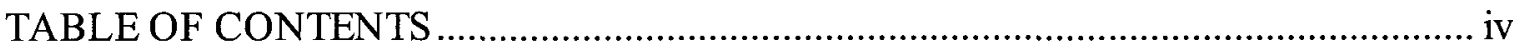

LIST OF TABLES ……………………............................................................. vi

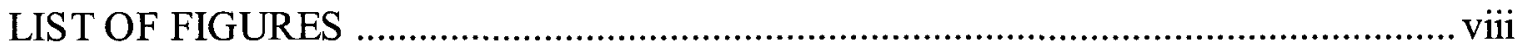

LIST OF SYMBOLS AND ABBREVIATIONS ……................................................ii

$1.0 \quad$ INTRODUCTION ................................................................................. 1

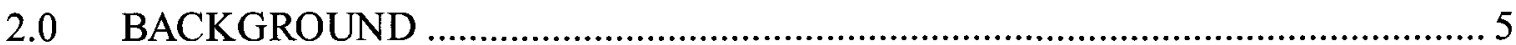

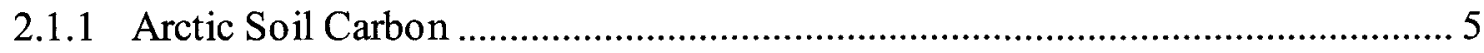

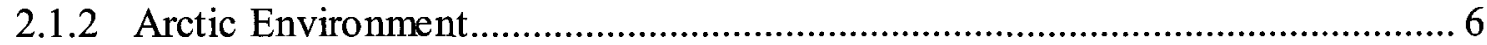

2.1.3 Wetland Environment ........................................................................... 7

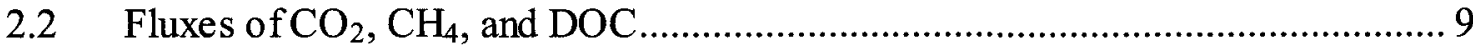

2.2.1 $\mathrm{CO}_{2}, \mathrm{CH}_{4}$, and DOC Cycling ................................................................. 11

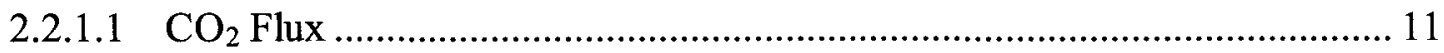

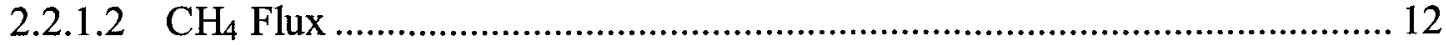

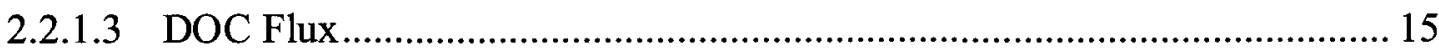

2.2.1.4 Carbon Budget Studies ....................................................................... 16

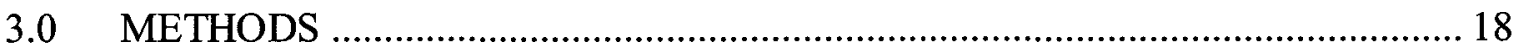

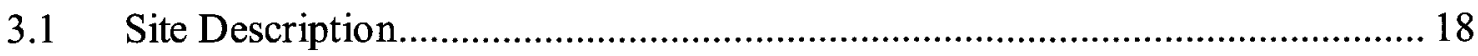

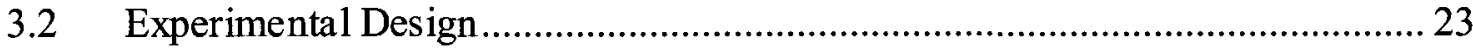

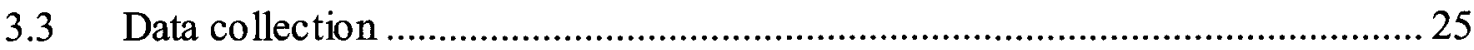

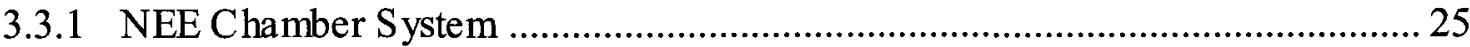

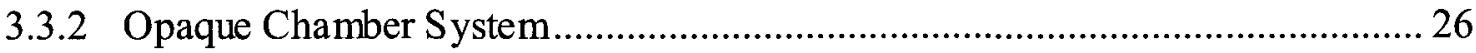

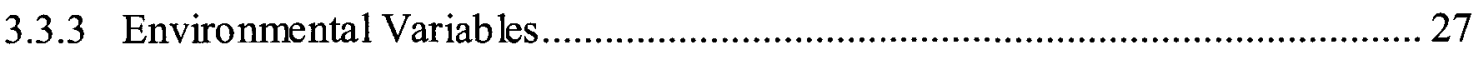

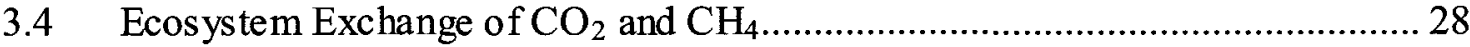

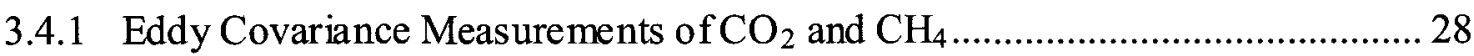

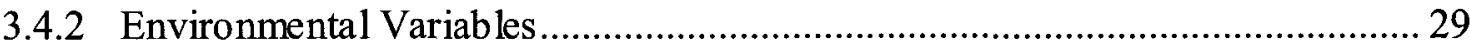

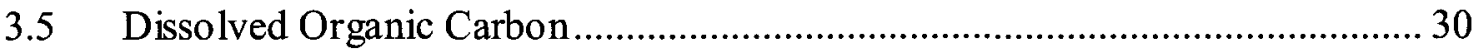

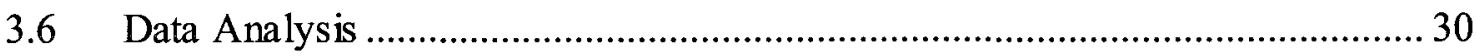




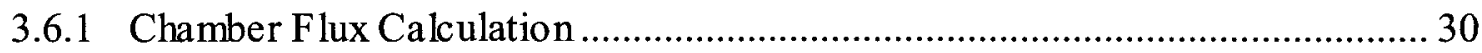

3.6.2 $\mathrm{NEE}$ of $\mathrm{CO}_{2}$ and $\mathrm{CH}_{4}$ Flux Calculation ........................................................ 31

3.6.3 Light-Temperature Response ............................................................................. 32

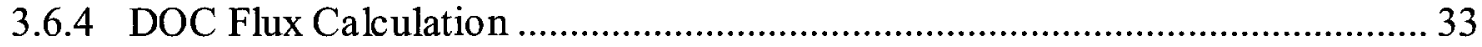

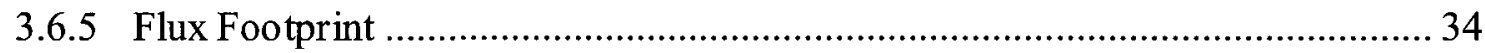

3.6.6 Gap-filling and $\mathrm{C}$ budget Calculations ....................................................... 34

$3.7 \quad$ Statistical Analysis ......................................................................................... 35

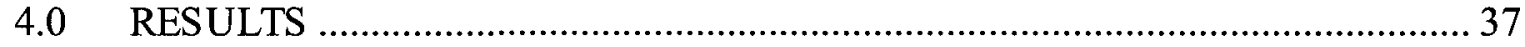

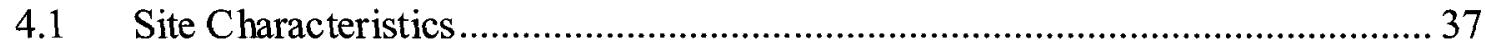

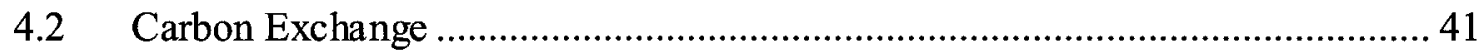

4.2.1 Spatial Variations in $\mathrm{CO}_{2}$ Fluxes ................................................................... 41

4.2.2 Spatial Variations in $\mathrm{CH}_{4}$ Fluxes ..................................................................4 46

4.3.1 Temporal Variations in $\mathrm{CO}_{2}$ Fluxes .............................................................. 51

4.3.2 Temporal Variations in $\mathrm{CH}_{4}$ Fluxes...........................................................5 57

4.4 General Seasonal Trends in $\mathrm{CH}_{4}$ and $\mathrm{CO}_{2}$ Exchange ....................................6 60

4.5.1 Daily Variation in Ecosystem $\mathrm{CH}_{4}$ and $\mathrm{CO}_{2}$ Exchange …..............................63

4.5.2 Diurnal Variation in Ecosystem $\mathrm{CH}_{4}$ and $\mathrm{CO}_{2}$ Flux.........................................66

4.6 Spatial Variation in Ecosystem $\mathrm{CH}_{4}$ and $\mathrm{CO}_{2}$ Flux ....................................... 73

4.7 Growing Season C Budget and GWP ........................................................... 77

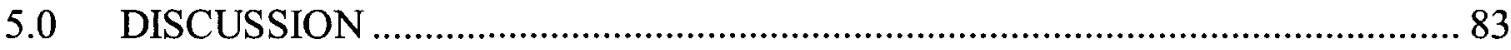

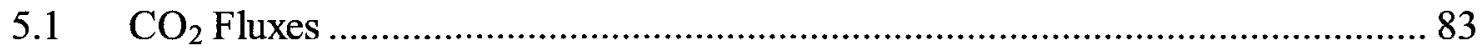

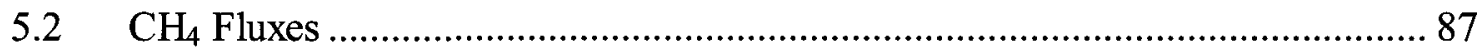

5.3 Carbon Exchange Rates at the Daring Lake Fen and other Arctic Sites ........... 95

5.4 Growing Season Carbon Budget and GWP .................................................. 99

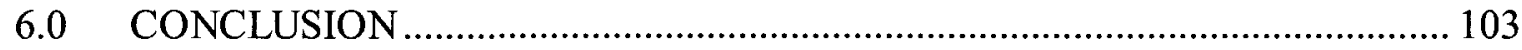

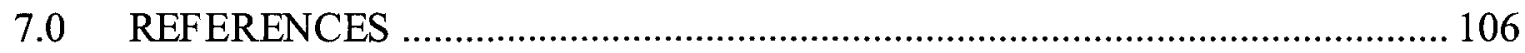




\section{LIST OF TABLES}

Table 1. Soil and vegetation characteristics of the lawn and tussock environments. Values in brackets are the standard error of the mean $( \pm 1 \mathrm{SE})$ for the 8 tussock and 8 lawn collars. Values with different superscripts denote significant differences between communities $(p<0.05)$. * Source (Hayne, 2009).

Table 2. Environmental characteristics of the lawn and tussock communities. Values in brackets are \pm 1 SE. Values with different superscripts denote significant differences between communities $(\mathrm{p}<0.05)$.

Table 3. Average NEE and component fluxes for the two vegetation communities. $\mathrm{NEE}_{\max }$ is the net ecosystem exchange of $\mathrm{CO}_{2}$ for PAR greater than $1000 \mu \mathrm{mol} \mathrm{m} \mathrm{m}^{-2} \mathrm{~s}^{-1}$. GEP $_{\max }$ is the average gross ecosystem production for PAR greater than $1000 \mu \mathrm{mol} \mathrm{m} \mathrm{m}^{-2} \mathrm{~s}^{-}$ 1. ER is the average ecosystem respiration in the dark measured using the flow-through chambers $\left(E R_{F}\right)$ and the static chambers $\left(E R_{S}\right)$. Values in brackets represent $\pm 1 \mathrm{SE}$. Values with different superscripts denote significant differences between communities ( $p$ $<0.05)$

Table 4. Parameters for Equation 3 describing the response of NEE to PAR and chamber air temperature for the two communities. GP $\max _{\max }$ is maximum gross photosynthesis, $\alpha$ is the initial slope of the curve, $R_{10}$ is ecosystem respiration at a reference temperature of 10 ${ }^{\circ} \mathrm{C}, \mathrm{n}$ is the number of observations, $\mathrm{Q}_{10}$ is rate of increase in ER for a $10{ }^{\circ} \mathrm{C}$ increase in temperature, and RMSE is the root mean square error. Values in brackets represent \pm 1 SE. Values with different superscripts denote significant differences between communities $(p<0.05)$.

Table 5. The range and mean $\mathrm{CH}_{4}$ flux for the lawn and tussock communities. Values in brackets represent \pm 1 SE. Values with different superscripts denote significant differences between communities $(\mathrm{p}<0.05)$. The number of samples for lawns and tussocks is 132 .

Table 6. Spearman's rho correlation coefficients showing significant relationships between environmental variables and $\mathrm{CO}_{2}$ fluxes with p-values given in brackets. Net ecosystem exchange ( $\left.\mathrm{NEE}_{\max }\right)$; gross ecosystem production $\left(\mathrm{GEP}_{\max }\right)$; ecosystem respiration (flow-through chamber) $\left(E R_{F}\right)$; ecosystem respiration (static chamber) $\left(E R_{S}\right)$.

Table 7. Spearman's rho correlation coefficients showing significant relationships between environmental variables and ecosystem respiration (static chamber) (ERS), for lawn and tussock communities with $\mathrm{p}$-values given in brackets.

Table 8. Spearman's rho correlation coefficients showing significant relationships between environmental variables and $\mathrm{CH}_{4}$ flux for lawn and tussock communities separately and combined with significant $\mathrm{p}$-values given in brackets. 
Table 9. Spearman's rho correlation coefficients showing significant relationships between $\mathrm{CH}_{4}$ flux and environmental variables for flux values above $12{ }^{\circ} \mathrm{C}$. P- values are given in brackets and considered significant when $\mathrm{p}<0.05$.

Table 10. Parameters for Equation 3 describing the response of NEE to PAR and average ecosystem air temperature for the study period. $\mathrm{GP}_{\max }$ is maximum gross photosynthesis, $\alpha$ is the initial slope of the curve, $R_{10}$ is ecosystem respiration at a reference temperature of $10^{\circ} \mathrm{C}, \mathrm{n}$ is the number of observations, $\mathrm{Q}_{10}$ is rate of increase in ER for a $10{ }^{\circ} \mathrm{C}$ increase in temperature*, RMSE is the root mean square error, and Temp is the average a ir temperature for the study period. Values in brackets indicate approximate standard error.

Table 11. Average daytime $(10 \mathrm{am}-6 \mathrm{pm})$ NEE for footprint distances from tower of 70 $\mathrm{m}$ or less and for distances greater than $70 \mathrm{~m}$ for the three sectors during the study period. Error associated with NEE is $\pm 1 \mathrm{SE}$. Numbers in brackets indicate the number of observations. Different superscript letters indicate significant differences within a column $(\mathrm{p}<0.05)$. NEE, net ecosystem exchange of $\mathrm{CO}_{2}$

Table 12. $\mathrm{CH}_{4}$ input and model parameters for the growing season of 2009 using Equation 5. $\mathrm{T}_{\text {ref, }}$ average temperature for the sampling period, $\mathrm{u} *_{\text {ref }}$, average frictional velocity for the sampling period, a, b, c are fit parameters, RMSE, root-mean standard error, $\mathrm{r}^{2}$, correlation coefficient, $\mathrm{n}$, number of samples. Errors associated with fit parameters are $\pm \mathrm{SE}$. The number of daily averages used was 27 .

Table 13. Average dissolved organic carbon (DOC), slope $(d h / d z)$, and flow rates for three measurement periods during summer of 2009, Daring Lake. Values within brackets ind icate standard error of the mean. The number of samples for each measurement is 3.82

Table 14. Average ecosystem storage change of dissolved organic carbon, DOC, for three measurement periods during the summer of 2009, Daring Lake. Values within brackets indicate standard error of the mean. Positive values indicate loss of DOC from the ecosystem. The number of samples for each measurement is 6 .

Table 15. GWP and modelled carbon balance for the growing season (June 1 - August 31) 2009 at Daring lake, NT. Positive numbers ind icate ecosystem carbon loss and ne gative numbers indicate ecosystem carbon uptake and negative forcing potential to warm atmosphere. 


\section{LIST OF FIGURES}

Figure 1. Map of the research area at Daring Lake, NT with the location of the Tundra Ecological Research Station (TERS), fen and study site (Adapted from Nobrega and Grogan, 2008).

Figure 2. Vegetation map (edited from Obst, 2008) showing the location of micrometeorological tower within the wet fen at Daring Lake, NT. Inner ring represents radius of $70 \mathrm{~m}$ and outer ring a radius of $100 \mathrm{~m}$. Three sectors are delineated: $0^{\circ}-135^{\circ}$ (sedge fen dominated by lawn topography to $\mathrm{NE}$, rocky upland area to $\mathrm{SE}$ ); $135^{\circ}-225^{\circ}$ (sedge fen with tussock topography, small, open water bodies and rocky upland area); $225^{\circ}-360^{\circ}$ (sedge fen and shrub peat mound areas).

Figure 3. Top panel-NE aerial view of Darling Lake, NT including Yamba Lake in top left. Yellow circle gives approximate location of micrometeorological tower. Bottom panel-Micrometeorological setup with a view to the north. Lawn and tussock topography is shown in foreground.

Figure 4. Plot locations of 16 permanent collars installed at Daring Lake, NT, 2009. Closed circles represent lawns and open circles represent tussocks. The closed black square represents micrometeorological tower, open squares represent solar panels, and closed triangle represents the generator. UTM coordinate system in Easting and Northing, Map 12N (North America). Locations are within 2 meter accuracy.

Figure 5. Daily average water table depth relative to the lawn surface, total daily precipitation, and average soil volumetric water content (VWC) for the $0-20 \mathrm{~cm}$ layer of lawns (closed circles) and tussocks (open circles) at Daring Lake, NT from July $11^{\text {th }}$ to August $15^{\text {th }}, 2009$. Error bars represent \pm 1 standard error $( \pm 1 \mathrm{SE})$.

Figure 6. Average daily air temperature (solid line), average daily daytime air temperature (PAR $>10 \mathrm{~W} \mathrm{~m}^{-2}$ ) (dotted line), average soil temperature at $2 \mathrm{~cm}$ depth for lawns (closed circles) and tussocks (open circles), daily photosynthetically active radiation (PAR), and thaw layer depth at Daring Lake, NT from July $11^{\text {th }}$ to August $15^{\text {th }}$, 2009. Error bars represent $\pm 1 \mathrm{SE}$. The number of samples for each $2 \mathrm{~cm}$ soil temperature symbol is 8 . The number of samples for each thaw layer depth symbol is 15 .

Figure 7. The top and bottom panels show the relationship between net ecosystem exchange of $\mathrm{CO}_{2}$ (NEE) and photosynthetically active radiation (PAR) for lawns and tussocks, respectively. The light response curves are shown as solid lines. Curves (solid lines) are determined using Equation 3 with parameters listed in Table 4.

Figure 8. The relationship between net ecosystem exchange of $\mathrm{CO}_{2}\left(\mathrm{NEE}_{\max }\right)$ (top panel) and gross ecosystem exchange of $\mathrm{CO}_{2}\left(\mathrm{GEP}_{\max }\right)$ (bottom panel) to \% vascular. Error bars represent $\pm 1 \mathrm{SE}$. The number of samples for each symbol is 13. Lines are given for 
significant linear regressions $\left(\mathrm{NEE}_{\max }=-0.04(\%\right.$ Vascular $)+0.55, \mathrm{r}^{2}=0.56 ; \mathrm{GEP}_{\max }=-$ $0.05(\%$ Vascular $\left.)-0.92, \mathrm{r}^{2}=0.43\right)$.

Figure 9. Relationship between $\mathrm{CH}_{4}$ Flux and volumetric water content (VWC) for lawns (dark circles) and tussocks (open circles). Error bars represent $\pm 1 \mathrm{SE}$. The number of samples for each symbol is 16 . Lines are given for significant linear regressions $\left(\mathrm{CH}_{4}\right.$ Flux= 37.35(VWC) $\left.+18.62, \mathrm{r}^{2}=0.24\right)$.

Figure 10. Relationship between $2 \mathrm{~cm}$ soil temperature and $\mathrm{CH}_{4}$ flux for lawns (dark circles) and tussocks (open circles). Error bars represent $\pm 1 \mathrm{SE}$. The number of samples for each symbol is 16 . Lines are given for significant linear regressions $\left(\mathrm{CH}_{4} \mathrm{Flux}=\right.$ 11.72 (Temperature) - $128.1, \mathrm{r}^{2}=0.66$ ).

Figure 11. The relationship between ecosystem respiration (static chamber) (ERS) and $\mathrm{CH}_{4}$ flux for lawns (dark circles) and tussocks (open circles). Error bars represent $\pm 1 \mathrm{SE}$. The number of samples for each symbol is 16 . Lines are given for significant linear

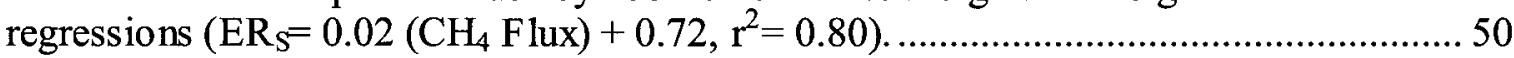

Figure 12. The average daily flux for lawns (closed circles) and tussocks (open circles) using the flow-through and opaque static chamber systems. Gross ecosystem production (GEP); net ecosystem exchange (NEE); ecosystem respiration (flow-through chamber) $\left(E R_{F}\right)$; ecosystem respiration (static chamber) $\left(E R_{S}\right)$. Error bars represent $\pm 1 \mathrm{SE}$. The number of samples for each symbol is 8 .

Figure 13. The relationship between ecosystem respiration (flow-through chamber), $E R_{F}$, and temperature at $2 \mathrm{~cm}$ depth (top panel), average volumetric water content (VWC) (middle panel), and water table depth (bottom panel). Closed circles represent lawns and open circles represent tussocks. Error bars represent $\pm 1 \mathrm{SE}$. The number of samples for each symbol is 8 . Lines are given for significant linear regressions. Top panel lawns $\left(E R_{\mathrm{F}}=0.1\right.$ (Temperature) $\left.+0.24, \mathrm{r}^{2}=0.77\right)$ and tussocks $\left(\mathrm{ER}_{\mathrm{F}}=0.13\right.$ (Temperature) -0.27 , $\left.\mathrm{r}^{2}=0.64\right)$; middle panel $\left(\mathrm{ER}_{\mathrm{F}}=2.16\right.$ (Temperature $\left.)+1.13, \mathrm{r}^{2}=0.25\right)$; bottom panel $\left(\mathrm{ER}_{\mathrm{F}}=\right.$ 0.11 (Temperature) $+2.89, \mathrm{r}^{2}=0.25$ )

Figure 14. The relationship between ecosystem respiration (static chamber) $\left(E_{\mathrm{S}}\right)$ and temperature at $2 \mathrm{~cm}$ depth (top panel), average volumetric water content (VWC) (middle panel), and $\mathrm{CH}_{4} \mathrm{Flux}$ (bottom panel). Closed circles represent lawns and open circles represent tussocks. Error bars represent $\pm 1 \mathrm{SE}$. The number of samples for each symbol is 8. Lines are given for significant linear regressions. Top panel ( $\mathrm{L}: \mathrm{ER}_{\mathrm{S}}=0.12$ (Temperature) $-0.17, \mathrm{r}^{2}=0.82 ; \mathrm{T}: \mathrm{ER}_{\mathrm{S}}=0.07$ (Temperature) $+0.41, \mathrm{r}^{2}=0.37$ ), middle panel $\left(\mathrm{L}: \mathrm{ER}_{\mathrm{S}}=-3.04(\mathrm{VWC})+4.01, \mathrm{r}^{2}=0.36 ; \mathrm{T}: \mathrm{ER}_{\mathrm{S}}=2.54(\mathrm{VWC})+0.14, \mathrm{r}^{2}=0.27\right)$, bottom panel (L: $\mathrm{ER}_{\mathrm{S}}=0.01\left(\mathrm{CH}_{4}\right.$ Flux $)+0.62, \mathrm{r}^{2}=0.28 ; \mathrm{T}: \mathrm{ER}_{\mathrm{S}}=0.04\left(\mathrm{CH}_{4} \mathrm{Flux}\right)-0.02$, $\left.r^{2}=0.36\right)$.

Figure 15. The relationship between $\mathrm{CH}_{4}$ flux and temperature at $2 \mathrm{~cm}$ depth (top panel), average volumetric water content (VWC) (middle panel), and water table depth (bottom panel). Error bars represent $\pm 1 \mathrm{SE}$. The number of samples for each symbol is 8 . Lines 
are given for significant linear regressions. Top panel $\left(\mathrm{CH}_{4} \mathrm{Flux}=1.01\right.$ (Temperature) + $\left.20.5, \mathrm{r}^{2}=0.15\right)$, middle panel $\left(\mathrm{CH}_{4} \mathrm{Flux}=63.16(\mathrm{VWC})+7.97, \mathrm{r}^{2}=0.57\right)$, bottom panel $\left(\mathrm{L}: \mathrm{CH}_{4} \mathrm{Flux}=1.39(\mathrm{WT})+70.54, \mathrm{r}^{2}=0.17 ; \mathrm{T}: \mathrm{CH}_{4} \mathrm{Flux}=2.07(\mathrm{WT})+52.94, \mathrm{r}^{2}=0.47\right) .59$

Figure 16 . Daily daytime (10 am $-6 \mathrm{pm})$ average eddy covariance and chamber measurements of $\mathrm{CH}_{4}$ flux and net ecosystem exchange $\mathrm{CO}_{2}(\mathrm{NEE})$. Eddy covariance fluxes are shown for days when there were at least 6 half hours with good quality measurements. Chamber fluxes are means of 8 different collar measurements for each plotted day. Error bars represent \pm 1 SE. Chamber fluxes are represented by closed circles for lawns, open circles for tussocks, triangles for shrub peat mounds, and open squares represent tower fluxes.

Figure 17. The relationship between daily daytime $(10 \mathrm{am}-6 \mathrm{pm}) \mathrm{CH}_{4}$ flux and $5 \mathrm{~cm}$ soil temperature (top panel) and friction velocity $\left(\mathrm{u}_{*}\right)$ (bottom panel). Error bars represent \pm 1 SE. The number of $30 \mathrm{~min}$ fluxes for each symbol ranges from 6 to 16 .

Figure 18 . The relationship between daily daytime $(10 \mathrm{am}-6 \mathrm{pm})$ net ecosystem exchange of $\mathrm{CO}_{2}(\mathrm{NEE})$ and photosynthetically active radiation (PAR). The top panel illustrates the relationship for air temperature below $12^{\circ} \mathrm{C}$ and the bottom panel is for air temperature above $12^{\circ} \mathrm{C}$. Lines are given for significant linear regressions. Top Panel: $\left(\mathrm{NEE}=-0.0006(\mathrm{PAR})-2.52, \mathrm{r}^{2}=0.05\right)$ and bottom panel: $\left(\mathrm{NEE}=-0.003-0.81, \mathrm{r}^{2}=0.25\right)$. Error bars represent $\pm 1 \mathrm{SE}$. The number of 30 min fluxes for each symbol ranges from 6 to 16 .

Figure 19. Diurnal variation of $\mathrm{CH}_{4}$ flux, friction velocity ( $\mathrm{u} *$ ), and $5 \mathrm{~cm}$ soil temperature for days with different turbulence cond itions. Column 1 represents whole days $(14<$ half-hour measurements < 49) when mean $\mathrm{u} *$ was above $0.24 \mathrm{~m} \mathrm{~s}^{-1}$ and the standard deviation (SD) was below $0.07 \mathrm{~m} \mathrm{~s}^{-1}$, column 2 represents $\mathrm{u} *$ below $0.24 \mathrm{~m} \mathrm{~s}^{-1}$ and the SD was below $0.07 \mathrm{~m} \mathrm{~s}^{-1}$, and column 3 represents mixed $\mathrm{u} *$ (all other days) with a SD above $0.07 \mathrm{~m} \mathrm{~s}^{-1}$. Half-hour measurements with $\mathrm{u} *$ below $0.1 \mathrm{~m} \mathrm{~s}^{-1}$ were not included. Error bars represent $\pm 1 \mathrm{SE}$. The number of 30 min measurements for each symbol ranges from 10 to 21

Figure 20. The relationship between $30 \mathrm{~min} \mathrm{CH}_{4}$ flux and frictional velocity, $\mathrm{u} *$. Data are binned by $\mathrm{u} *\left(0.03 \mathrm{~m} \mathrm{~s}^{-1}\right.$ wide) and separated by temperature above (open circles) and below (closed circles) $12^{\circ} \mathrm{C}$. Error bars represent $\pm 1 \mathrm{SE}$. The number of $30 \mathrm{~min}$ fluxes for each symbol ranges from 6 to 53 .

Figure 21. The relationship between $30 \mathrm{~min} \mathrm{CH}_{4}$ flux and $5 \mathrm{~cm}$ soil temperature. Data is binned by temperature $\left(0.5^{\circ} \mathrm{C}\right)$ and separated by $\mathrm{u}_{*}$. Open circles represent data below $0.24 \mathrm{~m} \mathrm{~s}^{-1}$ and closed circles represent data above $0.24 \mathrm{~m} \mathrm{~s}^{-1}$. Error bars represent $\pm 1 \mathrm{SE}$. The number of $30 \mathrm{~min}$ fluxes for each symbol ranges from 5 to 58 .

Figure 22. The relationship between 30 min $\mathrm{CH}_{4}$ flux and all variables above $12{ }^{\circ} \mathrm{C}$ separated by $\mathrm{CH}_{4}$ flux above and below $30 \mathrm{nmol} \mathrm{m}^{-2} \mathrm{~s}^{-1}$. Closed circles represent $\mathrm{CH}_{4}$ flux below $30 \mathrm{nmol} \mathrm{m}^{-2} \mathrm{~s}^{-1}$ and open circles represent $\mathrm{CH}_{4}$ flux above $30 \mathrm{nmol} \mathrm{m}^{-2} \mathrm{~s}^{-1} \ldots 70$ 
Figure 23. The relationship between nighttime (PAR less than $20 \mu \mathrm{mol} \mathrm{m}^{-2} \mathrm{~s}^{-1}$ ) net ecosystem exchange of $\mathrm{CO}_{2}, \mathrm{NEE} \mathrm{CO}_{2}$, and frictional velocity, $\mathrm{u} *$. Data are binned by $\mathrm{u} *$ $\left(0.05 \mathrm{~m} \mathrm{~s}^{-1}\right.$ wide) and separated by temperature above (open circles) and below (closed circles) $8.5^{\circ} \mathrm{C}$. Positive values indicate net ecosystem carbon loss. Error bars represent $\pm 1 \mathrm{SE}$. The number of samples for each symbol ranges from 18 to 70 .

Figure 24. The relationship between net ecosystem exchange of $\mathrm{CO}_{2}, \mathrm{NEE}$, and photosynthetically active radiation, PAR for the study period. Symbols correspond to 30 minute averages of NEE which were above the frictional velocity threshold of $0.1 \mathrm{~m} \mathrm{~s}^{-1}$ at night $\left(\mathrm{PAR}<20 \mu \mathrm{mol} \mathrm{m} \mathrm{m}^{-2} \mathrm{~s}^{-1}\right)$. The curved line corresponds to Equation 3 with parameters listed in Table 10. Negative values represent ecosystem uptake of carbon. .72

Figure 25. The relationship between 30 minute averages of $\mathrm{CH}_{4}$ flux, friction velocity, $\mathrm{u}_{*}$, and footprint distance for three spatially different areas within the fetch of the eddy covariance tower. Closed circles represent sector $1\left(0^{\circ}-135^{\circ}\right)$, open circles represent sector $2\left(135^{\circ}-225^{\circ}\right)$, and closed triangles represent sector $3\left(225^{\circ}-360^{\circ}\right)$. Data are binned by footprint $(10 \mathrm{~m}$ wide $)$ and $\mathrm{u} *\left(0.05 \mathrm{~m} \mathrm{~s}^{-1}\right.$ wide $)$. Error bars represent $\pm 1 \mathrm{SE}$. The number of samples for each symbol ranges from 6 to 36 .

Figure 26. The relationship between net ecosystem exchange of $\mathrm{CO}_{2}, \mathrm{NEE}$, and footprint distance for three spatially different areas within the fetch of the eddy covariance tower. Closed circles represent sector $1\left(0^{\circ}-135^{\circ}\right)$, open circles represent sector $2\left(135^{\circ}-225^{\circ}\right)$, and closed triangles represent sector $3\left(225^{\circ}-360^{\circ}\right)$. Error bars represent $\pm 1 \mathrm{SE}$. The number of samples for each symbol ranges from 9 to 50 .

Figure 27. Half-hour measured net ecosystem exchange (NEE) (top), gap-filled daily NEE (middle) and cumulative NEE (bottom) for 1 June to 31 August 2009. Positive values represent a net $C$ loss to the atmosphere while negative values represent a net $C$ accumulation by the ecosystem.

Figure 28. Daily integrated mean values of eddy covariance $\mathrm{CH}_{4}$ emission versus modelled emission rates from Equation 5 and modelled parameters from Table 12. $\mathrm{CH}_{4}$, methane.

Figure 29. Daily $\mathrm{CH}_{4}$ flux (middle) and cumulative $\mathrm{CH}_{4}$ flux (bottom), modelled, for 1 June to 31 August 2009. Positive values result in net $\mathrm{C}$ loss to atmosphere. $\mathrm{CH}_{4}$, methane. 


\section{LIST OF SYMBOLS AND ABBREVIATIONS}

\begin{tabular}{|c|c|c|}
\hline Symbol & Units & Definition \\
\hline$\alpha$ & $\begin{array}{l}\mathrm{mol} \mathrm{CO}_{2} \mathrm{~mol}^{-1} \\
\text { photons }\end{array}$ & Effective quantum yield \\
\hline A & $\mathrm{m}^{2}$ & area \\
\hline $\mathrm{C}$ & & carbon \\
\hline $\mathrm{CH}_{3} \mathrm{COH}$ & & methanol \\
\hline $\mathrm{CH}_{3} \mathrm{COOH}$ & & acetate substrate \\
\hline $\mathrm{CO}_{2}$ & & carbon dioxide \\
\hline $\mathrm{CH}_{4}$ & & methane \\
\hline $\mathrm{cm}$ & & centimeters \\
\hline DIC & & dissolved inorganic carbon \\
\hline DOC & & dissolved organic carbon \\
\hline $\mathrm{dh} / \mathrm{dz}$ & $\mathrm{m} \mathrm{m}^{-1}$ & slope \\
\hline $\mathrm{dx} / \mathrm{dt}$ & $\mathrm{ppm} \mathrm{s}^{-1}$ & gas species mixing ratio \\
\hline${ }^{\circ} \mathrm{C}$ & & degrees Celsius \\
\hline EC & & eddy covariance \\
\hline$\overline{E R}$ & $\mu \mathrm{molCO}_{2} \mathrm{~m}^{-2} \mathrm{~s}^{-1}$ & ecosystem respiration of $\mathrm{CO}_{2}$ \\
\hline$\overline{\mathrm{ER}_{\mathrm{a}}}$ & $\mu \mathrm{molCO}_{2} \mathrm{~m}^{-2} \mathrm{~s}^{-1}$ & autotrophic respiration \\
\hline$\overline{\mathrm{ER}_{\mathrm{h}}}$ & $\mu \mathrm{molCO}_{2} \mathrm{~m}^{-2} \mathrm{~s}^{-1}$ & heterotrophic respiration \\
\hline $\mathrm{ER}_{\mathrm{F}}$ & $\mu \mathrm{molCO}_{2} \mathrm{~m}^{-2} \mathrm{~s}^{-1}$ & ecosystem respiration of $\mathrm{CO}_{2}$ flow-through chamber \\
\hline $\mathrm{ER}_{\mathrm{S}}$ & $\mu \mathrm{molCO}_{2} \mathrm{~m}^{-2} \mathrm{~s}^{-1}$ & ecosystem respiration of $\mathrm{CO}_{2}$ static chamber \\
\hline $\mathrm{F}$ & & flux \\
\hline FID & & flame-ionization detector \\
\hline FMGA & & closed-path fast methane gas analyzer \\
\hline GEP & $\mu \mathrm{mol} \mathrm{CO} 2 \mathrm{~m}^{-2} \mathrm{~s}^{-1}$ & gross ecosystem photosynthesis \\
\hline $\mathrm{GEP}_{\max }$ & $\mu \mathrm{mol} \mathrm{CO} 2 \mathrm{~m}^{-2} \mathrm{~s}^{-1}$ & $\begin{array}{l}\text { gross ecosystem photosynthesis at maximum PAR } \\
\text { (field) }\end{array}$ \\
\hline $\mathrm{GP}_{\max }$ & $\mu \mathrm{mol} \mathrm{CO}_{2} \mathrm{~m}^{-2} \mathrm{~s}^{-1}$ & $\begin{array}{l}\text { gross ecosystem photosynthesis at maximum PAR } \\
\text { (model) }\end{array}$ \\
\hline GWP & & global warming potential \\
\hline $\mathrm{H}$ & & hydrogen \\
\hline $\mathrm{H}_{2}$ & & hydrogen gas \\
\hline $\mathrm{H}_{2} \mathrm{O}$ & & water \\
\hline ha & & hectares \\
\hline IPCC & & international panel on climate change \\
\hline IRGA & & infrared gas analyzer \\
\hline$\kappa$ & & permeability constant $10^{-4}$ \\
\hline $\mathrm{km}$ & & kilometers \\
\hline 1 & & liter \\
\hline LAI & & leaf area index \\
\hline $\mathrm{m}$ & & meters \\
\hline $\mathrm{mg}$ & & milligrams \\
\hline
\end{tabular}




\begin{tabular}{|c|c|c|}
\hline $\min$ & & minutes \\
\hline $\mathrm{ml}$ & & milliliters \\
\hline $\mathrm{mm}$ & & millimeters \\
\hline $\mathrm{N}$ & & north \\
\hline NEE & $\mu \mathrm{molCO}_{2} \mathrm{~m}^{-2} \mathrm{~s}^{-1}$ & net ecosystem exchange of $\mathrm{CO}_{2}$ (field) \\
\hline $\mathrm{NEE}_{\max }$ & $\mu \mathrm{molCO}_{2} \mathrm{~m}^{-2} \mathrm{~s}^{-1}$ & net ecosystem exchange of $\mathrm{CO}_{2}$ (model) \\
\hline NPP & & plant productivity \\
\hline NT & & north west territories, Canada \\
\hline$\overline{\mathrm{O}}$ & & oxygen atom \\
\hline$\overline{\mathrm{O}_{2}}$ & & oxygen molecule (air) \\
\hline$\overline{\mathbf{P}}$ & $\mathrm{Pa}$ & atmospheric pressure \\
\hline$\overline{\text { PAR }}$ & $\mu \mathrm{mol}$ photons $\mathrm{m}^{-2} \mathrm{~s}^{-1}$ & photosynthetically active radiation \\
\hline $\mathrm{Pg}$ & & petagram \\
\hline $\mathrm{ppm}$ & & parts per million \\
\hline $\mathrm{Q}$ & $\mathrm{m}^{3} \mathrm{~s}^{-1}$ & discharge rate \\
\hline$\overline{\mathrm{Q}_{10}}$ & & rate of increase in respiration over $10^{\circ} \mathrm{C}$ \\
\hline $\mathrm{R}$ & $\mathrm{J} \mathrm{mol}^{-1} \mathrm{~K}^{-1}$ & ideal gas constant $8.314 \mathrm{~J} \mathrm{~mol}^{-1} \mathrm{~K}^{-1}$ \\
\hline$\overline{\mathrm{R}_{\text {ref }}}$ & $\mu \mathrm{molCO}_{2} \mathrm{~m}^{-2} \mathrm{~s}^{-1}$ & respiration at reference temperature $T_{\text {ref }}$ \\
\hline $\mathrm{R}_{10}$ & $\mu \mathrm{molCO}_{2} \mathrm{~m}^{-2} \mathrm{~s}^{-1}$ & respiration at reference temperature of $10^{\circ} \mathrm{C}$ \\
\hline SE & & standard error of the mean \\
\hline$\overline{\text { SOC }}$ & & soil organic carbon \\
\hline $\mathrm{T}$ & ${ }^{\circ} \mathrm{C}$ or Kelvin & temperature \\
\hline TERS & & tundra ecosystem research station \\
\hline $\mathrm{T}_{\text {ref }}$ & ${ }^{\circ} \mathrm{C}$ & reference temperature of $10^{\circ} \mathrm{C}$ \\
\hline $\mathrm{U} *$ & $\mathrm{~m} \mathrm{~s}^{-1}$ & frictional velocity \\
\hline $\mathrm{u}^{*}$ ref & $\mathrm{m} \mathrm{s}^{-1}$ & mean frictional velocity \\
\hline $\mathrm{V}$ & $\mathrm{m}^{3}$ & volume \\
\hline VPD & $\mathrm{kPa}$ & vapour pressure deficit \\
\hline VWC & $\mathrm{m}^{3} \mathrm{~m}^{-3}$ & volumetric water content \\
\hline WT & $\mathrm{cm}$ & water table depth \\
\hline
\end{tabular}




\subsection{INTRODUCTION}

Global surface temperatures have risen by $0.6^{\circ} \mathrm{C}$ since the beginning of the industrial revolution (IPCC, 2007). General circulation models forecast disproportionate increases in temperature and precipitation in high latitudes when compared to temperate and tropical regions (IPCC, 2007; ACIA, 2004). In the last fifty years, parts of Siberia, Alaska, and north-western Canada have experienced $2-3{ }^{\circ} \mathrm{C}$ warming (ACIA, 2004), and by the end of the $21^{\text {st }}$ century, a $4-8^{\circ} \mathrm{C}$ temperature rise is expected in the Arctic (IPCC, 2007). The rate and magnitude of biogeochemical cycling may be affected in arctic ecosystems due to the potential to respond strongly and rapidly to changes in temperature and moisture conditions (Oechel and Vourlitis, 1994; Zhuang et al., 2006; Zimov et al., 2006). Terrestrial surface-atmosphere feedbacks to the climate system occur through exchanges of energy and water vapour and through exchanges of greenhouse gases such as carbon dioxide $\left(\mathrm{CO}_{2}\right)$ and methane $\left(\mathrm{CH}_{4}\right)(\mathrm{Chapin}$ et al. 2000). A better understanding of the carbon (C) cycle of arctic terrestrial ecosystems and the biotic and abiotic factors that affect them is particularly important as these vast areas store large amounts of $\mathrm{C}$ in soils that remain frozen or saturated for much of the year. Moreover, with climate change in these regions, this $\mathrm{C}$ pool could become susceptible to decomposition and subsequently be released to the atmosphere. Should warming in northern areas promote the loss of $\mathrm{C}$ to the atmosphere, this could result in a positive feedback to climate change. Increasing concentrations of $\mathrm{CO}_{2}$ and $\mathrm{CH}_{4}$ gas in the atmosphere results in positive radiative forcing which leads to increased surface temperatures (ACIA, 2004). Understanding how arctic ecosystems respond to and influence global warming is critical in order to model and predict future climate change. 
Globally, it is estimated that there is $1672 \mathrm{Pg}$ of organic $\mathrm{C}$ in northern permafrost soils (Tarnocai et al., 2009). Globally, northern circumpolar regions have approximately $496 \mathrm{Pg}$ of $\mathrm{C}$ in the top $1 \mathrm{~m}$ and $1024 \mathrm{Pg}$ ofC in the top $3 \mathrm{~m}$ of soil with the remaining $\mathrm{C}$ in deeper yedoma and deltaic deposits (Tarnocai et al., 2009). With the current atmospheric $\mathrm{C}$ pool estimated to be $750 \mathrm{Pg}$, the below ground northern circumpolar $\mathrm{C}$ pool represents over twice the amount presently stored in the atmosphere (Kuhry et al., 2010).

The $\mathrm{C}$ fluxes that determine the $\mathrm{C}$ budget of terrestrial wetland ecosystems include $\mathrm{CO}_{2}$ and $\mathrm{CH}_{4}$ fluxes as well as the flow of dissolved organic $\mathrm{C}$ (DOC) and inorganic C (DIC) primarily through groundwater flow. The majority of studies examining ecosystem-scale terrestrial $\mathrm{C}$ cycling in arctic terrain have been carried out in Alaska (Vourlitis and Oechel, 1999; Vourlitis et al., 2000; Kwon et al., 2006), Siberia (Corradi et al., 2005; Grondahl et al., 2008; Sachs et al., 2008; Wille et al., 2008; Merbold et al., 2009; Gazovic et al., 2010), and Europe and Scandinavia (Soegaard and Nordstrom, 1999; Friborg et al., 2000; Aurela et al., 2007; Riutta et al., 2007; Fox et al., 2008; Nilsson et al., 2008). In Canada, small plot-scale studies have been carried out in the High Arctic (Welker et al., 2004; Oberbauer et al., 2007) and in the Southern Arctic to examine spatial variations in $\mathrm{CO}_{2}$ exchanges for a variety of upland and wetland tundra types (Griffis et al., 2000; Nobrega and Grogan, 2008; Hayne, 2009; Wilson and Humphreys, 2010), but very few studies have investigated whole ecosystem-scale fluxes of the terrestrial $\mathrm{CO}_{2}$ cycle in Canada's Arctic in either wetland (Griffis et al., 2000; Lafleur et al., 2001) or upland tundra (Lafleur and Humphreys, 2008). Elsewhere, only a limited number of studies have examined both $\mathrm{CO}_{2}$ and $\mathrm{CH}_{4}$ exchanges in arctic wetland 
tundra using small plot-scale measurements using chambers (Christensen et al., 2000; Nykanen et al., 2003; Grondahl et al., 2008; Hayne, 2009) and ecosystem-scale measurements using micrometeorological techniques (Friborg et al., 2003; Grondahl et al., 2008). While many studies have been conducted in arctic environments, there is limited knowledge of $\mathrm{C}$ dynamics in Canadian arctic wetland environments. As Canada contains approximately $33 \%$ of the total arctic landmass (Lafleur and Humphreys, 2008), and a vast quantity of $\mathrm{C}$ is found within the top $1 \mathrm{~m}$ of soil, particularly in arctic peatlands, the current magnitude and direction of the $\mathrm{C}$ budget of Canadian arctic peatlands has global implications.

In 1994, a long-term ecosystem monitoring station, the Tundra Ecosystem Research Station (TERS) at Daring Lake, Northwest Territories, Canada (64. $52 \mathrm{~N}$ latitude, $111^{\circ} 34 \mathrm{~W}$ longitude) was established by the Government of Northwest Territories Department of Renewable Resources. In 2004, the Canadian Tundra Ecosystem Carbon Study was established at TERS to monitor exchanges of $\mathrm{CO}_{2}, \mathrm{CH}_{4}$, energy and water vapour between the atmosphere and the tundra. Flux monitoring and manipulation experiments occur annually in order to improve our understanding of the $\mathrm{C}$ cycle of the ecosystems found in this region.

This thesis examines the fluxes of $\mathrm{CO}_{2}, \mathrm{CH}_{4}$, and DOC for a sedge fen, also known as a wet sedge meadow, at Daring Lake during the growing season of 2009. A combination of small plot-scale measurements using chamber systems and ecosystemscale measurements using an eddy covariance system were made to assess the $\mathrm{C}$ budget of the sedge fen and improve our understanding of the biotic and abiotic factors controlling the exchanges of $\mathrm{C}$ for this ecosystem. 
This research will address the following three objectives:

1) To quantify the temporal variation of ecosystem-scale $\mathrm{CO}_{2}$ and $\mathrm{CH}_{4}$ exchanges of a sedge fen at 30 min and day-to-day time scales.

2) To examine the mechanisms controlling both the spatial and temporal exchanges of $\mathrm{CO}_{2}$ and $\mathrm{CH}_{4}$ of this ecosystem.

3) To determine the full growing season $C$ budget of this ecosystem, including the exchange of $\mathrm{CO}_{2}$ and $\mathrm{CH}_{4}$ with the atmosphere and loss of DOC.

More specifically, the following hypotheses will be tested:

1) During the study period, the sedge fen is a $\mathrm{C}$ sink with more $\mathrm{C}$ taken up as $\mathrm{CO}_{2}$ than lost as $\mathrm{CH}_{4}$ and DOC.

2) Temporal and spatial variability in $\mathrm{CO}_{2}$ flux is influenced most by factors that influence photosynthesis such as leaf area, light, and temperature.

3) Temporal and spatial variability in $\mathrm{CH}_{4}$ flux is influenced most by factors that affect anaerobic decomposition such as soil moisture conditions and soil temperatures. 


\subsection{BACKGROUND}

\subsubsection{Arctic Soil Carbon}

In total, northern permafrost regions contain about $1672 \mathrm{Pg}$ of $\mathrm{C}$, which accounts for approximately $50 \%$ of the global below ground organic carbon pool and is more than three times larger than the total global forest $\mathrm{C}$ biomass (Kuhry et al., 2010). $88 \%$ of the northern circumpolar soil organic C stock, or $1466 \mathrm{Pg}$, is found in perennially frozen soils (deeper than the active layer) and deposits (Kuhry et al., 2010). Of the organic $\mathrm{C}$ found in the top $1 \mathrm{~m}$ of soil in permafrost regions $(496 \mathrm{Pg} \mathrm{C})$, northern circumpolar peatlands contain approximately $30 \%$ of the total soil organic carbon (SOC) while covering approximately $19 \%$ of the total area (Tarnocai et al., 2009).

With continued climate warming, this $\mathrm{C}$ pool could become susceptible to decomposition (Post et al., 1982; Bartlett and Harris, 1993; Tarnocai et al., 2009). The C pool has been accumulating over several millennia as the photosynthetic uptake of $\mathrm{CO}_{2}$ exceeds losses of $\mathrm{CO}_{2}, \mathrm{CH}_{4}$, and DOC through decomposition processes. Factors inhibiting decomposition include low temperatures, low quality substrate, and anoxia due to saturated conditions (Davidson and Janssens, 2006). Perma frost thaw could result in the release of large amounts of greenhouse gases $\left(\mathrm{CO}_{2}\right.$ and $\left.\mathrm{CH}_{4}\right)$, due to the remobilization of previously frozen SOC (Schuur et al., 2008). However, as soils warm, concurrent changes in soil moisture, nutrient regimes, and changes in the rate and duration of photosynthetic uptake of $\mathrm{CO}_{2}$ by current and new plant communities will influence to what extent the $\mathrm{C}$ budget of terrestrial arctic ecosystems will change (Schuur et al., 2008). 
The fate of northern $\mathrm{C}$ pools represents one of the most potentially significant carbon-climate feedback effects due to the size of the $\mathrm{C}$ pools and the intensity of high latitude climate warming, and yet, it is one of the least understood of the feedback processes (Schuur et al., 2008).

\subsubsection{Arctic Environment}

Callaghan et al. (2005) define the Arctic tundra as a region above the northern limit of the boreal forest with extreme climate, strong seasonal temperature gradients and a high degree of natural variability. The landscape is snow-covered for most of the year with a short growing season. There are three main types of ecosystems: dry tundra, mesic tundra, and wet tundra which are governed by latitude, climatic, and hydrologic gradients (Welker et al., 2004). Tundra ecosystems are characterized by weakly developed soils, exposed bedrock outcrops, large number of lakes, and a variety of vegetation (grasses, sedges, small flowering herbs, low shrubs, lichens, and mosses) adapted to extreme environments (Bartlett and Harris, 1993). Arctic tundra has been divided between two (Bliss, 1997) and as many as seven (Alexandrova, 1980) subdivisions in the past. For the purpose of this paper, two functional subdivisions, high Arctic tundra and low Arctic tundra (Bliss, 1997) will be defined. According to Walker (2005), the high Arctic tundra consists of mineral soils with very low-stature vegetation (very close to the soil surface), while the low Arctic tundra is composed of peat-rich soils with closed vegetation (shrub and dwarf trees).

Within the arctic landscape, perma frost, defined as subsurface materials that remain at or below $0^{\circ} \mathrm{C}$ for two or more years (Burn and Nelson, 2006), is widespread (Zhang et al., 1999). Permafrost impedes drainage and promotes the formation of 
wetlands (Bartlett and Harris, 1993). Due to the extensive presence of permafrost in the Arctic, peat forming wetlands (peatlands) are widespread and, as defined, must contain a minimum of $40 \mathrm{~cm}$ of peat (Warner and Rubec, 1997). Peatlands store large quantities of C due to anaerobic (lack of oxygen) conditions which slow the breakdown of organic matter (Davidson and Janssens, 2006).

The active layer, defined as the seasonal maximum extent of thaw layer depth (Burn and Nelson, 2006), is primarily controlled by temperature and topo graphy. In the low Arctic, annual active layer depth ranges from $40-80 \mathrm{~cm}$ (ACIA, 2004). Spring snowmelt causes much of the permafrost land surface to be saturated due to the impedance of drainage by permafrost, shallow drainage gradients, and relatively low evapotranspiration rates (Bockheim et al., 1999). Upland areas surrounding low lying areas drain relatively quickly and supply low lying areas with water during the growing season. Water levels in low lying areas may be above, at, or just below the surface. Saturation in these areas causes microtopography differences which may be brought about by frost heave, vegetation differences, decomposition rates, and water movement (Nungesser, 2003)

\subsubsection{Wetland Environment}

There are two main types of peatlands: bogs and fens. Bogs typically have a fluctuating water table at or slightly below the peat surface, nutrients supplied only through precipitation, an acidic $\mathrm{pH}$ of around 3 or 4 , and Sphagnum moss as the dominant flora with the presence of shrubs and sedges (Warner and Rubec, 1997). Fens, in contrast, receive their nutrients from groundwater flow into the wetland, have a fluctuating water table (depending on precipitation, evapotranspiration, and topography), 
and may be characterized by a large variety of vegetation including sedges and grasses and when acidic and nutrient poor, may also have Sphagnum moss (Warner and Rubec, 1997).

Wetland surfaces are not commonly uniform. Many wetlands have relatively dry, elevated mounds (tussocks or hummocks) rising from low-lying, generally saturated areas (lawns or hollows) (Nungesser, 2003; Lai, 2009). Tussocks can range in height from several centimeters up to a meter and are generally oval but can be circular; while, low-lying saturated areas can either be in the form of open, flat small spaces between tussocks or large flat lawn areas or saturated pools (Nungesser, 2003). Microtopography within wetland environments has been found to remain relatively unchanged over centuries to millennia and general agreement indicates that tussocks and lawns maintain themselves indefinitely (Barber, 1981); however, the mechanisms which contro1 formation and control over time are not well understood (Nungesser, 2003). Johnson and Damman (1991) infer that morphological differences between tussocks and lawns are caused by varying decomposition rates. Some studies suggest that Sphagnum species within tussocks decay at a slower rate and retain their physical structure longer than those within hollows, indicating that peat accumulates at a higher rate within tussocks (Johnson and Damman, 1991; Ohlson and Dahlberg, 1991). However, Nungesser (2003) argues that there is no single factor that can determine the growth and resilience of tussock and lawn microtopography; rather, it is likely that a covariance between moisture, Sphagnum growth and decay, and peat accumulation that dictates the overall morphology of a wetland through time. 


\subsection{Fluxes of $\mathrm{CO}_{2}, \mathrm{CH}_{4}$, and DOC}

Fluxes of $\mathrm{C}$ in arctic wetland ecosystems are dominated by atmospheric exchanges of $\mathrm{CO}_{2}$ and $\mathrm{CH}_{4}$ and the loss of DOC. As global warming continues, $\mathrm{CO}_{2}$ and $\mathrm{CH}_{4}$ production associated with accelerated decomposition processes (with warmer soil temperatures) represent the dominant pathways through which this stored $\mathrm{C}$ may be released to the atmosphere (Christensen, 1995). Warming could also increase active layer depth in perma frost soils and facilitate the export of previously frozen DOC to other ecosystems and eventually to water bodies where it is used as a food source for bacteria, resulting in greater $\mathrm{CO}_{2}$ emissions to the atmosphere (Bushaw et al., 1996). Warming could result in negative effects on freshwater ecosystems, altering the timing and concentration of DOC flux (Bushaw et al., 1996; Shindler and Curtis, 1997; Gergel et al., 1999) which controls aquatic microbial diversity, productivity, biogeochemical cycles, and attenuation of ultra violet and visible radiation, impacting overall water quality (Pastor et al., 2003; Waldron et al., 2008).

For relatively dry soils, $\mathrm{CO}_{2}$ is the dominant greenhouse gas exchanged between terrestrial ecosystems and the atmosphere. In moist, anaerobic soils, such as wetlands and peatlands, $\mathrm{CH}_{4}$ exchange may be significant. In view of atmospheric warming, $\mathrm{CH}_{4}$ has a 72 -fold (over 20 years) greater warming effect on the atmosphere per gram than that of $\mathrm{CO}_{2}$. Therefore, it is important to quantify both gas fluxes in order to determine the greenhouse warming potential (GWP) of an ecosystem (Friborg et al., 2003). GWP is defined as the time-integrated radiative forcing of a gas over a given period relative to the same amount of $\mathrm{CO}_{2}$ over that period (IPCC, 2007). However, it is important that the appropriate 'period' be used to assess the GWP of an ecosystem. While $\mathrm{CO}_{2}$ is relatively 
stable in the atmosphere, $\mathrm{CH}_{4}$ denatures comparatively quickly. Consequently, the greenhouse gas inventory for an ecosystem should be evaluated over an ecosystem's lifetime, which for wetlands, may be several thousand years (Frolking et al, 2006).

While there have been studies that have investigated $\mathrm{CO}_{2}$ and $\mathrm{CH}_{4}$ fluxes in arctic ecosystems (Vourlitis and Oechel, 1999; Christensen et al., 2000; La fleur and Humphreys, 2008; Willie et al., 2008), these studies either employed the use of chambers $\left(<1 \mathrm{~m}^{2}\right)$ to assess the $\mathrm{C}$ budget or only measured $\mathrm{CO}_{2}$ or $\mathrm{CH}_{4}$ exchange at an ecosystem scale (up to $\sim 1 \mathrm{~km}^{2}$ ) using micrometeorological techniques. At present, there have been very few studies that have facilitated direct comparison of the combined greenhouse forcing effects of these two gases from natural ecosystems (Friborg et al., 2003). While chamber techniques have been used to assess $\mathrm{CO}_{2}$ and $\mathrm{CH}_{4}$ fluxes within arctic ecosystems, the accuracy of upscaling these measurements to the ecosystem scale is uncertain due to the spatial and temporal variability of biotic and abiotic factors (Riutta et al., 2007; Willie et al., 2008). Therefore, there exists a need for ecosystem-scale measurements of both $\mathrm{CO}_{2}$ and $\mathrm{CH}_{4}$ flux within arctic environments in order to accurately determine the flux of $\mathrm{C}$ to the atmosphere. In addition, there also exists a need to assess the DOC budget of many of these ecosystems. DOC can play a pivotal role in assessing the $\mathrm{C}$ sink/source status of an ecosystem (Strack et al., 2008)

Eddy covariance and chamber techniques are two well established methods to determine trace gas flux at the ecosystem and small plot scales, respectively. The primary advantage of the chamber technique is the ability to enclose small areas of an ecosystem in order to investigate the influence of small scale variations in ecosystem characteristics (e.g. plant composition, soil characteristics, microtopo graphy, etc) on 
fluxes. However, for non-automated versions, the measurements must be made manually such that only a small sample size in time and space is obtained, the equipment can be heavy and cumbersome to carry in remote areas, and the operator and the chamber itself disturbs the ecosystem by iso lating it from the surrounding atmosphere such that light, gas concentrations, temperature and humidity do not remain at ambient conditions during a measurement. The primary benefits of the eddy covariance technique include instantaneous measurements of fluxes continuously for a measurement period at the ecosystem scale. However, for the eddy covariance technique to provide meaningful measures of biotic fluxes, relatively level and homogeneous terrain is required.

\subsection{1 $\mathrm{CO}_{2}, \mathrm{CH}_{4}$, and DOC Cycling}

\subsubsection{1 $\mathrm{CO}_{2}$ Flux}

Net ecosystem exchange of $\mathrm{CO}_{2}$ (NEE) is the difference between photosynthetic uptake of $\mathrm{CO}_{2}$ and the emission of $\mathrm{CO}_{2}$ through respiration within an ecosystem Gross ecosystem production (GEP) is the rate of photosynthetic uptake of $\mathrm{CO}_{2}$ by plants. Ecosystem respiration (ER) is defined here as the production of $\mathrm{CO}_{2}$ through several biochemical processes. Aerobic respiration, oxidation of $\mathrm{CH}_{4}$, and anaerobic fermentation of glucose to organic acids all result in the formation of $\mathrm{CO}_{2}$ (Luo and Zhou, 2006). ER can be divided into two main components, autotrophic respiration (plant respiration) $\left(E R_{a}\right)$ and heterotrophic respiration (microorganism respiration) $\left(E R_{h}\right)$, such that $\mathrm{ER}$ is equal to the sum of both $\mathrm{ER}_{\mathrm{a}}$ and $\mathrm{ER}_{\mathrm{h}}$ for a given period. The metabolic process of plant functioning controls $\mathrm{ER}_{\mathrm{a}}$; as such, it is strongly related to plant productivity. Plant growth is influenced by such abiotic factors as temperature, nutrient and moisture availability, and photosynthetically active radiation (PAR). $E R_{h}$ is 
controlled by substrate availability and quality, temperature, and moisture characteristics of the soil (Elberling, 2007). Anoxic conditions, low temperatures, small microbial populations, and high refractory content of litter causes low decomposition rates in northern peatlands (Moore and Basiliko, 2006) resulting in $\mathrm{CO}_{2}$ accumulation rates of 76 Tg C y $\mathrm{y}^{-1}$ globally (Gorham 1991).

\subsubsection{2 $\mathrm{CH}_{4}$ Flux}

The cycling of $\mathrm{CH}_{4}$ in peatlands involves numerous biogeochemical processes which are controlled by various chemical, physical, and biological factors (Kutzbach et al., 2004; Lai, 2009). Production of $\mathrm{CH}_{4}$ in northern peatlands results in approximately

$46 \mathrm{Tg} \mathrm{CH}_{4}-\mathrm{C}^{-1}$ released to the atmosphere (Gorham, 1991), which is equivalent to $12.2 \%$ of global input (Wuebbles and Hayhoe, 2002). Net contribution of wetland $\mathrm{CH}_{4}$ to the atmosphere is the difference between production and oxidization of $\mathrm{CH}_{4}$ in the anoxic and oxic regions.

Whalen (2005) describes the two main ways in which $\mathrm{CH}_{4}$ is generated as a metabolite by methanogens $\left(\mathrm{CH}_{4}\right.$ producing microbes) during energy production in anaerobic conditions. Acetate substrate $\left(\mathrm{CH}_{3} \mathrm{COOH}\right)$ is used by acetotrophic methanogens to produce $\mathrm{CH}_{4}$ and $\mathrm{CO}_{2}$ and is known as acetoclastic methanogenes is. Hydrogen gas $\left(\mathrm{H}_{2}\right)$ and $\mathrm{CO}_{2}$ are used by hydrogenotrophic methanogens during the reduction process to produce $\mathrm{CH}_{4}$ and water. Generally, acetoclastic methanogenesis occurs in upper peat layers where decomposition of fresh root litter and root exudates are the predominate source of energy for microorganisms. In lower peat layers, where organic material is recalcitrant (resists bioactivity), $\mathrm{H}_{2}$ and $\mathrm{CO}_{2}$ methanogenesis predominates (Hornibrook et al., 1997). 
Oxidation of $\mathrm{CH}_{4}$ by methanotrophs in the aerobic zones may occur after $\mathrm{CH}_{4}$ production through methanogenesis in underlying anaerobic peat layers. Methanotrophic activity occurs as high affinity oxidation, primarily at $\mathrm{CH}_{4}$ concentrations close to atmospheric values, and as low affinity oxidation, dominant in northern peatlands where $\mathrm{CH}_{4}$ concentrations are very high (Segers, 1998). Methanotrophs at low affinity break the oxygen molecule $\left(\mathrm{O}_{2}\right)$ into oxygen atoms $(\mathrm{O})$ and form water $\left(\mathrm{H}_{2} \mathrm{O}\right)$ and methanol $\left(\mathrm{CH}_{3} \mathrm{OH}\right)$. Methanotrophy generally reaches peak rates at the interface between anaerobic and aerobic zones where the ratio of oxygen to substrate $\mathrm{CH}_{4}$ is favorable (Dedysh, 2002). Water tables near or at the surface minimize the potential for $\mathrm{CH}_{4}$ oxidation, while water tables at depth allow for greater methanotrophic activity and reduce net emissions of $\mathrm{CH}_{4}$. Segers (1998) found that the potential for $\mathrm{CH}_{4}$ oxidation is approximately an order of magnitude greater than that of $\mathrm{CH}_{4}$ production. Therefore, the consumption and release of $\mathrm{CH}_{4}$ relates to transport to and through zones of oxidation

There are three main pathways by which $\mathrm{CH}_{4}$ may reach the atmosphere from production zones in peatlands: diffusion, ebullition, and plant mediated transport (Lai, 2009). A concentration gradient generally develops between the saturated anaerobic zone of $\mathrm{CH}_{4}$ production and the unsaturated aerobic zone of $\mathrm{CH}_{4}$ oxidation. As such, this concentration gradient drives the mo lecular diffusion of $\mathrm{CH}_{4}$ to the surface. Diffusive flux is considerably slower than the other two mechanisms, yet provides the necessary contact of $\mathrm{CH}_{4}$ with the methanotrophic community, ultimately controlling the rate of $\mathrm{CH}_{4}$ oxidization (Whalen, 2005). Ebullition releases $\mathrm{CH}_{4}$ to the atmo sphere when supersaturation occurs at very high rates of methanogenesis deep in the pore water of anaerobic peat layers. Ebullition occurs when the partial pressure of gases in solution are 
greater than the hydrostatic pressure of peat (Chanton and Whiting, 1995). The bubbles attach to pore walls by adhesive forces until they grow in size and their pressure is greater than the forces of attraction, resulting in gas bubble ejection. Ebullition is caused by atmospheric pressure drop, reduction in hydrostatic pressure, or a rise in temperature (Strack et al., 2005; Tokida et al., 2007). Tokida et al. (2007) found in a northern peatland that ebullition accounted for approximately 50 to $65 \%$ of total $\mathrm{CH}_{4}$ flux. Plant mediated transport of $\mathrm{CH}_{4}$ may also occur through the presence of aerenchyma tissue found in vascular plants such as Carex spp. (Bellisario et al., 1999; Strom et al., 2003, Strack et al., 2004). The primary function of aerenchyma tissue is to deliver oxygen to submerged organs in anoxic peat below the water table; however, at the same time, they can serve as direct conduits for $\mathrm{CH}_{4}$ in the root zone to flow to the atmosphere, bypassing the methane-oxidizing, aerobic peat layers (Whalen, 2005). The two primary mechanisms in plant-mediated transport of $\mathrm{CH}_{4}$ are molecular diffusion and bulk flow. Many studies involving aerenchyma adapted vascular vegetation such as sedges have found increased rates of $\mathrm{CH}_{4}$ emission relative to sites without sedges or with sedge removal (Whalen and Reeburgh, 1990; Canton and Whiting, 1992; Torn and Chapin, 1993; King et al., 1998).

Temporal and spatial variation in $\mathrm{CH}_{4}$ flux is attributed to variation in water table depth (WT), air and soil temperature, peat acidity, vegetation type, and plant productivity (NPP) (Lai, 2009). Segers (1998) a lso suggests that an important control on methanogenesis is the supply of organic substrate once anaerobic conditions are established in peat layers. In addition to organic substrate, soil temperature and WT interact strongly to influence the production and oxidation of methane (Granberg et al., 
1997). With a high water table near or at the surface, increases in temperature at depth in the anaerobic zone will result in increased methane production and emission; however, when the water table decreases below the surface, and the zone of oxidation increases, temperature in the oxic zone has an increasing influence to temperatures in the anoxic zone on methane production and emission (Granberg et al., 1997). In addition, as the anaerobic zone decreases from the surface, temperatures within this zone will also decrease, limiting the potential for greater methane production (Granberg et al., 1997). Therefore, increases in temperature at depth will influence the production of methane; however, it is strongly related to changes in water table.

\subsubsection{DOC Flux}

DOC is defined as small (less than $0.45 \mu \mathrm{m}$ in diameter) organic material (Wangersky, 1993). Dissolved inorganic carbon (DIC) is defined as the total amount of inorganic carbon within a solution and refers to $C$ supplied by carbonate sources (Worrall et al., 2003), including $\mathrm{CO}_{2}$, carbonic acid, bicarbonate anion, and carbonate (Schumacher, 2002). Temperature, soil moisture, soil solution chemistry, vegetation community and site hydrology have all been found to play an integral role in influencing DOC concentrations and fluxes (Moore et al., 1998; Kalbitz et al., 2000; Strack et al., 2008). Many studies conclude that the major factor controlling DOC flux is storm events which cause large amounts of water to flow through the soil and over land (Waddington and Roulet, 1997; Clark et al., 2007; Pawson et al., 2008; Strack et al., 2008). However, Clark et al. (2007) suggests that ultimately DOC is controlled by discharge volume which is a function of the topography of the wetland and the surrounding area, precipitation in the form of rain and snow, and snow melt. Boreal peatland studies in Sweden have shown 
that DOC loss via groundwater movement can account for up to 10 times the amount of lost via $\mathrm{CH}_{4}$ emissions to the atmosphere (Waddington and Roulet, 1996). Waddington and Roulet (1997) found that the total mass flux of DOC accounted for approximately $20 \%$ of $\mathrm{CO}_{2}$ fixation. While, Fraser et al. (2001) found in a northern ombrotrophic peatland that DOC flux was equal to $12 \%$ of the $\mathrm{C}$ stored through NEE and between 28 to $48 \%$ of sequestered long-term C; DOC flux from northern peatlands ranges from 1 to 48 $\mathrm{g} \mathrm{C} \mathrm{m}^{-2} \mathrm{y}^{-1}$; however, in arctic areas, where catchments are dominated by peat, relief is negligible, and precipitation is equal to evapotranspiration, DOC flux measurements tend to be smaller (i.e. less than $10 \mathrm{~g} \mathrm{C} \mathrm{m}^{-2} \mathrm{y}^{-1}$ ) (Fraser et al., 2001).

\subsubsection{Carbon B udget Studies}

There have been many northern studies that have investigated some aspect of ecosystem/watershed-scale $\mathrm{CO}_{2}, \mathrm{CH}_{4}$, or DOC exchange in the Arctic (Waddington and Roulet, 1997; Griffis et al., 2000; Lafleur et al., 2001; Friborg et al., 2000; Friborg et al., 2003; Lafleur and Humphreys, 2008; Fox et al., 2008; Willie et al., 2008); however, there has only been one study that the author is aware of that concurrently measured $\mathrm{CO}_{2}$ and $\mathrm{CH}_{4}$ exchange at the ecosystem scale (Friborg et al., 2003), and to the author's knowledge, there have not been any studies that directly relate $\mathrm{CO}_{2}, \mathrm{CH}_{4}$, and DOC to the total $\mathrm{C}$ budget of an arctic ecosystem. There have been a few studies that have related all three components of the $\mathrm{C}$ budget within non-arctic peatland ecosystems (e.g. Worrall et al., 2003, Roulet et al., 2007). Results from studies in the Arctic indicate that $\mathrm{CO}_{2}$ and $\mathrm{CH}_{4}$ flux shows great spatial variability within plot-to-plot comparisons in the same ecosystem with regard to sink/source magnitude (Christensen et al., 2000; Corradi et al., 2005). Some studies have also shown that inter-annual variability in $\mathrm{CO}_{2}$ fluxes can 
result in net $\mathrm{C}$ release one year and a $\mathrm{C}$ sink the next (Oechel et al., 1993, Vourlitis and Oechel, 1999; Oechel et al., 2000) with the possibility that the change between sink/source status may be due to a variety of environmental conditions brought about by natural inter-annual climate variability.

Christensen et al. (2000) found in certain northern wetland and tundra environments that $\mathrm{CO}_{2}$ and $\mathrm{CH}_{4}$ fluxes are influenced by soil saturation, temperature, active layer depth, growing season length, topography, and plant species. Many studies conclude that there is no one single environmental variable that governs the flux of $\mathrm{CO}_{2}$ and $\mathrm{CH}_{4}$ (Whalen et al., 1992; Bartlett and Harris, 1993; Torn and Chapin, 1993; Bubier and Moore, 1994). Climate change is expected to influence all of these variables, such that it is possible that some arctic ecosystems may change from an annual sink of $\mathrm{C}$ to a source of (Vourlitis and Oechel, 1999; Oechel et al., 2000; Friborg et al., 2003; Lafleur and Humphreys, 2008) with important consequences to the global C budget. Fluxes of $\mathrm{CO}_{2}, \mathrm{CH}_{4}$, and DOC can all play an important role in determining the overall $\mathrm{C}$ sink/source strength of a system. There remains uncertainty regarding the current magnitude of $\mathrm{CO}_{2}, \mathrm{CH}_{4}$, and DOC fluxes for arctic wetlands. Although much is known regarding the environmental controls which affect these $\mathrm{C}$ fluxes at varying spatial and temporal scales, there remains uncertainty regarding their effects on the spatial and temporal variations in the $\mathrm{C}$ budget of arctic peatland ecosystems. Further estimates of the current $C$ budgets of these ecosystems and how they respond to variations in temperature and moisture will help improve our understand ing of important terrestrial surface-atmosphere feedbacks to the climate system. 


\subsection{METHODS}

\subsection{Site Description}

The field study site is located close to Daring Lake, central Northwest Territories, Canada $\left(64^{\circ} 52^{\prime} \mathrm{N}, 111^{\circ} 34^{\prime} \mathrm{W}\right)$ at TERS, approximately $70 \mathrm{~km}$ above the tree line and $300 \mathrm{~km}$ northeast of Yellowknife within the Southern Arctic Ecozone. The research area is located in a sedge fen approximately $1 \mathrm{~km}$ from the TERS (Figure 1). Research was conducted in collaboration with the Canadian Tundra Ecosystem Carbon Study at Daring Lake, established in 2004 to investigate the magnitude of and controls on $\mathrm{C}$ fluxes within these tundra ecosystems (Lafleur and Humphreys, 2008).

The climate is characterized as having short, snow-free, growing seasons with mean monthly temperatures above $0^{\circ} \mathrm{C}$ from June through September. The growing season typically spans mid June to early September. The mean annual temperature is -13 ${ }^{\circ} \mathrm{C}$ and precipitation varies from $200-400 \mathrm{~mm}$ (Lafleur and Humphreys, 2008; Natural Resources Canada, 2009). The area has a shallow seasonal active layer between $0.3-1.2$ m deep, with variation in depth depending on soil type and vegetation, and is underlain by continuous permafrost to a depth of $>160 \mathrm{~m}$ (Dredge et al., 1999). The period from May 15 to Aug 312009 had an average air temperature of $6.5^{\circ} \mathrm{C}$ and $80.9 \mathrm{~mm}$ of rain, making 2009 slightly cooler and drier than the average of $8.4^{\circ} \mathrm{C}$ and $103.7 \mathrm{~mm}$ recorded at the site over the same dates from 1997 to 2005 (Lafleur and Humphreys, 2008). 


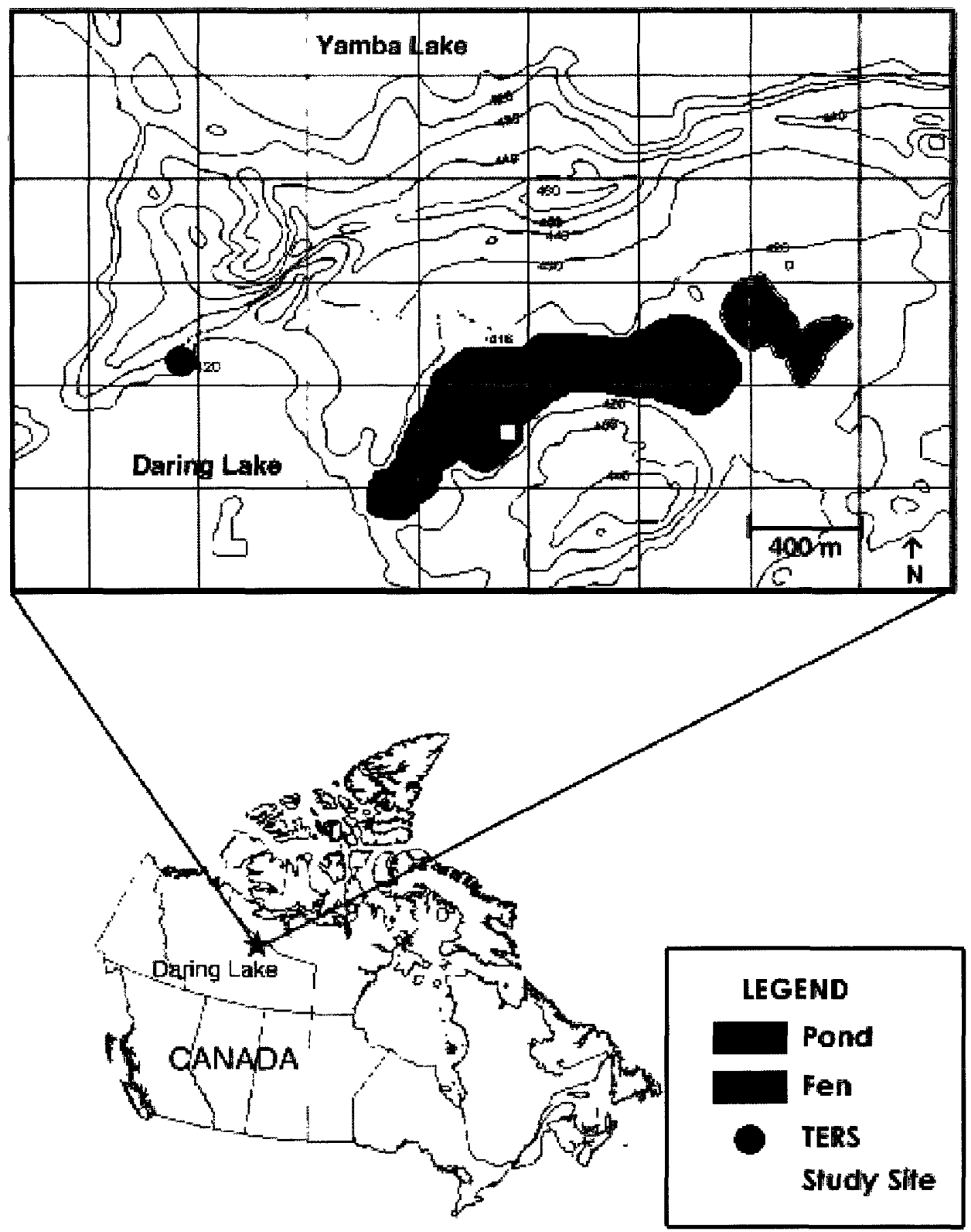

Figure 1. Map of the research area at Daring Lake, NT with the location of the Tundra Ecological Research Station (TERS), fen and study site (Adapted from Nobrega and Grogan, 2008). 
The roughly 48 ha sedge fen where the study took place lies along the bottom of a shallow $\sim 1.5 \mathrm{~km}$ long by $1.0 \mathrm{~km}$ wide valley, draining into Daring Lake. The age of the fen is approximately $1920 \pm 80 \mathrm{yrs}$ before present (Okolo, 2008). The fen includes a variety of vegetation communities (Figure 2) including raised peat mounds with dwarf birch (Betula glandulosa) but is dominated by lawns and tussocks populated by sedges (Carex spp., Eriophorum spp.), bog rosemary (Andromeda polifolia), and a nearly continuous ground cover of moss (Sphagnum spp.) (Figure 3). For the tussock and lawn communities, peak LAI of all vascular plants was $0.80( \pm 0.04 \mathrm{SE})$ as determined using the point frame method. Peak vascular LAI determined using the LAI-2000 Plant Canopy Analyzer (LI-COR Inc., Lincoln, NB, USA) was similar at $0.66( \pm 0.15)$. The fen soil consisted of a layer of peat varying from approximately $40 \mathrm{~cm}$ (lawns) to $60 \mathrm{~cm}$ (tussocks) over silt loam mineral soil (Table 1) (Hayne, 2009), and completely freezes during the winter season. By mid August 2009, the peat layer had thawed with a maximum thaw depth of $47.4( \pm 0.8) \mathrm{cm}$ and $62.4( \pm 0.8) \mathrm{cm}$ for the lawn and tussock communities. 

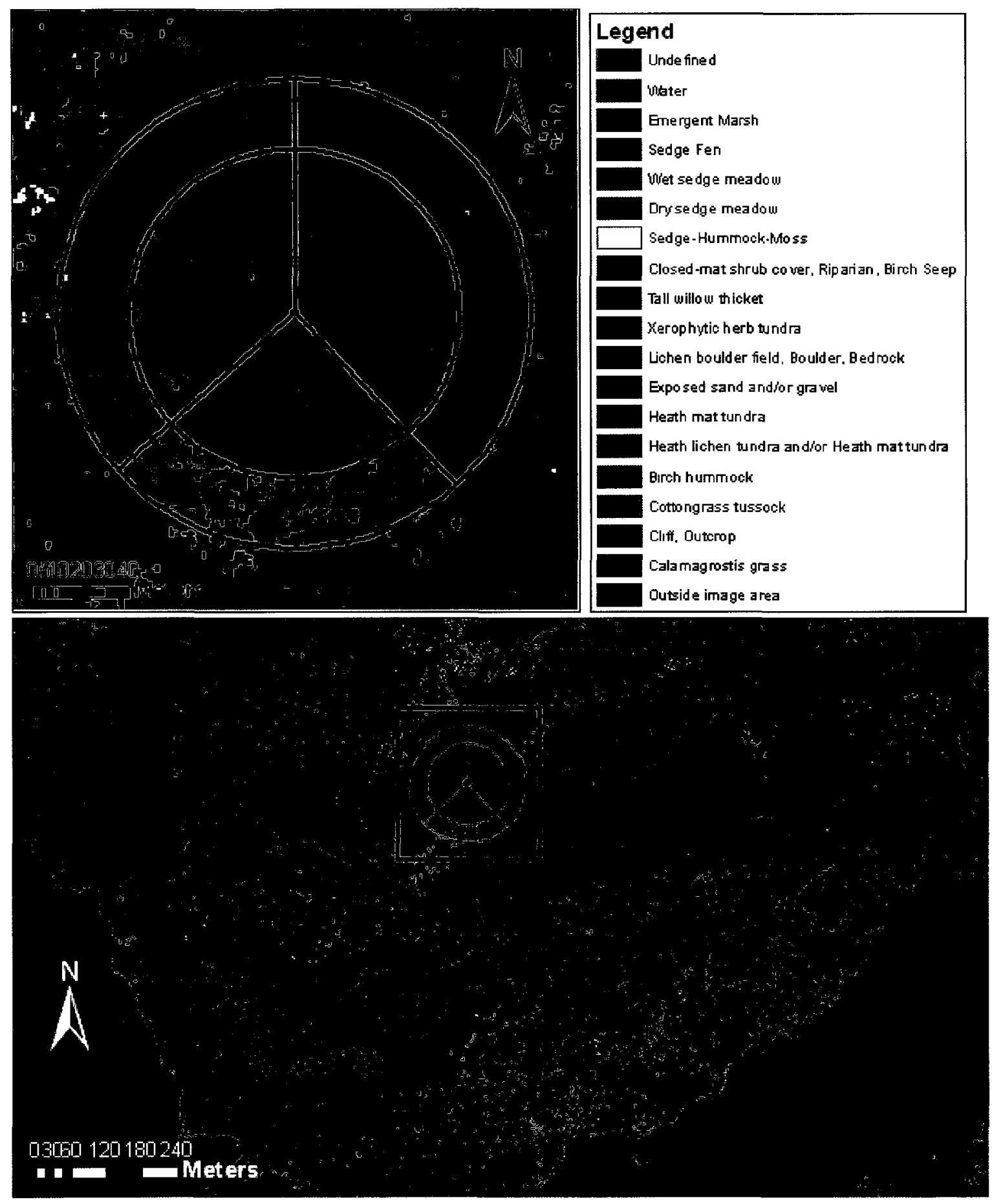

Figure 2. Vegetation map (edited from Obst, 2008) showing the location of micrometeoro logical tower within the wet fen at Daring Lake, NT. Inner ring represents radius of $70 \mathrm{~m}$ and outer ring a radius of $100 \mathrm{~m}$. Three sectors are delineated: $0^{\circ}-135^{\circ}$ (sedge fen dominated by lawn topography to NE, rocky upland area to SE); $135^{\circ}-225^{\circ}$ (sedge fen with tussock topography, small, open water bodies and rocky upland area); $225^{\circ}-360^{\circ}$ (sedge fen and shrub peat mound areas). 

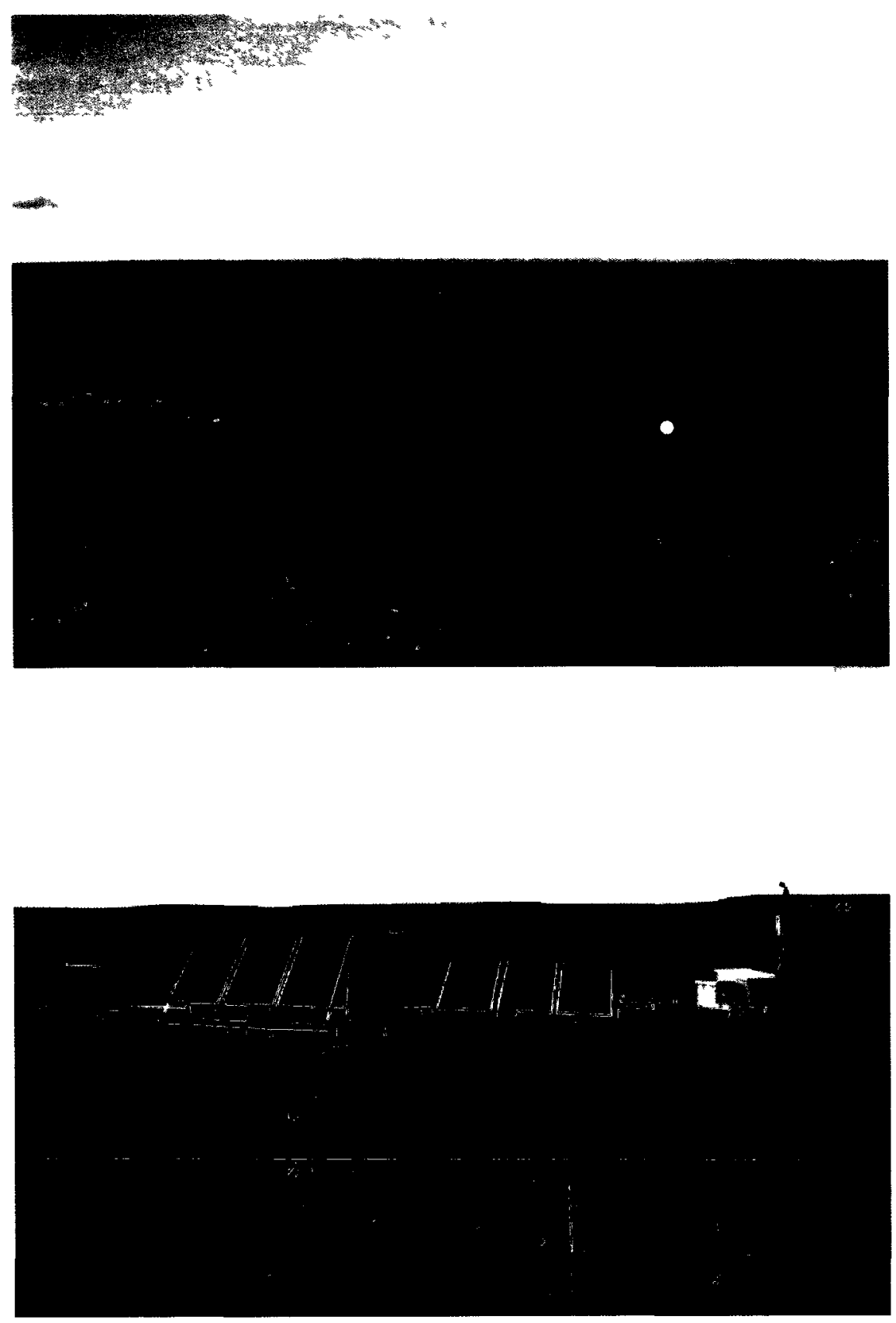

Figure 3. Top panel- NE aerial view of Darling Lake, NT including Yamba Lake in top left. Yellow circle gives approximate location of micrometeorological tower. Bottom pane1-Micrometeorological setup with a view to the north. Lawn and tussock topography is shown in foreground. 


\subsection{Experime ntal Design}

Both micrometeorological and chamber techniques were used to quantify $\mathrm{CO}_{2}$ and $\mathrm{CH}_{4}$ exchange between the fen and the atmosphere during a period from July $11^{\text {th }}$ (DOY 192 ) to August $15^{\text {th }}$ (DOY 227) 2009. The eddy covariance (EC) technique was used to measure ecosystem-scale $\mathrm{C}$ fluxes on a continuous basis while chamber measurements were made to investigate small scale spatial variations in these exchanges. In order to determine the relationships between ecosystem $\mathrm{CO}_{2}, \mathrm{CH}_{4}$, and environmental variables (biotic and abiotic), we needed continuous measurements (30 minute averages) of wind velocity and direction, air and soil temperature and moisture, photosynthetically active radiation, and water table depth. In order to determine the relationships between $\mathrm{CO}_{2}$ and $\mathrm{CH}_{4}$, microtopography, and environmental variables at the small plot-scale, we needed to measure air and soil temperature and moisture, photosynthetically active radiation, leaf area index, species composition and distribution, and thaw layer depth at the same time as $\mathrm{CO}_{2}$ and $\mathrm{CH}_{4}$ measurement. The EC tower (Figure 3) was located at $64^{\circ} 51^{\prime} 52^{\prime \prime} \mathrm{N}$ and $111^{\circ} 33^{\prime} 59^{\prime \prime} \mathrm{W}$ (NAD 27) approximately $100 \mathrm{~m}$ from the southern edge of the fen (Figure 2). Sixteen permanent collars were installed along a boardwalk within the fetch of the micrometeorological tower (Figure 4). The permanent locations of the 16 collars were assigned randomly along the boardwalk at the beginning of the study period. Eight collars (PVC SDR-35 sewer pipe inner diameter $29.5 \mathrm{~cm}$ and an area of $683.5 \mathrm{~cm}^{2}$ ) were installed in lawn (L) and tussock (T) communities. The lawn collars were $12 \mathrm{~cm}$ tall and inserted $5 \mathrm{~cm}$ into the soil to form a good seal with the surround ing saturated peat. The tussock collars were $20 \mathrm{~cm}$ tall and inserted approximately $15 \mathrm{~cm}$ to reach a depth that was generally saturated in order to prevent diffusion of $\mathrm{CO}_{2}$ and $\mathrm{CH}_{4}$ gas from the bottom 
of collar. A knife was used to cut into the peat around the collar exterior and the vegetation was guided up through the centre of the collar before insertion. All collars had a groove in the top rim which was filled with water to form a seal between the chamber and the collar during sampling to minimize gas leaks.

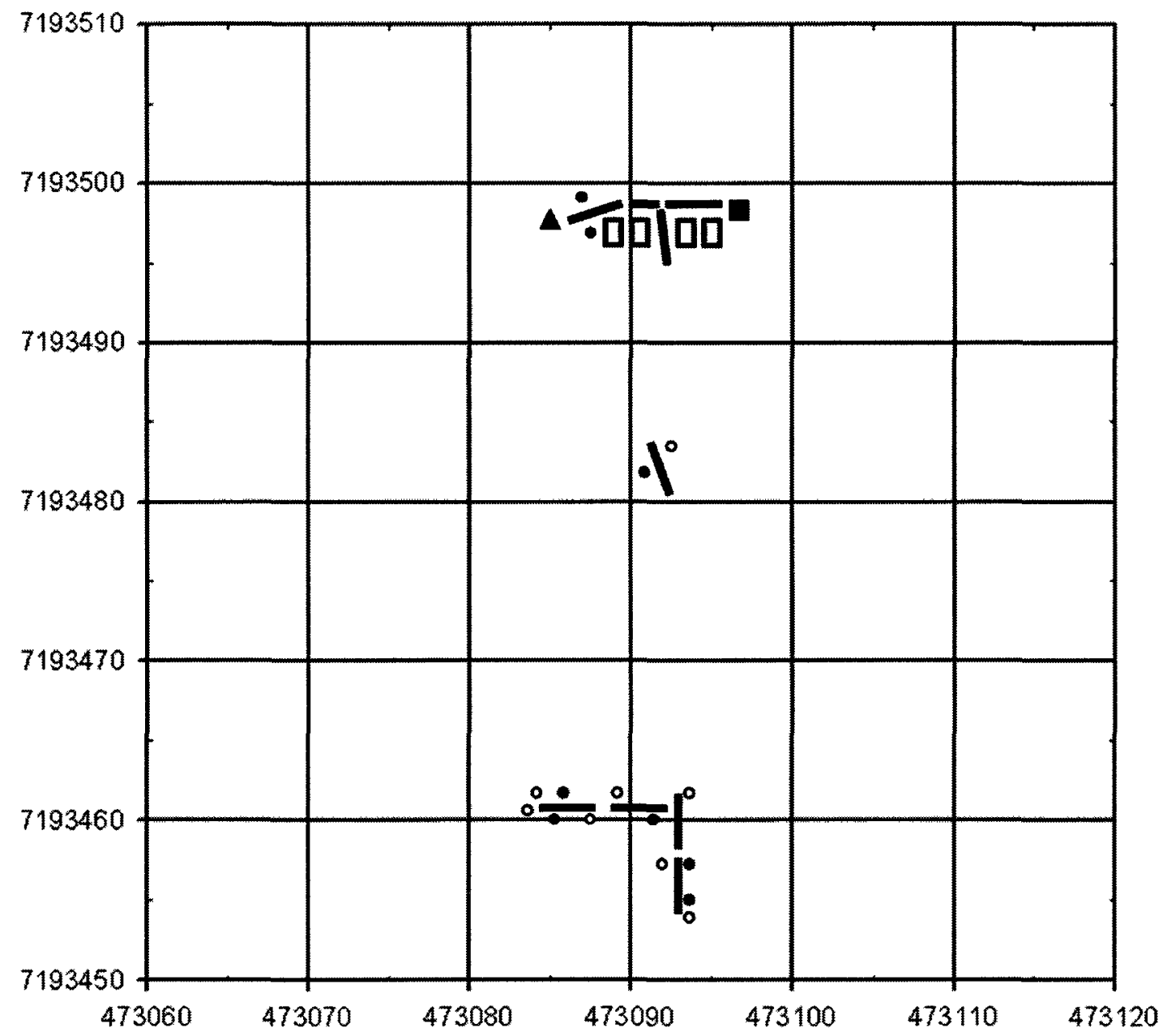

Figure 4. P lot locations of 16 permanent collars installed at Daring Lake, NT, 2009. Closed circles represent lawns and open circles represent tussocks. The closed black square represents micrometeorological tower, open squares represent solar panels, and closed triangle represents the generator. UTM coordinate system in Easting and Northing, Map 12N (North America). Locations are within 2 meter accuracy. 


\subsection{Data collection}

\subsubsection{NEE Chamber System}

NEE was measured using a portable, closed, flow-through, non-steady state chamber system. The system consisted of the collar, a clear acrylic chamber lid ( 0.0197 $\mathrm{m}^{3}$ ) connected by tubing to an external infrared gas analyzer (IRGA) (LI-840, LI-COR Inc., Lincoln, NB, USA) via a pump. NEE was measured by sealing the chamber to the collar and measuring the change in $\mathrm{CO}_{2}$ and $\mathrm{H}_{2} \mathrm{O}$ concentrations within the chamber volume over a $2 \mathrm{~min}$ interval. In order for a relationship between NEE, light and temperature to be achieved, NEE was measured under four different light levels: full light using a clear, uncovered chamber, partial shade using a layer of $50 \%$ shading cloth over the chamber, more shade using two layers of $50 \%$ shading cloth, and opaque conditions using a heavy duty black plastic garbage bag over the chamber. Under opaque conditions, ecosystem respiration of $\mathrm{CO}_{2}\left(\mathrm{ER}_{\mathrm{F}}\right)$ was measured; while, gross ecosystem production $\left(\mathrm{GEP}_{\max }\right)$ was estimated as the difference between full light $\mathrm{NEE}\left(\mathrm{NEE}_{\max }\right)$ and $\mathrm{ER}_{\mathrm{F}}$ measurements. Incoming photosynthetica lly active radiation $(\mathrm{PAR})$ was measured using a quantum sensor (model LI-190, LI-COR Inc., Lincoln, NB, USA) mounted upon a tripod and subjected to the same shading conditions as the chamber. PAR received by the vegetation within the chamber was adjusted to $92 \%$ of sensor PAR to account for attenuation caused by the clear acrylic of the chamber (Kim et al., 2004). Mounted within the chamber was a mixing fan, which continually mixed air within the chamber to prevent a concentration gradient from developing at the top of the chamber lid, a Peltier cooler, which was activated if chamber temperature elevated above ambient air temperature by $2{ }^{\circ} \mathrm{C}$ to maintain near ambient conditions, and a fine-wire 
thermocouple, which measured the air temperature within the chamb er. Bev-a-line inflow and outflow tubing were attached to the chamber lid and connected to the portable IRGA system. A pump circulated air in the system at $2 \mathrm{~L} \mathrm{~min}^{-1}$ with a subsample of air drawn into the IRGA at $0.7 \mathrm{~L} \mathrm{~min}^{-1}$. A CR23X data logger (Campbell Scientific, Inc., Edmonton, $\mathrm{AB}, \mathrm{Canada}$ ) recorded date, time, $\mathrm{CO}_{2}$ and $\mathrm{H}_{2} \mathrm{O}$ concentrations, air temperature, and PAR at $1 \mathrm{~Hz}$. The system was powered by a $12 \mathrm{~V}$ battery. All data was downloaded and stored on a computer at the end of each sampling day.

NEE measurements were made on days when incoming PAR was on average greater than $700 \mu \mathrm{mol} \mathrm{m}^{-2} \mathrm{~s}^{-1}$. This allowed for a light response curve to be developed in relation to NEE, PAR, and T. During the 2009 field campaign, measurements on all collars were carried out on 13 days. The sampling order of 16 collars was randomized each day.

\subsubsection{Opaque Chamber System}

Static opaque chambers $\left(0.0219 \mathrm{~m}^{3}\right)$ were used to measure respired $\mathrm{CO}_{2}\left(\mathrm{ER}_{\mathrm{S}}\right)$ and $\mathrm{CH}_{4}$ exchange in dark conditions which prevents the fixation of $\mathrm{CO}_{2}$ through photosynthesis. These measurements were made by sealing a simple acrylic chamber to the collar and measuring the change in $\mathrm{CO}_{2}$ and $\mathrm{CH}_{4}$ concentration within the chamber volume over a 20 min interval. During this time, gas samples were taken at $0,5,10,15$, and $20 \mathrm{~min}$. First, a $60 \mathrm{ml}$ syringe connected by Bev-a-line tubing to the chamber was manually pumped $4-5$ times to mix the chamber air before withdrawing a $27 \mathrm{ml}$ sample from a septa attached to a 3-way stopcock. The gas sample was then injected into a preevacuated vial(Labco International Inc., Houston, TX, USA). Vials contained small amounts of magnesium perchlorate, a desiccant, to remove any moisture within the 
sample. The gas samples were stored up to 2 months and transported to Carleton University's Biometeorology laboratory where $\mathrm{CH}_{4}$ and $\mathrm{CO}_{2}$ concentrations were determined using a gas chromatograph (CP 3800, Varian, CA, USA). The gas chromatograph was equipped with a methanizer and flame-ionization detector (FID) operating at $350{ }^{\circ} \mathrm{C}$ and $300{ }^{\circ} \mathrm{C}$, respectively, both using helium carrier gas at a rate of 30

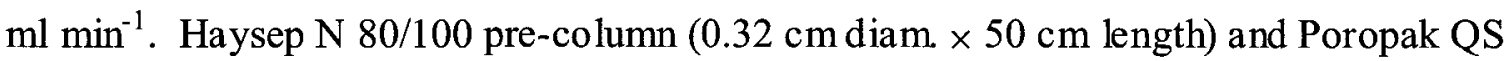
$80 / 100$ mesh analytical columns $(0.32 \mathrm{~cm}$ diam. $\times 200 \mathrm{~cm}$ length $)$ were used in the column oven maintained at $50^{\circ} \mathrm{C}$ to achieve gas separation from the samples. Three replicates of 5 standard gas concentrations (between 439.2 and $15212.6 \mathrm{ppm}$ for $\mathrm{CO}_{2}$ and between 1.08 and $19.94 \mathrm{ppm}$ for $\mathrm{CH}_{4}$ along with $\mathrm{He}$ blanks) were used to maintain quality control and establish a linear relationship between gas concentrations and chromatogram area (Hayne, 2009).

$\mathrm{ER}_{\mathrm{S}}$ measurements were made on both clear and cloudy days when NEE measurements were not feasible. During the 2009 field campaign, measurements were carried out on 16 days. The sampling order of the 16 collars was randomized each day.

\subsubsection{Environmental Va riables}

During chamber measurements, several environmental variables were measured within close proximity to each collar. Thermocouples permanently installed at 2, 5 and $10 \mathrm{~cm}$ soil depths and were measured using a digital thermometer (HH81 A, Omega, Laval, QC, Canada). Average soil volumetric water content $(0-20 \mathrm{~cm} \mathrm{VWC})\left(\mathrm{m}^{3} \mathrm{~m}^{-3}\right)$ was measured by inserting a probe (Hydrosense, Campbell Scientific Inc., Logan, UT, USA) vertically to a dep th of $20 \mathrm{~cm}$ from the soil surface. VWC was also measured continuously every $30 \mathrm{~min}$ at 5 and $10 \mathrm{~cm}$ depths within two lawn and two tussock 
communities with an additional measurement at $20 \mathrm{~cm}$ in each tussock community (logger: EM5b, probe: Echo EC-5, Decagon Devices Inc., New Hampshire, WA, USA).

The point frame method was used to assess vegetation characteristics at the peak of biomass (beginning of August). Forty-four pin drops were made at the intersection of grid lines within a $4 \times 4 \mathrm{~cm}$ grid, set over each collar. For each pin drop, the number of times green leaves touched the pin was recorded along with the plant functional type or species. If no vascular vegetation was touched but the pin contacted moss, this was noted separately. For each collar, $\%$ vascular cover, $\%$ moss cover and vascular leaf area index (LAI) was calculated. Total vascular LAI was calculated by dividing the total number of vascular vegetation "hits" by the total number of pin drops.

Thaw depth was recorded approximately every 10 days by inserting a steel rod 10 times into the peat at random locations along the fen boardwalk.

Water table depth was recorded, in reference to the lawn surface, using a float and potentiometer apparatus within a perforated polyvinyl chloride (PVC) pipe. Water table depth was also measured manually to establish a relationship between potentiometer readings and the water table depth.

\subsection{Ecosystem Exchange of $\mathrm{CO}_{2}$ and $\mathrm{CH}_{4}$}

\subsubsection{Eddy Covariance Measure ments of $\mathrm{CO}_{2}$ and $\mathrm{CH}_{4}$}

Fluxes of $\mathrm{CO}_{2}$ and $\mathrm{CH}_{4}$ were obtained from eddy covariance instrumentation mounted upon the fen tripod which was erected in 2006. The instrumentation included a 3D sonic anemometer (R3-50, Gill Institute, Lymington, $\mathrm{UK}$ ), and a $\mathrm{CO}_{2} / \mathrm{H}_{2} \mathrm{O}$ open-path infrared gas analyzer (IRGA) (LI-7500, LI-COR Inc., Lincoln, NE, USA) mounted at 2.5 m height from the peat surface. $\mathrm{CH}_{4}$ mol fraction was measured using a closed-path fast 
methane gas analyzer (FMGA) (907-0001-0002, Los Gatos Research, Mountainview, CA, USA) with air pulled through $3.5 \mathrm{~m}$ polyethylene coated tubing with an inner diameter of 4 mm (Dekabon Type 1300, Dekoron, Furon Brands, Aurora, Ohio, USA) by a pump (N920, KNF, Trenton, NJ, USA) approximately $10 \mathrm{~L} \mathrm{~min}^{-1}$. This flow rate resulted in an effective sampling rate of $1.5 \mathrm{~Hz}$ by the FMGA. Velocity in 3 dimensions, air temperature, $\mathrm{CO}_{2}$, and $\mathrm{H}_{2} \mathrm{O}$ mol density, and $\mathrm{CH}_{4}$ mol fraction were measured at a rate of $10 \mathrm{~Hz}$ and stored on a data logger (CR1000, Campbell Scientific, Logon, UT, USA).

The eddy covariance system was powered using batteries charged using a combination of solar power and a generator. Continuous operation of the FMGA only occurred at the beginning and end of the field campaign (11days). The charge controller failed early during the field campaign such that the FMGA was run directly off the generator for daytime periods.

\subsubsection{Environmental Variables}

Throughout the study period, the following environmental variables were recorded and stored at $30 \mathrm{~min}$ intervals: precipitation using a tipping bucket rain gauge (TE525m, Texas Electronics, Dallas, TX, USA), upwelling and downwelling photosynthetically active radiation (PAR) using quantum sensors (LI-190SA, LI-COR Inc., Lincoln, NB, USA), air temperature and humidity using a probe in a gill radiation shield (HMP45C, VaisalaOyj, Helsinki, Finland), atmospheric pressure using a barometer (PTB101B, VaisalaOyj, Helsinki, Finland), and wind speed using a propeller anemometer and vane (Wind Monitor, R. M. Young, Traverse City, IM, USA). These variables were measured at a nearby meteorological tower (Lafleur and Humphreys, 2008). On the tower at the fen, a four-component net radiometer (CNR1, Kipp\&Zonen B.V., Delft, the 
Netherlands) measured incoming and outgoing solar and long wave radiation. Copperconstantan thermocouples were installed at depths of $0.05,0.10,0.20$ and $0.60 \mathrm{~m}$ within the peat profile.

\subsection{Dissolved Organic Carbon}

At the beginning of the field campaign, sampling wells were installed at the inlet and outlet to the fen to measure hydraulic head. Each pair of wells was installed 15 meters up/downstream from each other at the outlet and 20 meters up/downstream at the inlet. At the inlet, 3 pairs of wells were installed 30 meters apart (in the approx. N-S direction) from each other for a total of 6 wells. At the outlet, 3 pairs of wells installed only 5 meters apart because the outlet was smaller in width than the inlet. Wells consisted of perforated PVC pipe cut to a length of 1.5 meters and installed to maximum thaw depth. Wells were measured on 4 days approximately 10 days apart. During measurements, hydraulic head was recorded for each pair of wells using a theodolite. At this time, a $60 \mathrm{ml}$ water sample was taken using a syringe. Samples were filtered and transferred to $100 \mathrm{ml}$ bottles and stored frozen. Samples were analyzed for DOC at McGill University on a Shimadzu 5050 Total Organic Carbon analyzer. On each sampling day, the wells were pushed down into the peat to the maximum extent of thaw depth.

\subsection{Data Analysis}

\subsubsection{Chamber Flux Calculation}

$\mathrm{CO}_{2}$ and $\mathrm{CH}_{4}$ flux $(F)$ for both the NEE and opaque static chamber systems was calculated using Equation 1, 


$$
F=\frac{V}{A} \frac{P}{R T} \frac{d x}{d t}
$$

where flux of $\mathrm{CO}_{2}$ and $\mathrm{CH}_{4}$ are in units of $\mu \mathrm{mol} \mathrm{m} \mathrm{m}^{-2} \mathrm{~s}^{-1}$ and $\mathrm{nmol} \mathrm{m} \mathrm{m}^{-2} \mathrm{~s}^{-1}$ respectively and is determined from a linear rate of change in gas species mixing ratio $(d x / d t)$, chamber area $(A)$ and volume $(V)$ in $\mathrm{m}^{2}$ and $\mathrm{m}^{3}$ respectively, barometric pressure $(P)$ in $\mathrm{Pa}$, the gas constant $(R) 8.314 \mathrm{~J} \mathrm{~K}^{-1} \mathrm{~mol}^{-1}$, and air temperature $(T)$ in Kelvin. Negative fluxes signify ecosystem uptake of $\mathrm{CO}_{2}$ or $\mathrm{CH}_{4}$, while positive fluxes signify the release of $\mathrm{CO}_{2}$ or $\mathrm{CH}_{4}$ from the ecosystem.

\subsubsection{NEE of $\mathrm{CO}_{2}$ and $\mathrm{CH}_{4}$ Flux Calculation}

The eddy covariance (EC) method measures turbulent exchange of energy and trace gases such as $\mathrm{CO}_{2}$ and $\mathrm{CH}_{4}$ (Baldocchi, 2003). Eddy flux is determined as the covariance between instantaneous deviation in vertical wind speed (w') from the mean value $(\bar{w})$ and instantaneous deviation in the scalar of interest $\left(\mathrm{s}^{\prime}\right)$ from the mean value $(\bar{s})$

$$
F=\overline{p_{a}} \overline{w^{\prime} s^{\prime}}
$$

where the flux is multiplied by the mean air density $\left(\mathrm{p}_{\mathrm{a}}\right)$. Several mathematical operations and assumptions, including Reynolds decomposition, are involved in deriving practical equations for computing flux from physically complete equations of the turbulent flow (Baldocchi, 2003). For the EC system described in this study, 30 min $\mathrm{CO}_{2}$ fluxes were computed from vertical velocity and $\mathrm{CO}_{2}$ mixing ratio as described by Lafleur and Humphreys (2008). The Webb-Pearman-Leuning procedure was applied to the 30 min $\mathrm{CH}_{4}$ fluxes to account for density fluctuations caused by humidity variation 
(Webb et al., 1980). Corrections for energy closure or for high frequency flux losses were not applied.

$\mathrm{NEE}$ was calculated as the sum of $30 \mathrm{~min} \mathrm{CO}_{2}$ flux and the rate in change of $\mathrm{CO}_{2}$ stored in the air column below the EC instrumentation (Lafleur and Humphreys, 2008). Quality control criteria described by Lafleur and Humphreys (2008) were used to remove fluxes that were physically or theoretically unsupported. In particular, this included removing fluxes at night when $\mathrm{u} *$ was below $0.1 \mathrm{~m} \mathrm{~s}^{-1}$ and during rainfall or when the diagnostic signal on the open-path IRGA indicated the path was obstructed. NEE is negative while GEP exceeds ER during daylight hours and is positive when photosynthesis ceases during the night (defined as PAR less than $20 \mu \mathrm{mol} \mathrm{m} \mathrm{m}^{-2}$ ) and during the day when ER exceeds GEP.

\subsubsection{Light-Te mperature Response}

The relationship between NEE and PAR and T is described by the following,

$$
N E E=\frac{G P_{\max } \alpha P A R}{G P_{\max }+\alpha P A R}+R_{10} Q_{10} \frac{\frac{T-\text { Tref }}{10}}{10}
$$

where the first term on the right-hand side of Equation 3 relates GEP to photosynthetically active radiation (PAR) through a rectangular hyperbolic relationship. The second term on the right describes the exponential relationship between ecosystem respiration (ER) and air temperature (T) within the chamber. $G P_{\max }$ is the maximum photosynthetic uptake of $\mathrm{CO}_{2}$ at saturating light; while, $\alpha$ is the effective quantum yield. $R_{10}$ is ER at a reference temperature $\left(T_{r e f}\right)$ of $10^{\circ} \mathrm{C}$, and $Q_{10}$ is the relative increase in ER for every $10{ }^{\circ} \mathrm{C}$ increase in temperature and is generally near 2 (Lloyd \& Taylor, 1994). 


\subsubsection{DOC Flux Calculation}

Through the use of Darcy's law, which relates the instantaneous discharge rate of a fluid through a medium to the viscosity of a fluid and the pressure drop over a given distance, it is possible to determine the flow rate and compute the inputs and outputs of DOC within a peatland catchment. A simplified version of Darcy's law is,

$$
Q=\kappa A \frac{d h}{d z}
$$

where $Q$ is the discharge rate $\left(\mathrm{m}^{3} \mathrm{~s}^{-1}\right), \kappa$ is permeability (saturated hydraulic conductivity) of peat $\left(\mathrm{m} \mathrm{s}^{-1}\right), A$ is the cross-sectional area $\left(\mathrm{m}^{2}\right)$, and $d h / d z$ is the difference in hydraulic head from one point to another $\left(\mathrm{m} \mathrm{m}^{-1}\right)$.

DOC flux for the growing season was determined using an average daily flux rate calculated for the entire study period and is explained as follows. As $\mathrm{k}$ was not measured, a value of $10^{-4} \mathrm{~m} \mathrm{~s}^{-1}$ was applied, which is between the generally accepted values of peat permeability $\left(10^{-2}\right.$ and $\left.10^{-5}\right)$ (Bear, 1972). Cross-sectional area was determined for the inlet and outlet, respectively, as the total width of the inlet $(240 \mathrm{~m})$ and outlet $(40 \mathrm{~m})$ multiplied by the average depth of water table above frost table for the 6 wells at each location for each sampling period. $d h / d z$ for the inlet and outlet was determined as the average difference between the hydraulic head for each of the 3 pairs of sampling wells. An average $Q$ for the inlet and outlet during the 3 sampling periods was determined and was multiplied by the average concentration $\left(\mathrm{mg} \mathrm{r}^{-1}\right)$ of DOC from the 6 wells at each location during the sampling period. The flux of DOC was determined as the difference between the discharge rate at the outlet and inlet. A negative value indicated DOC storage, while a positive value indicated DOC loss. As only three sampling periods occurred, in order to determine the growing season DOC flux, the three periods were 
averaged to determine an overall daily storage rate which was extrapolated for the entire growing season. This method likely represents an underestimation of the total DOC flux as measurements were not typically made during or immediately after large rain events.

\subsubsection{Flux Footprint}

Flux footprint (footprint distance) is defined as the area upwind where atmospheric flux is generated and measured by instrumentation downwind. Using an eddy covariance tower, it is a measure of the influence of an area to an observed vertical turbulent flux. Footprint distance is also known as fetch (Schuepp et al., 1990). The dimensions for the flux footprint representing the area from which $90 \%$ of the flux originates were calculated using FSAMwin. exe (Schmid, 1994). Input parameters included the height of the EC instrumentation $(2.5 \mathrm{~m})$, roughness length $(0.02 \mathrm{~m})$, stability (MoninObukhov length, L) and the ratio of the standard deviation of lateral velocity to friction velocity $\left(\sigma_{\mathrm{v}} / \mathrm{u}_{*}\right)$.

\subsubsection{Gap-filling and $C$ budget Calculations}

In order to determine the growing season $\mathrm{CH}_{4}$ emission, it was necessary to determine a functional relationship between $\mathrm{CH}_{4}$ flux and its primary environmental drivers which could be used for extrapolation and gap-filling. A relationship between temperature and frictional velocity has been well documented in previous studies (Friborg et al., 2000; Wille et al., 2008) and are included in the model following their approaches as, 


$$
C H_{4} F l u x=\cos b^{\frac{T-T_{\text {ref }}}{10}} \times c^{u *-u^{*} \text { ref }}
$$

where $\mathrm{CH}_{4}$ flux is the measured flux, $a, b$, and $c$ are the parameters fit using non-linear least squares regression with $5 \mathrm{~cm}$ soil temperature $(T)$ and friction velocity $(u *)$ as the independent variables and $T_{r e f}$ and $u *_{r e f}$ are the mean values during the measurement period. A combination of linear interpolation and empirical modelling was used to gapfill NEE as described by Lafleur and Humphreys (2008). For short periods with gaps of one or two half hours, linear interpolation was used; however, for longer periods, variations in 30-min NEE were modelled using the functional relationship described in Equation 3. Following the procedure of Lafleur and Humphreys (2008), modelled values were adjusted for seasonal variations in ER and GEP caused by phenology, moisture limitations, nutrient supply, etc, were applied by fitting predicted ER and GEP to observed fluxes using a moving window. For a more detailed explanation see Lafleur and Humphreys (2008).

To determine the growing season $\mathrm{C}$ budget, modelled growing season daily NEE was summed and losses of $\mathrm{C}$ through $\mathrm{CH}_{4}$ emission (modelled with Equation 5), and DOC export (determined using Equation 4) were subtracted. To determine the radiative forcing potential of the fen, methodology outlined by the IPCC (2007) was used to give a GWP for the growing season. IPCC (2007) states that $\mathrm{CH}_{4}$ has, on a per gram of $\mathrm{C}$ basis, 72 and 21 times the GWP of $\mathrm{CO}_{2}$ over the 20 year and 100 year timescale, respectively.

\subsection{Statistical Analysis}

All statistical analysis of data was performed using JMP (J.M.P.8 Statistical Analysis Software, 2008). One-way analysis of variance (ANOVA) was used to 
determine differences in vegetation and microclimate characteristics among lawn and tussock variables. Post-hoc multiple comparisons were computed using the Tukey's Honest Significant Difference test (HSD). The influence of vegetation community (lawns and tussocks) and time on $\mathrm{CO}_{2}$ and $\mathrm{CH}_{4}$ fluxes was assessed using repeatedmeasure analysis of variance (RM ANOVA). Spearman's correlation was used to test for significant relationships between environmental variables, $\mathrm{CO}_{2}$, and $\mathrm{CH}_{4}$ flux, and least squares linear regression was used to characterize the dependence of fluxes on biotic and abiotic variables. Tests were significant when $\mathrm{p}<0.05$. 


\subsection{RESULTS}

\subsection{Site Characteristics}

Vegetation and soil characteristics of lawns and tussocks are listed in Table 1.

The average height difference between lawns and tussocks was approximately $15 \mathrm{~cm}$.

Both tussocks and lawns had 100\% Sphagnum moss cover and there were no significant differences in total vascular LAI or vascular cover between the two communities. There was some difference in the species composition between the two communities with significantly greater LAI for Andromeda polifolia and significantly less LAI for the sedges on the tussocks; although, the dominant vascular species for both lawns and tussocks were sedge species.

Table 1. Soil and vegetation characteristics of the lawn and tussock environments. Values in brackets are the standard error of the mean $( \pm 1 \mathrm{SE})$ for the 8 tussock and 8 lawn collars. Values with different superscripts denote significant differences between communities $(\mathrm{p}<0.05)$. * Source (Hayne, 2009).

\begin{tabular}{|c|c|c|}
\hline & Lawns & Tussocks \\
\hline Soil Texture & \multicolumn{2}{|c|}{ Peat over Silt Loam } \\
\hline Depth of Organic Layer $(\mathrm{cm})^{*}$ & $40-50$ & $50-60$ \\
\hline $\begin{array}{l}\text { Average Organic Matter Content } 0-25 \\
\mathrm{~cm} \text { depth }\left(\mathrm{kg} \mathrm{m}^{-2}\right)^{*}\end{array}$ & \multicolumn{2}{|c|}{$21.56(1.26)$} \\
\hline $\begin{array}{l}\text { Average Leaf Area Index } \\
\text { (live leaf area per unit ground }\left(\mathrm{m}^{2} \mathrm{~m}^{-2}\right)\end{array}$ & $0.77(0.03)^{\mathrm{a}}$ & $0.83(0.07)^{\mathrm{a}}$ \\
\hline $\begin{array}{l}\text { Average Leaf Area Index }- \text { Andromeda } \\
\text { polifolia (live leaf area per unit ground } \\
\left(\mathrm{m}^{2} \mathrm{~m}^{-2}\right)\end{array}$ & $0.06(0.03)^{\mathrm{a}}$ & $0.31(0.03)^{b}$ \\
\hline $\begin{array}{l}\text { Average Leaf Area Index - sedges } \\
\text { (live lea farea per unit ground }\left(\mathrm{m}^{2} \mathrm{~m}^{-2}\right)\end{array}$ & $0.69(0.03)^{\mathrm{a}}$ & $0.51(0.04)^{b}$ \\
\hline Vascular Cover $(\%)$ & $48.3(1.09)^{\mathrm{a}}$ & $55.27(3.37)^{\mathrm{a}}$ \\
\hline Moss Cover $(\%)$ & $100(0)^{\mathrm{a}}$ & $100(0)^{\mathrm{a}}$ \\
\hline Dominant Vascular Species & $\begin{array}{c}\text { Carex spp. } \\
\text { Eriophorum spp. }\end{array}$ & $\begin{array}{c}\text { Carex spp. } \\
\text { Eriophorum spp. }\end{array}$ \\
\hline
\end{tabular}


Tussock tops remained well above the water table for the duration of the sampling period. The water table gradually decreased from a high of $4 \mathrm{~cm}$ to approximately $14 \mathrm{~cm}$ below the lawn surface with some fluctuations associated with small precipitation events (Figure 5). Consequently, there were significant differences between mean VWC for the lawns and tussocks at depths of 5 and $10 \mathrm{~cm}$ and integrated over $0-20 \mathrm{~cm}$ (Table $2 \&$ Figure 5). The $0-20 \mathrm{~cm} \mathrm{VWC} \mathrm{gradually} \mathrm{decreased} \mathrm{throughout} \mathrm{the} \mathrm{study} \mathrm{period} \mathrm{for}$ tussocks while, there was no clear trend in the lawns as the water table remained within this $20 \mathrm{~cm}$ surface layer (Figure 5). Due to the high heat capacity of water, soil temperature at depths of 2,5 , and $10 \mathrm{~cm}$ remained cooler in the lawns than in the tussocks throughout the study (Figure $6 \&$ Table 2). Both lawns and tussocks showed considerable variations in $2 \mathrm{~cm}$ soil temperature through the sampling period as air temperature varied (Figure 6). Mean daily air temperature and soil temperature at $2 \mathrm{~cm}$ reached peak values in mid to late July (DOY 199-205) (Figure 6). Thaw depth gradually increased during the field season (Figure 6) with a maximum thaw depth of $47.4 \mathrm{~cm}$ below the lawn surface and $62.4 \mathrm{~cm}$ below the tussock surface (Table 2).

Table 2. Environmental characteristics of the lawn and tussock communities. Values in brackets are \pm 1 SE. Values with different superscripts denote significant differences between communities $(\mathrm{p}<0.05)$.

\begin{tabular}{l|ll}
\hline & Lawns & Tussocks \\
\hline Mean soil temperature at $2 \mathrm{~cm}$ & $14.7(0.3)^{\mathrm{a}}$ & $15.7(0.3)^{\mathrm{b}}$ \\
Mean soil temperature at $5 \mathrm{~cm}$ & $11.3(0.2)^{\mathrm{a}}$ & $12.8(0.3)^{\mathrm{b}}$ \\
Mean soil temperature at $10 \mathrm{~cm}$ & $7.9(0.1)^{\mathrm{a}}$ & $9.3(0.2)^{\mathrm{b}}$ \\
Mean VWC $\left(\mathrm{m}^{3} \mathrm{~m}^{-3}\right)(0-20 \mathrm{~cm})$ & $86.2(1.2)^{\mathrm{a}}$ & $41.4(2.0)^{\mathrm{b}}$ \\
Mean VWC $\left(\mathrm{m}^{3} \mathrm{~m}^{-3}\right) 5 \mathrm{~cm}$ & $76.9(0.4)^{\mathrm{a}}$ & $34.3(0.1)^{\mathrm{b}}$ \\
Mean VWC $\left(\mathrm{m} \mathrm{m}^{3}\right) 10 \mathrm{~cm}$ & $87.5(0.01)^{\mathrm{a}}$ & $32.8(0.1)^{\mathrm{b}}$ \\
Maximum thaw depth $(\mathrm{cm})$ & $47.4(0.8)$ & $62.4(0.8)$ \\
\hline
\end{tabular}



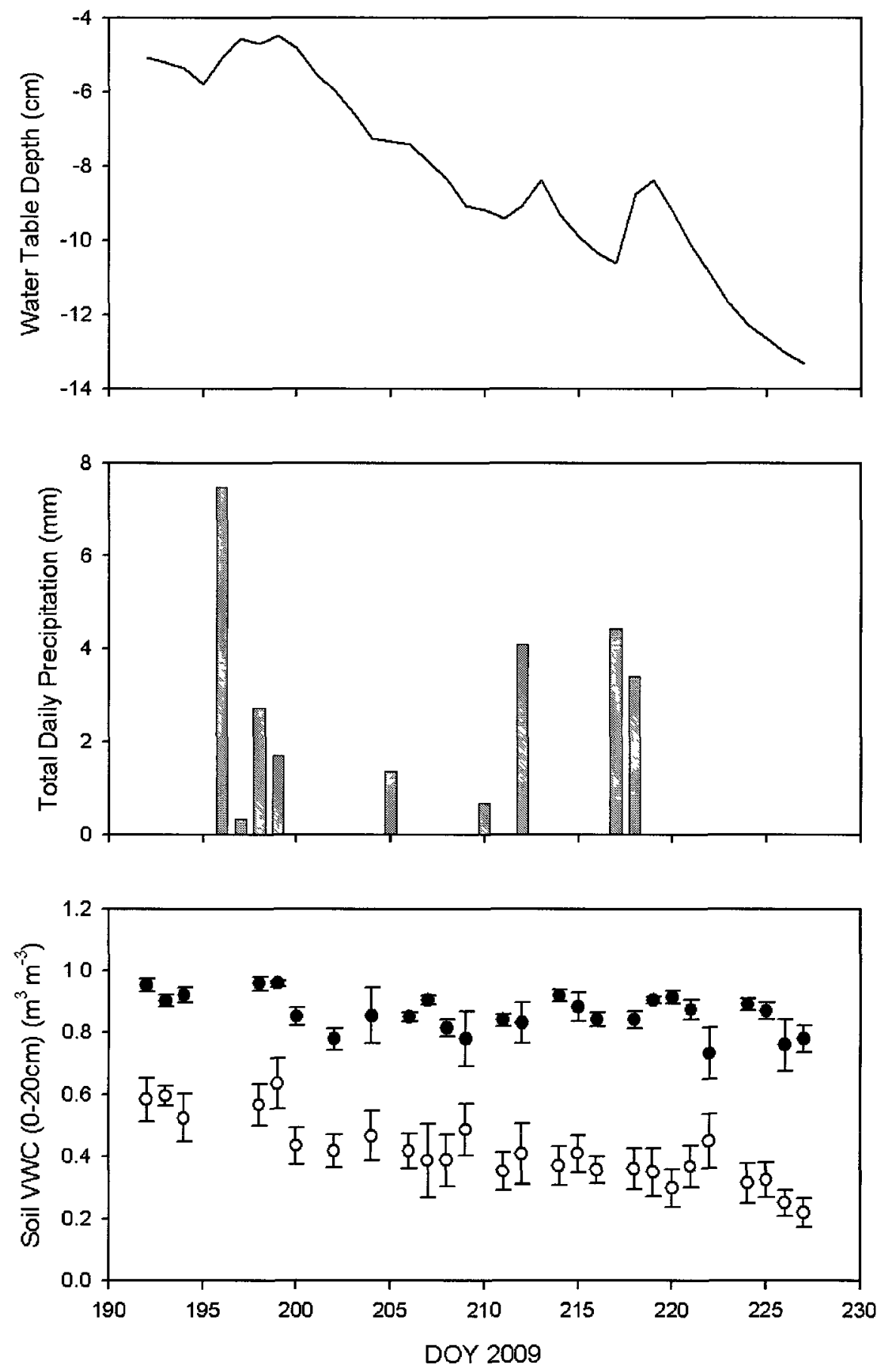

Figure 5. Daily average water table depth relative to the lawn surface, total daily precipitation, and average soil volumetric water content (VWC) for the $0-20 \mathrm{~cm}$ layer of lawns (closed circles) and tussocks (open circles) at Daring Lake, NT from July $11^{\text {th }}$ to August $15^{\text {th }}, 2009$. Error bars represent \pm 1 standard error $( \pm 1 \mathrm{SE})$. 

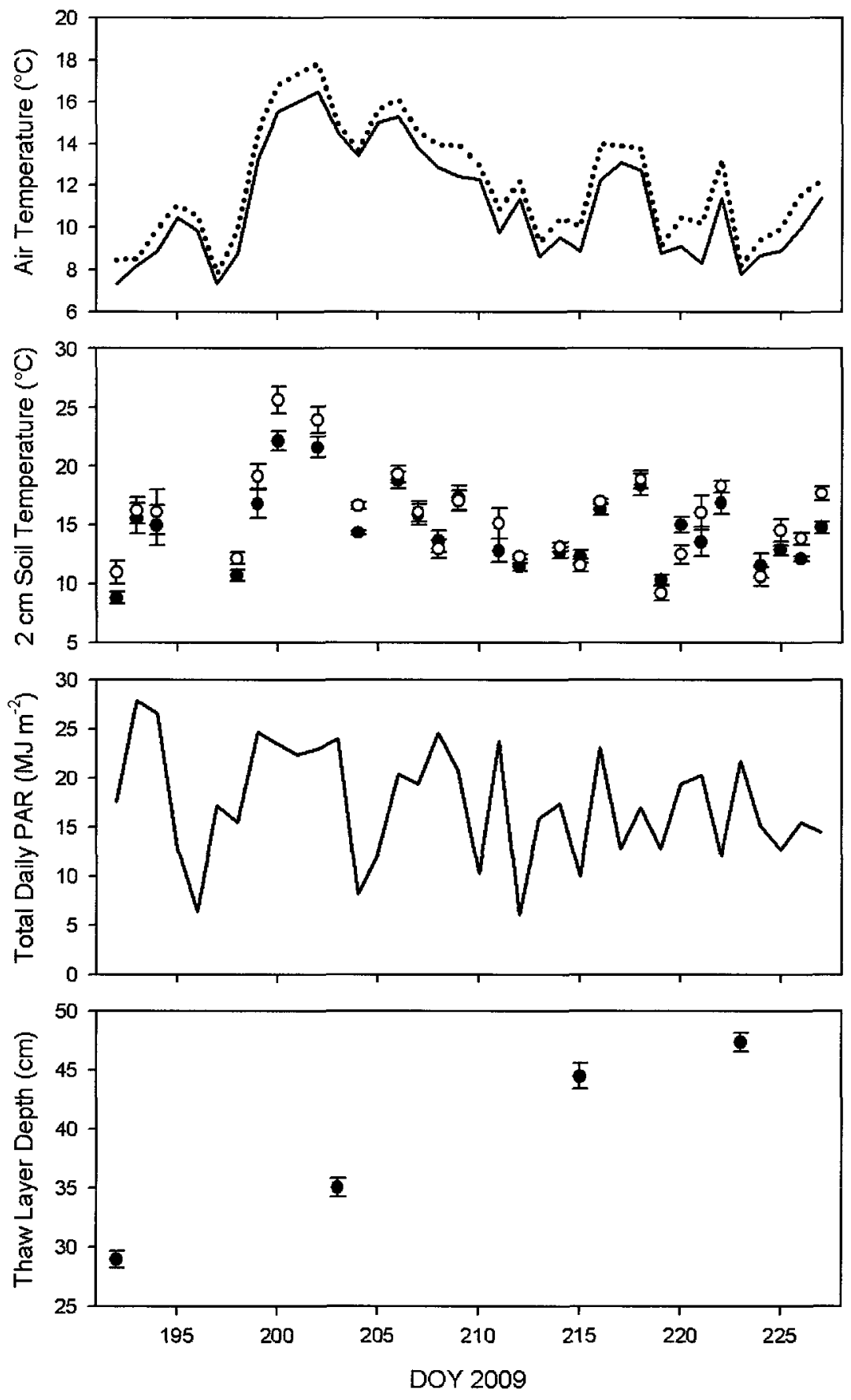

Figure 6. Average daily air temperature (so lid line), average daily daytime air temperature (PAR $>10 \mathrm{~W} \mathrm{~m}^{-2}$ ) (dotted line), average soil temperature at $2 \mathrm{~cm}$ depth for lawns (closed circles) and tussocks (open circles), daily photosynthetically active radiation (PAR), and thaw layer depth at Daring Lake, NT from July $11^{\text {th }}$ to August $15^{\text {th }}$, 2009. Error bars represent \pm 1 SE. The number of samples for each $2 \mathrm{~cm}$ soil temperature symbol is 8 . The number of samples for each thaw layer depth symbol is 15 . 


\subsection{Carbon Exchange}

\subsubsection{Spatial Variations in $\mathrm{CO}_{2}$ Fluxes}

$\mathrm{NEE}_{\max }, \mathrm{GEP}_{\max }$, and $\mathrm{ER}_{\mathrm{F}}$ were not significantly different among lawns and tussocks (RM ANOVA (Treatment): $\mathrm{F}_{1,14}=0.01 \mathrm{p}=0.91 ; \mathrm{F}_{1,14}=0.43 \mathrm{p}=0.52 ; \mathrm{F}_{1,14}=$ $0.67 \mathrm{p}=0.43$, respectively) (Table 3 ). However, $\mathrm{ER}_{\mathrm{F}}$ was significantly greater than $\mathrm{ER}_{\mathrm{S}}$ (ANOVA: $\left.\mathrm{F}_{1}=93.96, \mathrm{p}=0.0001\right)($ Table 3$)$ possibly because the NEE chamber system was preferentially used on sunnier, warmer days. As a result, the average $2 \mathrm{~cm}$ soil temperature measured during the $\mathrm{ER}_{\mathrm{F}}$ measurements was $16.8( \pm 0.3){ }^{\circ} \mathrm{C}$ vs. $13.5( \pm 0.2)$ ${ }^{\circ} \mathrm{C}$ for the $\mathrm{ER}_{\mathrm{S}}$ measurements. Nonetheless, like $\mathrm{ER}_{\mathrm{F}}, \mathrm{ER}_{\mathrm{S}}$ was not significantly different between lawns and tussocks (RM ANOVA (Treatment): $\left.F_{1,14}=0.06, p=0.81\right)$.

Variability in NEE was well described using Equation 3 for both tussocks and lawns (Table 4 \& Figure 7). Similarly, $\mathrm{GP}_{\max }$ and $\mathrm{R}_{10}$ were not significantly different among lawns and tussocks (Table 4). The value of $R_{10}$ was lower than the average $E_{F}$ (Table 3 \& Table 4) as expected because field measurements were made when near surface air and soil temperatures were typically well above $10^{\circ} \mathrm{C}$ (Figure 6). $\mathrm{Q}_{10}$ was approximately 1.3 and considerably lower than the typical value of 2 (Lloyd \& Taylor, 1994) possibly because chamber air temperature may not represent the temperature influencing both above and below ground respiration processes. 
Table 3. Average NEE and component fluxes for the two vegetation communities. $\mathrm{NEE}_{\text {max }}$ is the net ecosystem exchange of $\mathrm{CO}_{2}$ for PAR greater than $1000 \mu \mathrm{mol} \mathrm{m} \mathrm{m}^{-2} \mathrm{~s}^{-1}$. GEP $_{\max }$ is the average gross ecosystem production for PAR greater than $1000 \mu \mathrm{mol} \mathrm{m} \mathrm{m}^{-2}$ ${ }^{1}$. ER is the average ecosystem respiration in the dark measured using the flow-through chambers $\left(E R_{F}\right)$ and the static chambers $\left(E R_{S}\right)$. Values in brackets represent $\pm 1 \mathrm{SE}$. Values with different superscripts denote significant differences between communities ( $p$ $<0.05)$.

\begin{tabular}{l|cc}
\hline & Lawns & Tussocks \\
\hline $\mathrm{NEE}_{\max }\left(\mu \mathrm{mol} \mathrm{m}^{-2} \mathrm{~s}^{-1}\right)$ & $-1.93(0.09)^{\mathrm{a}}$ & $-1.87(0.11)^{\mathrm{a}}$ \\
$\mathrm{GEP}_{\max }\left(\mu \mathrm{mol} \mathrm{m}^{-2} \mathrm{~s}^{-1}\right)$ & $-3.92(0.11)^{\mathrm{a}}$ & $-4.02(0.13)^{\mathrm{a}}$ \\
$\mathrm{ER}_{\mathrm{F}}\left(\mu \mathrm{mol} \mathrm{m} \mathrm{s}^{-1}\right)$ & $1.99(0.07)^{\mathrm{a}}$ & $2.15(0.10)^{\mathrm{a}}$ \\
$\mathrm{ER}_{\mathrm{S}}\left(\mu \mathrm{mol} \mathrm{m} \mathrm{s}^{-1}\right)$ & $1.38(0.04)^{\mathrm{a}}$ & $1.37(0.05)^{\mathrm{a}}$ \\
\hline
\end{tabular}

Table 4. Parameters for Equation 3 describing the response of NEE to PAR and chamber air temperature for the two communities. $\mathrm{GP}_{\max }$ is maximum gross photosynthesis, $\alpha$ is the initial slope of the curve, $R_{10}$ is ecosystem respiration at a reference temperature of 10 ${ }^{\circ} \mathrm{C}, \mathrm{n}$ is the number of observations, $\mathrm{Q}_{10}$ is rate of increase in ER for a $10^{\circ} \mathrm{C}$ increase in temperature, and RMSE is the root mean square error. Values in brackets represent \pm 1 SE. Values with different superscripts denote significant differences between communities $(p<0.05)$.

\begin{tabular}{l|ll}
\hline & Lawns & Tussocks \\
\hline $\mathrm{GP}_{\max }\left(\mu \mathrm{mol} \mathrm{m} \mathrm{m}^{-2} \mathrm{~s}^{-1}\right)$ & $-6.17(0.46)^{\mathrm{a}}$ & $-6.27(0.56)^{\mathrm{a}}$ \\
$\alpha$ & $-0.007(0.0007)^{\mathrm{a}}$ & $-0.008(0.001)^{\mathrm{a}}$ \\
$\mathrm{R}_{10}\left(\mu \mathrm{mol} \mathrm{m} \mathrm{s}^{-2} \mathrm{~s}^{-1}\right)$ & $1.37(0.09)^{\mathrm{a}}$ & $1.54(0.11)^{\mathrm{a}}$ \\
$\mathrm{n}$ & 396 & 400 \\
$\mathrm{Q}_{10}$ & $1.36(0.07)^{\mathrm{a}}$ & $1.33(0.07)^{\mathrm{a}}$ \\
$\mathrm{RMSE}$ & 0.757 & 1.014 \\
\hline
\end{tabular}



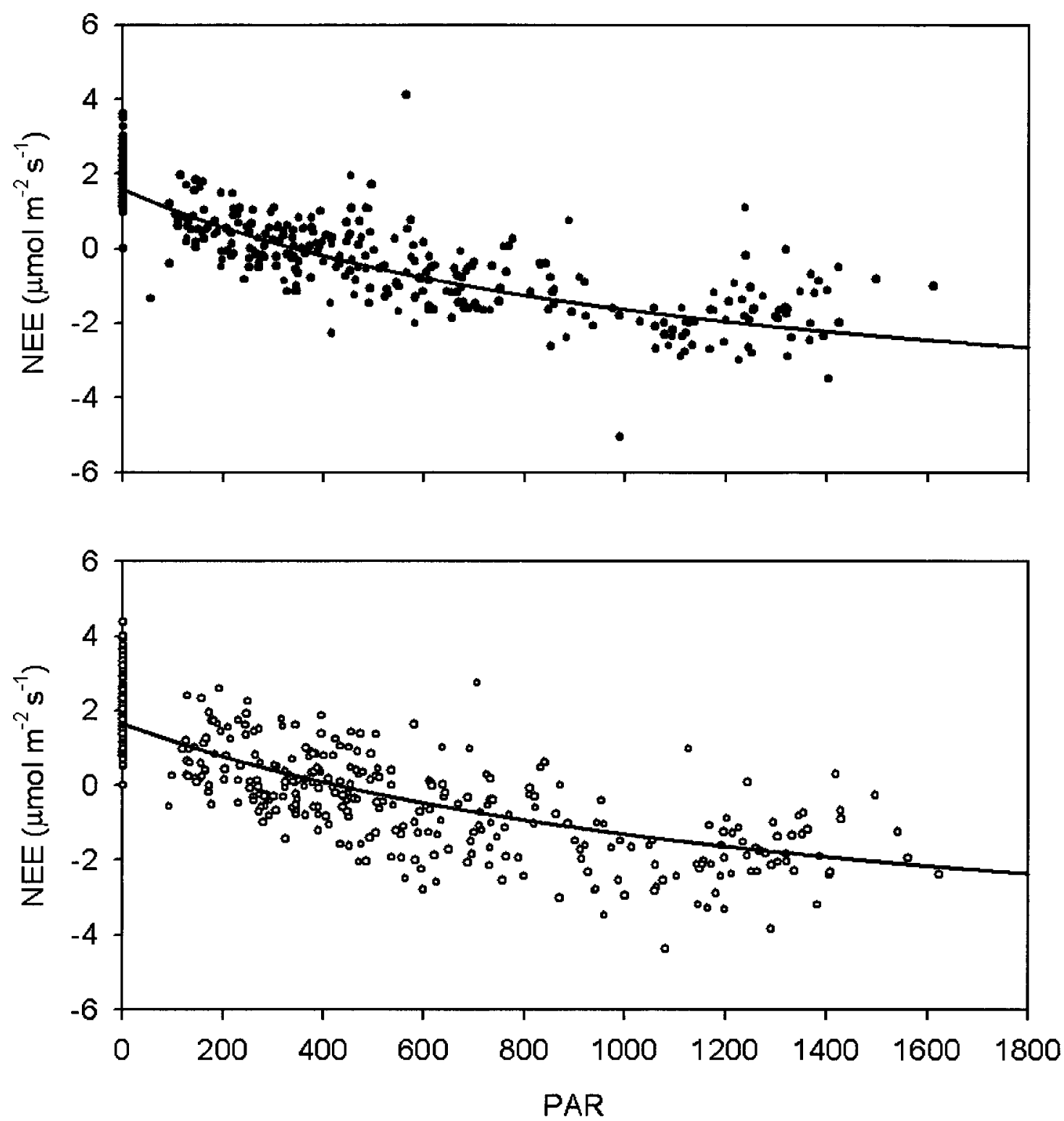

Figure 7. The top and bottom panels show the relationship between net ecosystem exchange of $\mathrm{CO}_{2}$ (NEE) and photosynthetically active radiation (PAR) for lawns and tussocks, respectively. The light response curves are shown as solid lines. Curves (solid lines) are determined using Equation 3 with parameters listed in Table 4. 
Although there was no significant difference in $\mathrm{CO}_{2}$ exchange between the two community types, there was considerable variation in the average $\mathrm{NEE}_{\max }$ and component fluxes among the collars. Overall, vegetation characteristics appeared to play an important role in determining variations in $\mathrm{NEE}_{\max }$ and $\mathrm{GEP}_{\max }$ among collars. LAI significantly correlated with both $\mathrm{NEE}_{\max }(\mathrm{r}=-0.48, \mathrm{p}=0.04)$ and $\mathrm{GEP}_{\max }(\mathrm{r}=-0.61, \mathrm{p}=$ $0.01)$ but not $E R_{F}(r=0.26, p=0.32)$. Stronger relationships were found for $\operatorname{NEE}_{\max }(r=$ $-0.81, \mathrm{p}=0.0001)$ and $\mathrm{GEP}_{\max }(\mathrm{r}=-0.66, \mathrm{p}=0.006)$ with $\%$ vascular cover $($ Figure 8$)$. Consequently, because LAI and vascular $\%$ cover did not significantly differ between lawns and hummocks, it was not surprising that $\mathrm{CO}_{2}$ sequestration $\left(\mathrm{GP}_{\max }\right.$ and GEP $\mathrm{max}_{\text {max }}$ ) and thus $\mathrm{NEE}_{\max }$ also did not differ. $\mathrm{ER}_{\mathrm{F}}$ did not significantly correlate directly with any vegetation characteristics but was found to significantly correlate to $\operatorname{GEP}_{\max }(r=-0.61, p$ $=0.01)$. Although these two fluxes are not independent, this may indicate that ER is largely related to variations in productivity directly through autotrophic respiration processes and through decomposition of fresh substrates. None of the $\mathrm{CO}_{2}$ fluxes measured with the flow-through chamber were significantly correlated to soil temperature or moisture variables. This suggested that cooler and wetter conditions did not reduce the growth (GEP) of these species well adapted to saturated conditions.

In contrast to $\mathrm{ER}_{\mathrm{F}}, \mathrm{ER}_{\mathrm{S}}$ was found to significantly and positively correlate with soil temperature at $2 \mathrm{~cm}(\mathrm{r}=0.59, \mathrm{p}=0.02)$ possibly because sampling occurred on a greater number of days (16 vs. 13 ). ER $_{S}$ did not vary significantly with any biotic variable and similar to $\mathrm{ER}_{F}$, it had a significant negative correlation with $\operatorname{GEP}_{\max }(\mathrm{r}=-$ $0.59, \mathrm{p}=0.02)$ 

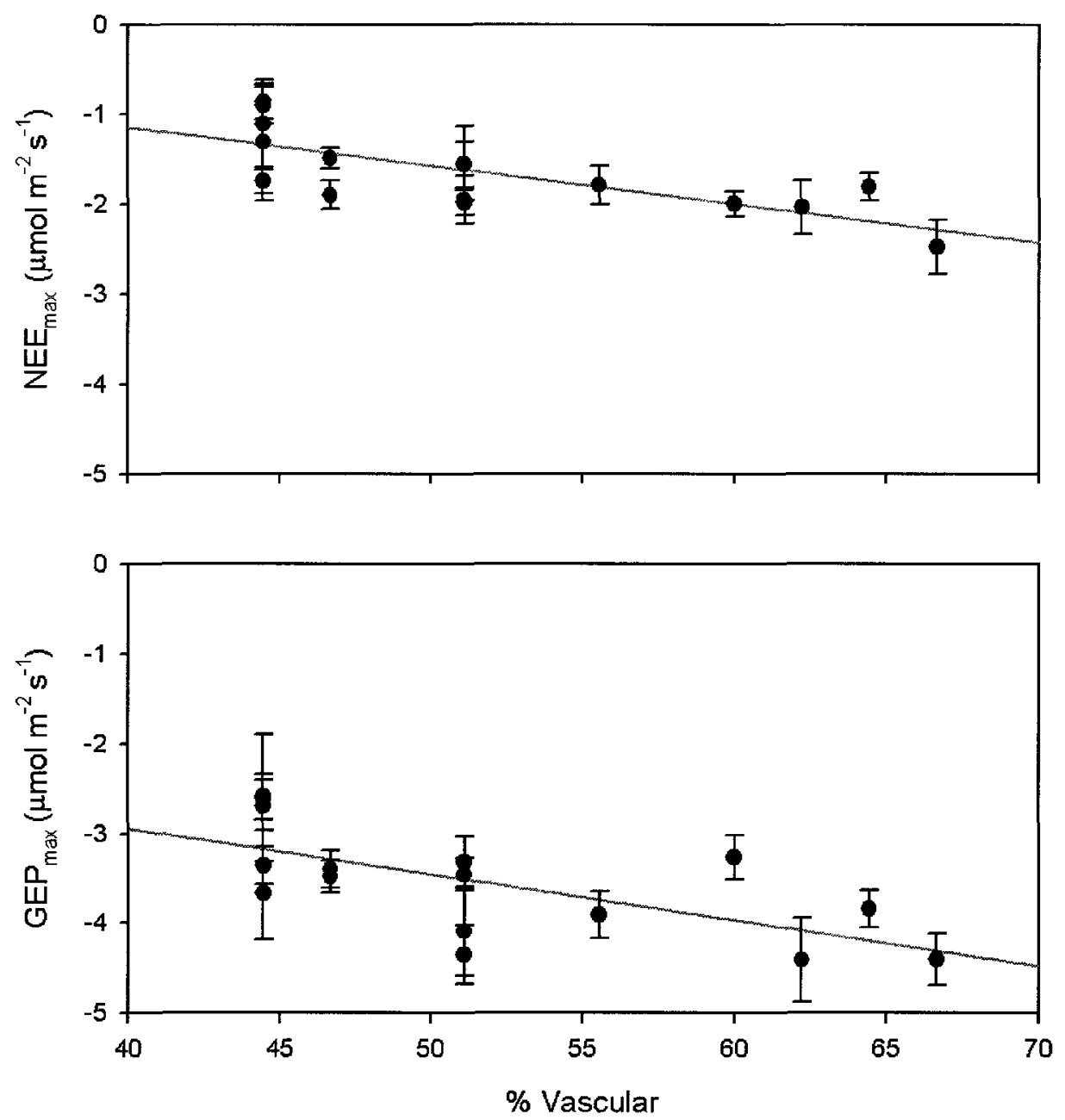

Figure 8. The relationship between net ecosystem exchange of $\mathrm{CO}_{2}\left(\mathrm{NEE}_{\max }\right)$ (top panel) and gross ecosystem exchange of $\mathrm{CO}_{2}\left(\mathrm{GEP}_{\max }\right)$ (bottom panel) to \% vascular. Error bars represent $\pm 1 \mathrm{SE}$. The number of samples for each symbol is 13 . Lines are given for significant linear regressions $\left(\mathrm{NEE}_{\max }=-0.04(\%\right.$ Vascular $)+0.55, \mathrm{r}^{2}=0.56 ; \mathrm{GEP}_{\max }=-$ 0.05 (\% Vascular) - 0.92, $\left.\mathrm{r}^{2}=0.43\right)$. 


\subsubsection{Spatial Variations in $\mathrm{CH}_{4}$ Fluxes}

$\mathrm{CH}_{4}$ flux was found to be significantly different among lawns and tussocks (RM ANOVA (Treatment): $\mathrm{F}_{1,14}=8.03, \mathrm{p}=0.01$ ). The range in observed $\mathrm{CH}_{4}$ fluxes was nearly twice as large in lawns than in tussocks, and, when assessed, the average $\mathrm{CH}_{4}$ flux was significantly greater in lawns $\left(58.21 \pm 2.10 \mathrm{nmol} \mathrm{m}^{2} \mathrm{~s}^{-1}\right)$ than in tussocks (34.82 $\pm 1.52 \mathrm{nmol} \mathrm{m}^{2} \mathrm{~s}^{-1}$ ) (Table 5). Wetter collar sites were associated with higher $\mathrm{CH}_{4}$ fluxes (Figure 9) $(r=0.66, p=0.005)$. When examining the spatial variations within the two communities, lawn $\mathrm{CH}_{4}$ flux was not significantly correlated to any abiotic variable; however, tussock $\mathrm{CH}_{4}$ flux was significantly positively correlated to soil temperature at 2 cm depth $(r=0.71, p=0.04)($ Figure 10$) . \mathrm{CH}_{4}$ flux did not significantly correlate to $\mathrm{ERS}_{\mathrm{S}}$ $(r=0.45, p=0.08), E_{F}(r=0.003, p=0.991), N E_{m a x}(r=-0.21, p=0.44)$ or $\operatorname{GEP}_{\max }(r$ $=-0.27, p=0.31)$ when the full set of collars was investigated. However, there was a significant positive correlation between $\mathrm{CH}_{4}$ flux and $\mathrm{ER}_{\mathrm{S}}$ within tussocks $(\mathrm{r}=0.76, \mathrm{p}=$ 0.03 ) but not for lawns $(\mathrm{r}=0.47, \mathrm{p}=0.23)$ (Figure 11). $\mathrm{CH}_{4}$ flux did not relate to any biotic variable when examining lawn and tussock communities; however, when the full set of collars was assessed, $\mathrm{CH}_{4}$ had a significant positive correlation to sedge $\mathrm{LAI}(\mathrm{r}=$ $0.61, \mathrm{p}=0.01)$ and a significant negative correlation to bog rosemary LAI $(\mathrm{r}=-0.51, \mathrm{p}=$ 0.04). 
Table 5. The range and mean $\mathrm{CH}_{4}$ flux for the lawn and tussock communities. Values in brackets represent $\pm 1 \mathrm{SE}$. Values with different superscripts denote significant differences between communities $(p<0.05)$. The number of samples for lawns and tussocks is 132 .

\begin{tabular}{|c|c|c|c|}
\hline & & Lawns & Tussocks \\
\hline \multirow[t]{3}{*}{$\mathrm{CH}_{4}$ flux $\left(\mathrm{nmol} \mathrm{m}^{-2} \mathrm{~s}^{-1}\right)$} & Minimum & 7.85 & 1.84 \\
\hline & Maximum & 164.76 & 80.24 \\
\hline & Mean (SE) & $58.21(2.10)^{\mathrm{a}}$ & $34.82(1.52)^{b}$ \\
\hline
\end{tabular}




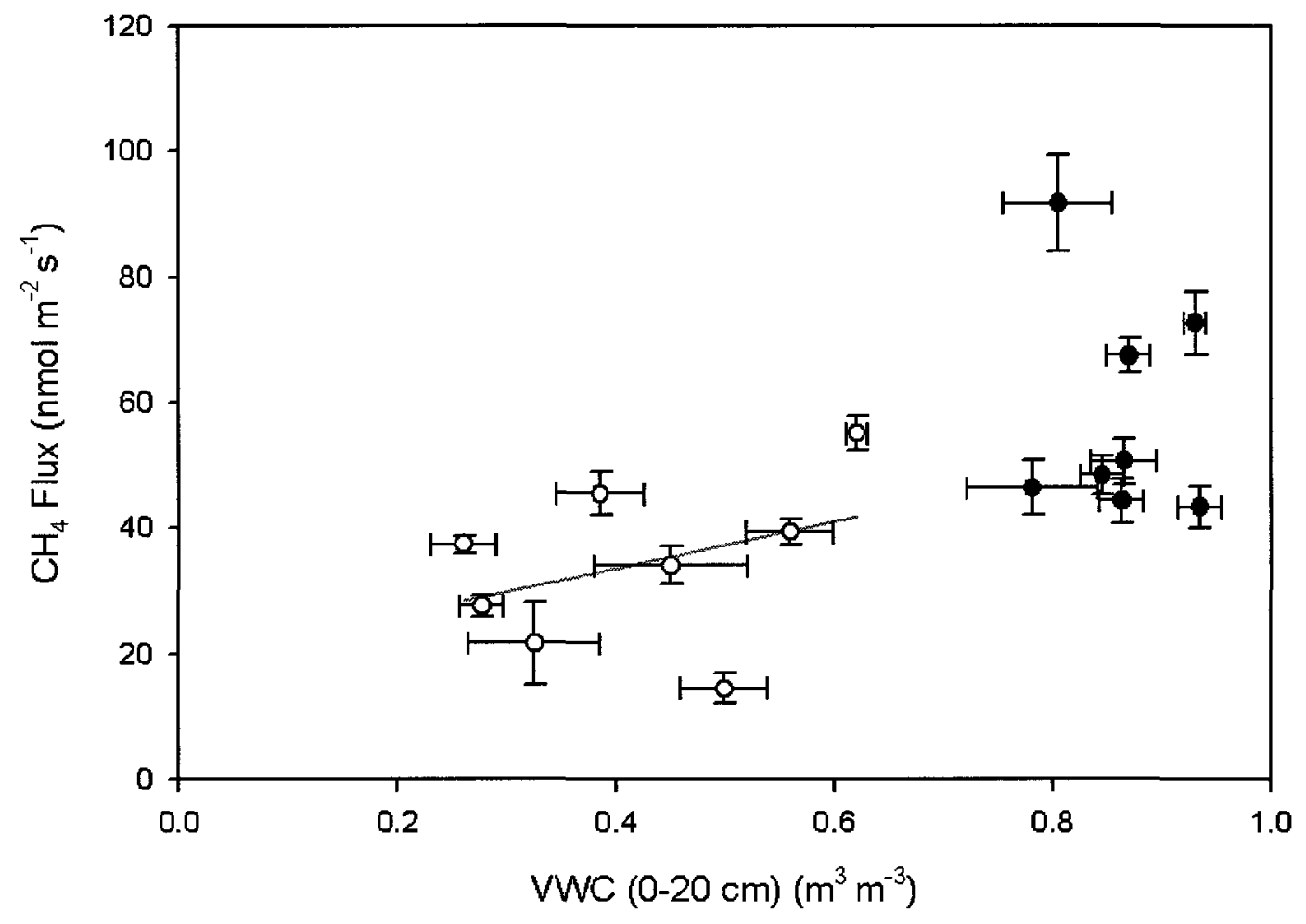

Figure 9. Relationship between $\mathrm{CH}_{4}$ Flux and volumetric water content (VWC) for lawns (dark circles) and tussocks (open circles). Error bars represent \pm 1 SE. The number of samples for each symbol is 16. Lines are given for significant linear regressions $\left(\mathrm{CH}_{4}\right.$ Flux $=37.35($ VWC $\left.)+18.62, \mathrm{r}^{2}=0.24\right)$. 


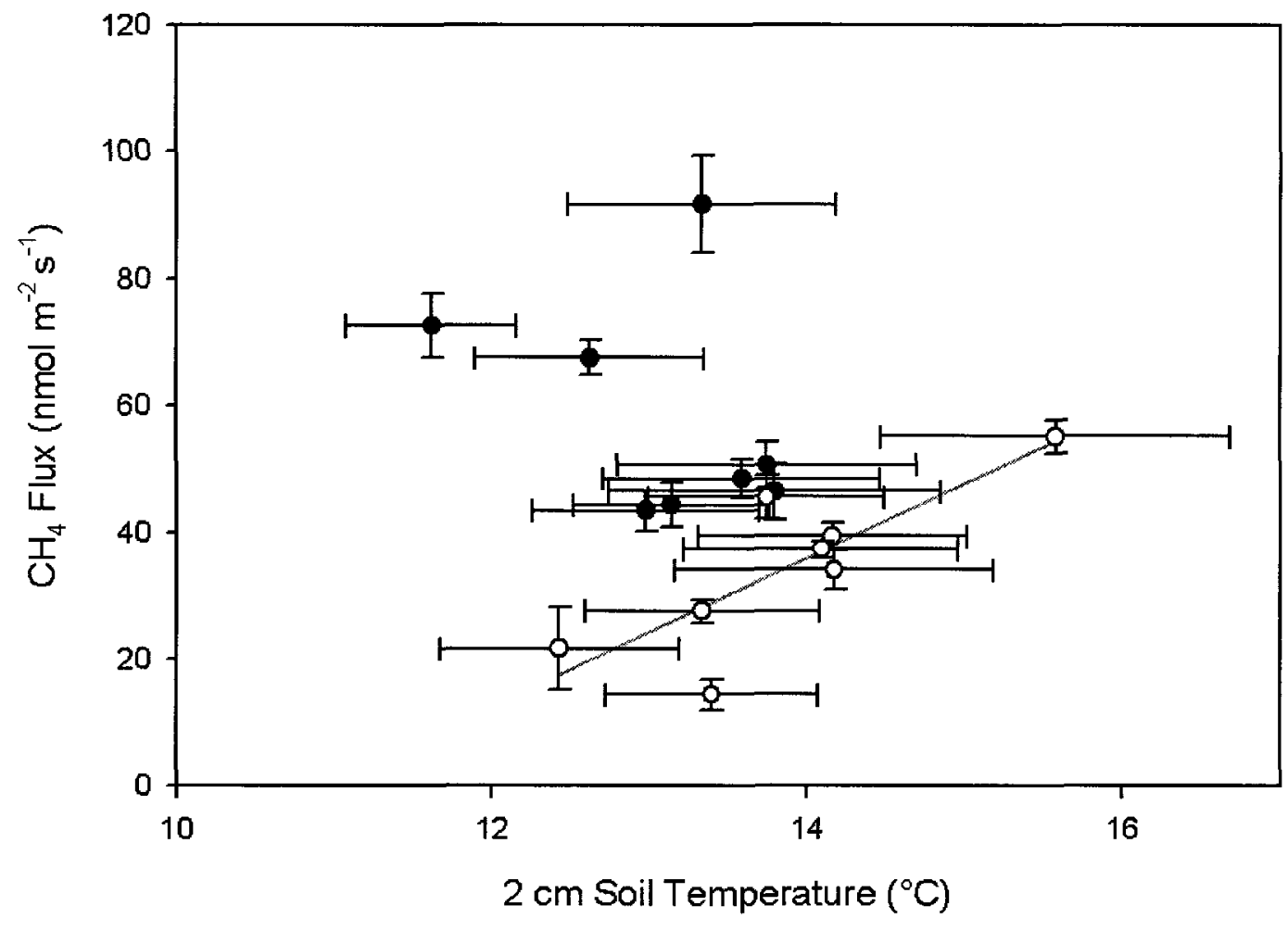

Figure 10. Relationship between $2 \mathrm{~cm}$ soil temperature and $\mathrm{CH}_{4}$ flux for lawns (dark circles) and tussocks (open circles). Error bars represent \pm 1 SE. The number of samples for each symbol is 16 . Lines are given for significant linear regressions $\left(\mathrm{CH}_{4} \mathrm{Flux}=\right.$ 11.72 (Temperature) - $128.1, \mathrm{r}^{2}=0.66$ ). 


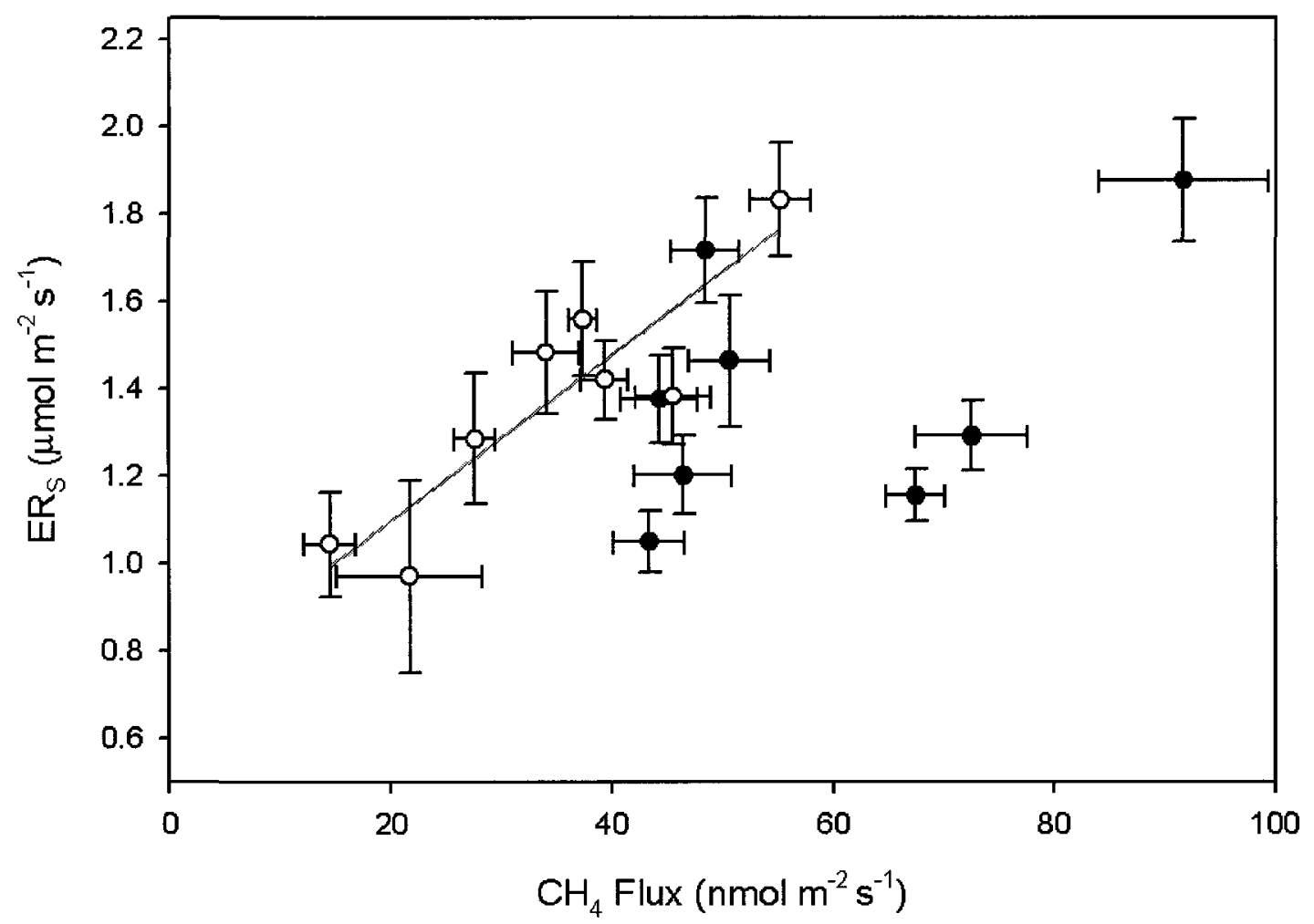

Figure 11. The relationship between ecosystem respiration (static chamber) (ERs) and $\mathrm{CH}_{4}$ flux for lawns (dark circles) and tussocks (open circles). Error bars represent $\pm 1 \mathrm{SE}$. The number of samples for each symbol is 16 . Lines are given for significant linear regressions $\left(\mathrm{ER}_{\mathrm{S}}=0.02\left(\mathrm{CH}_{4} \mathrm{Flux}\right)+0.72, \mathrm{r}^{2}=0.80\right)$. 


\subsubsection{Temporal Variations in $\mathrm{CO}_{2}$ Fluxes}

Temporal variations in the various $\mathrm{CO}_{2}$ fluxes are shown in Figure 12. For both lawns and tussocks, $\mathrm{CO}_{2}$ uptake increased from DOY 193 to 206 after which $\mathrm{NEE}_{\max }$ and $\mathrm{GEP}_{\max }$ decreased in magnitude from DOY 211 to 227. During the period with maximum uptake (DOY 206-211), precipitation was minimal, water table decreased approximately $5 \mathrm{~cm}$ to a depth of $10 \mathrm{~cm}$ below the soil surface (Figure 5), and daily average air temperatures reached their maximum for the study period (Figure 6).

$\mathrm{ER}_{\mathrm{F}}$ was relatively constant through the sampling period but increased briefly on DOY 200 and 202 when static chamber measurements were not made (i.e. no $\mathrm{ER}_{\mathrm{S}}$ measurements). The interaction between lawn and tussock communities and time (RM ANOVA (Time)) was found to be significant for $\mathrm{NEE}_{\max }\left(\mathrm{F}_{10,5}=53.64, \mathrm{p}=0.0002\right)$, $\operatorname{GEP}_{\max }\left(\mathrm{F}_{10,5}=7.79, \mathrm{p}=0.01\right)$, and $\mathrm{ER}_{\mathrm{F}}\left(\mathrm{F}_{10,5}=71.64, \mathrm{p}=0.0001\right)$. However, only $\mathrm{ER}_{\mathrm{F}}$ trends were different for tussocks and lawns over time (RM ANOVA (Interaction): $F_{10,5}$ $=12.98, \mathrm{p}=0.006)($ Figure 12$)$. In contrast, $E R_{S}$ did not vary significantly over time (RM ANOVA (Time): $\mathrm{F}_{14,1}=107.32, \mathrm{p}=0.08$ ) and there was a similar lack of temporal variation for lawns and tussocks (RM ANOVA (Interaction): $\left.\mathrm{F}_{14,1}=6.90, \mathrm{p}=0.29\right)$. This lack of variation may be due to more similar environmental conditions during ERS sampling on cloudy days and having not sampled as often during the large loss period around DOY 200-205 when air and soil temperatures were greatest (Figure 6 \& Figure $12)$. 

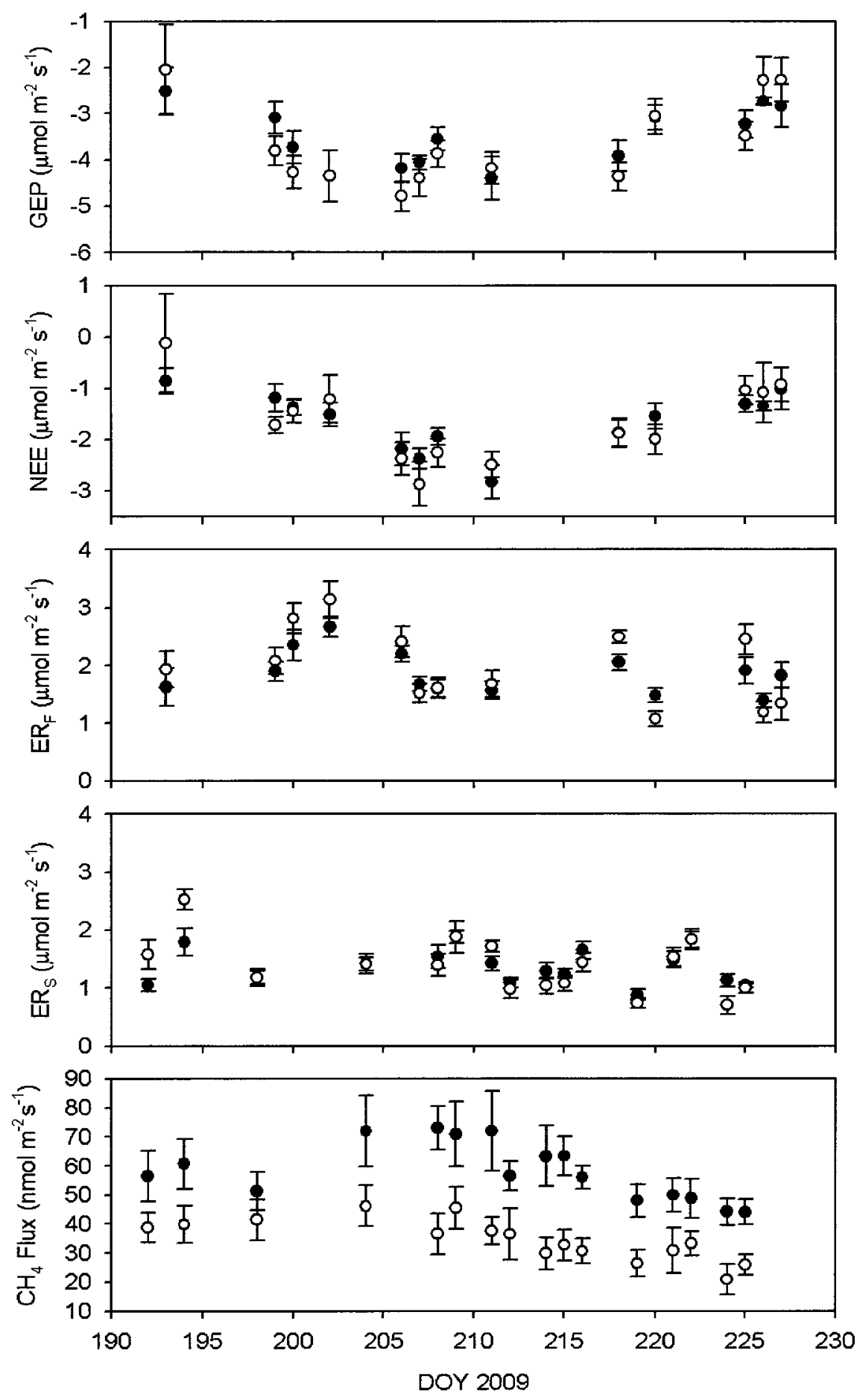

Figure 12. The average daily flux for lawns (closed circles) and tussocks (open circles) using the flow-through and opaque static chamber systems. Gross ecosystem production (GEP); net ecosystem exchange (NEE); ecosystem respiration (flow-through chamber) $\left(E R_{F}\right)$; ecosystem respiration (static chamber) $\left(E_{S}\right)$. Error bars represent $\pm 1 \mathrm{SE}$. The number of samples for each symbol is 8 . 
$\mathrm{NEE}_{\max }, \mathrm{GEP}_{\max }$, and $\mathrm{ER}_{\mathrm{F}}$ significantly correlated with $\mathrm{PAR}$ and soil temperature at $10 \mathrm{~cm}$ depth over the study period (Table 6). Both photosynthesis and respiration rates tended to increase for warmer sunnier conditions although uptake increased to a greater extent than loss such that $\mathrm{NEE}_{\max }$ was greater on these days. $\mathrm{NEE}_{\max }$ did not significantly correlate to any other ab iotic variable; whereas, $\mathrm{GEP}_{\max }, \mathrm{ER}_{\mathrm{F}}$, and $\mathrm{ER}_{\mathrm{S}}$ were found to significantly correlate to temperature at 2 and $5 \mathrm{~cm}$ depths and also with air temperature (Table 6). There were no significant correlations between $\mathrm{ER}_{\mathrm{F}}$ to water table depth or VWC; however, when lawns and tussocks were treated separately there was a significant correlation between $\mathrm{ER}_{\mathrm{F}}$ and water table depth and VWC (lawns: $\mathrm{r}=0.47, \mathrm{p}=$ 0.0001 and $\mathrm{r}=-0.21, \mathrm{p}=0.04$, respectively and tussocks: $\mathrm{r}=0.39, \mathrm{p}=0.0001$ and $\mathrm{r}=$ $0.29, \mathrm{p}=0.004$, respectively) (Figure 13), indicating that there were similar abiotic controls on $\mathrm{ER}_{\mathrm{F}}$ respiration within lawns and tussocks, but their relationships were different. This different response to water table and VWC may have caused lawn and tussock $\mathrm{ER}_{\mathrm{F}}$ to vary differently over time (RM ANOVA (interaction): $\mathrm{F}_{10,5}=12.98, \mathrm{p}=$ 0.006) (Figure 12).

Lawn and tussock $E_{S}$ correlated significantly to temperatures at 2 and $5 \mathrm{~cm}$ depths, air temperature, and $\mathrm{CH}_{4}$ flux $(\mathrm{r}=0.41, \mathrm{p}=0.0001$ and $\mathrm{r}=0.60, \mathrm{p}=0.0001$ respectively) (Table 7 \& Figure 14). Lawn $\mathrm{ER}_{\mathrm{S}}$ had a significant negative correlation to VWC while tussock ERs had a significant positive correlation to VWC (Table 7 \& Figure 14). Overall, $E R_{F}$ and $E R_{S}$ were found to be enhanced by warmer, moist, but not saturated soil conditions for both communities. 
Table 6. Spearman's rho correlation coefficients showing significant relationships between environmental variables and $\mathrm{CO}_{2}$ fluxes with p-values given in brackets. Net ecosystem exchange $\left(\mathrm{NEE}_{\max }\right)$; gros s ecosystem production $\left(\mathrm{GEP}_{\max }\right)$; ecosystem respiration (flow-through chamber) $\left(E_{F}\right)$; ecosystem resp iration (static chamber) $\left(E_{\mathrm{S}}\right)$.

\begin{tabular}{|c|c|c|c|c|}
\hline & $N E E_{\max }$ & $G E P_{\max }$ & $E \boldsymbol{R}_{F}$ & $E R_{S}$ \\
\hline Temperature $\left({ }^{\circ} \mathrm{C}\right)$ at $2 \mathrm{~cm}$ depth & & $\begin{array}{c}-0.26 \\
(0.0002)\end{array}$ & $\begin{array}{c}0.52 \\
(0.0001)\end{array}$ & $\begin{array}{c}0.62 \\
(0.0001)\end{array}$ \\
\hline Temperature $\left({ }^{\circ} \mathrm{C}\right)$ at $5 \mathrm{~cm}$ depth & & $\begin{array}{c}-0.23 \\
(0.0009)\end{array}$ & $\begin{array}{c}0.41 \\
(0.0001)\end{array}$ & $\begin{array}{c}0.48 \\
(0.0001)\end{array}$ \\
\hline Temperature $\left({ }^{\circ} \mathrm{C}\right)$ at $10 \mathrm{~cm}$ depth & $\begin{array}{c}-0.32 \\
(0.0001)\end{array}$ & $\begin{array}{c}-0.47 \\
(0.0001)\end{array}$ & $\begin{array}{c}0.34 \\
(0.0001)\end{array}$ & \\
\hline Air Temperature $\left({ }^{\circ} \mathrm{C}\right)$ & & $\begin{array}{c}-0.45 \\
(0.0001)\end{array}$ & $\begin{array}{c}0.59 \\
(0.0001)\end{array}$ & $\begin{array}{c}0.48 \\
(0.0001)\end{array}$ \\
\hline $\begin{array}{l}\text { Volumetric water content }(0-20 \mathrm{~cm}) \\
\left(\mathrm{m}^{3} \mathrm{~m}^{-3}\right) \\
\text { Water table depth }(\mathrm{cm})\end{array}$ & & & & 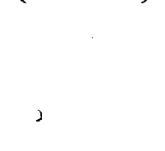 \\
\hline 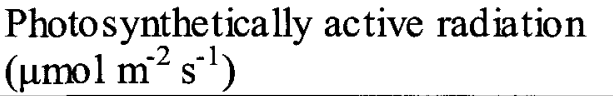 & $\begin{array}{l}-0.18 \\
(0.01)\end{array}$ & $\begin{array}{c}-0.36 \\
(0.0001)\end{array}$ & $\begin{array}{c}0.26 \\
(0.0002)\end{array}$ & \\
\hline
\end{tabular}

Table 7. Spearman's rho correlation coefficients showing significant relationships between environmental variables and ecosystem respiration (static chamber) (ER $)$, for lawn and tussock communities with p-values given in brackets.

\begin{tabular}{|c|c|c|}
\hline & $E R_{S} L a w n$ & ER $_{S}$ Tussock \\
\hline Temperature $\left({ }^{\circ} \mathrm{C}\right)$ at $2 \mathrm{~cm}$ depth & $0.60(0.0001)$ & $0.65(0.0001)$ \\
\hline Temperature $\left({ }^{\circ} \mathrm{C}\right)$ at $5 \mathrm{~cm}$ depth & $0.38(0.0001)$ & $0.60(0.0001)$ \\
\hline Temperature $\left({ }^{\circ} \mathrm{C}\right)$ at $10 \mathrm{~cm}$ depth & & \\
\hline Air Temperature $\left({ }^{\circ} \mathrm{C}\right)$ & $0.51(0.0001)$ & $0.45(0.0001)$ \\
\hline Volumetric water content $(0-20 \mathrm{~cm})\left(\mathrm{m}^{3} \mathrm{~m}^{-3}\right)$ & $-0.22(0.01)$ & $0.25(0.005)$ \\
\hline $\mathrm{CH}_{4}$ Flux $\left(\mathrm{nmol} \mathrm{m}^{-2} \mathrm{~s}^{-1}\right)$ & $0.41(0.0001)$ & $0.60(0.0001)$ \\
\hline
\end{tabular}



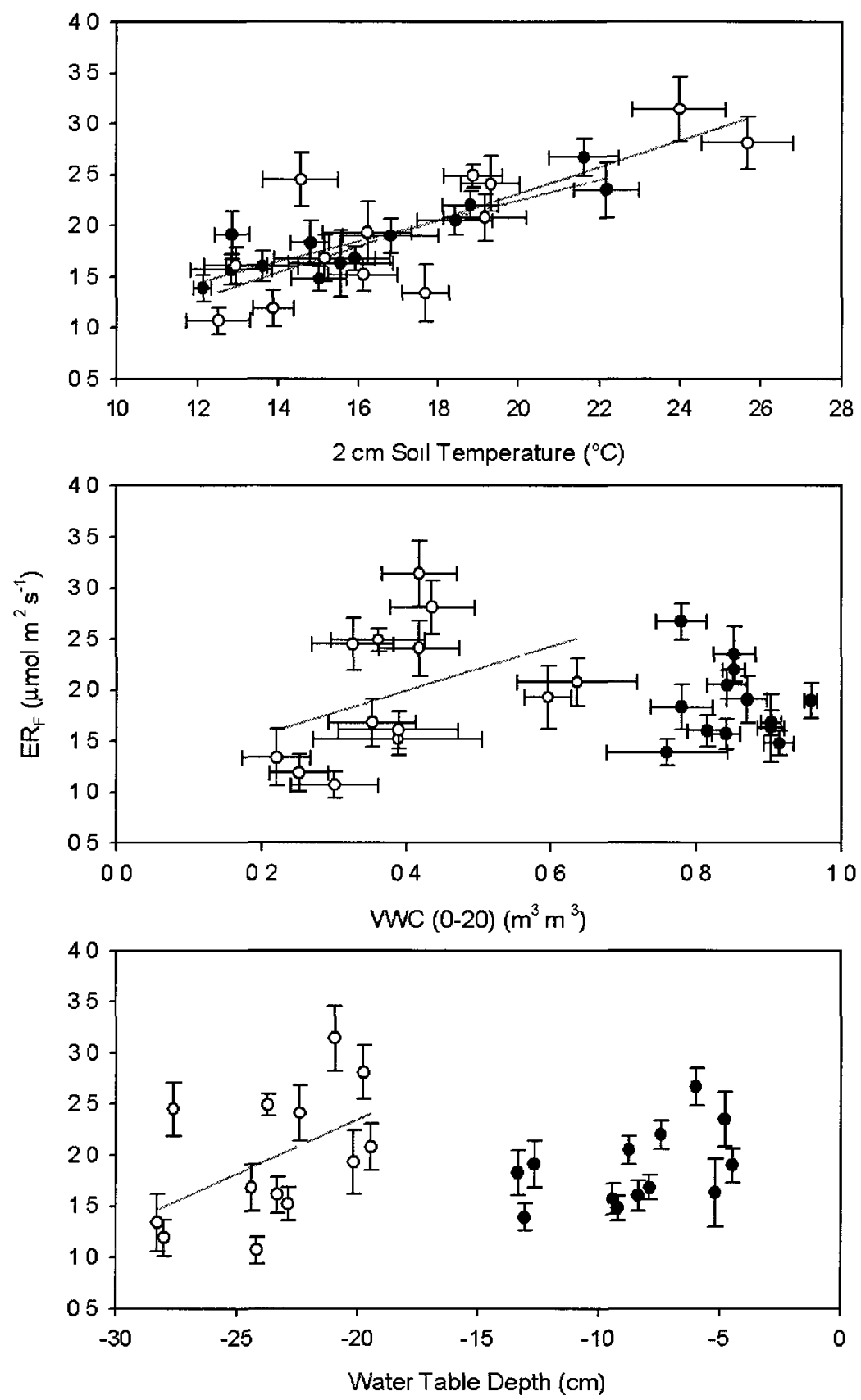

Figure 13. The relationship between ecosystem respiration (flow-through chamber), $\mathrm{ER}_{\mathrm{F}}$, and temperature at $2 \mathrm{~cm}$ depth (top panel), average volumetric water content (VWC) (middle panel), and water table depth (bottom panel). Closed circles represent lawns and open circles represent tussocks. Error bars represent $\pm 1 \mathrm{SE}$. The number of samples for each symbol is 8 . Lines are given for significant linear regressions. Top panel lawns $\left(E R_{F}=0.1\right.$ (Temperature) $\left.+0.24, r^{2}=0.77\right)$ and tussocks $\left(E_{F}=0.13\right.$ (Temperature) -0.27 , $\left.\mathrm{r}^{2}=0.64\right)$; middle panel $\left(\mathrm{ER}_{\mathrm{F}}=2.16(\right.$ Temperature $\left.)+1.13, \mathrm{r}^{2}=0.25\right)$; bottom panel $\left(E R_{\mathrm{F}}=\right.$ 0.11 (Temperature) $+2.89, \mathrm{r}^{2}=0.25$ ). 

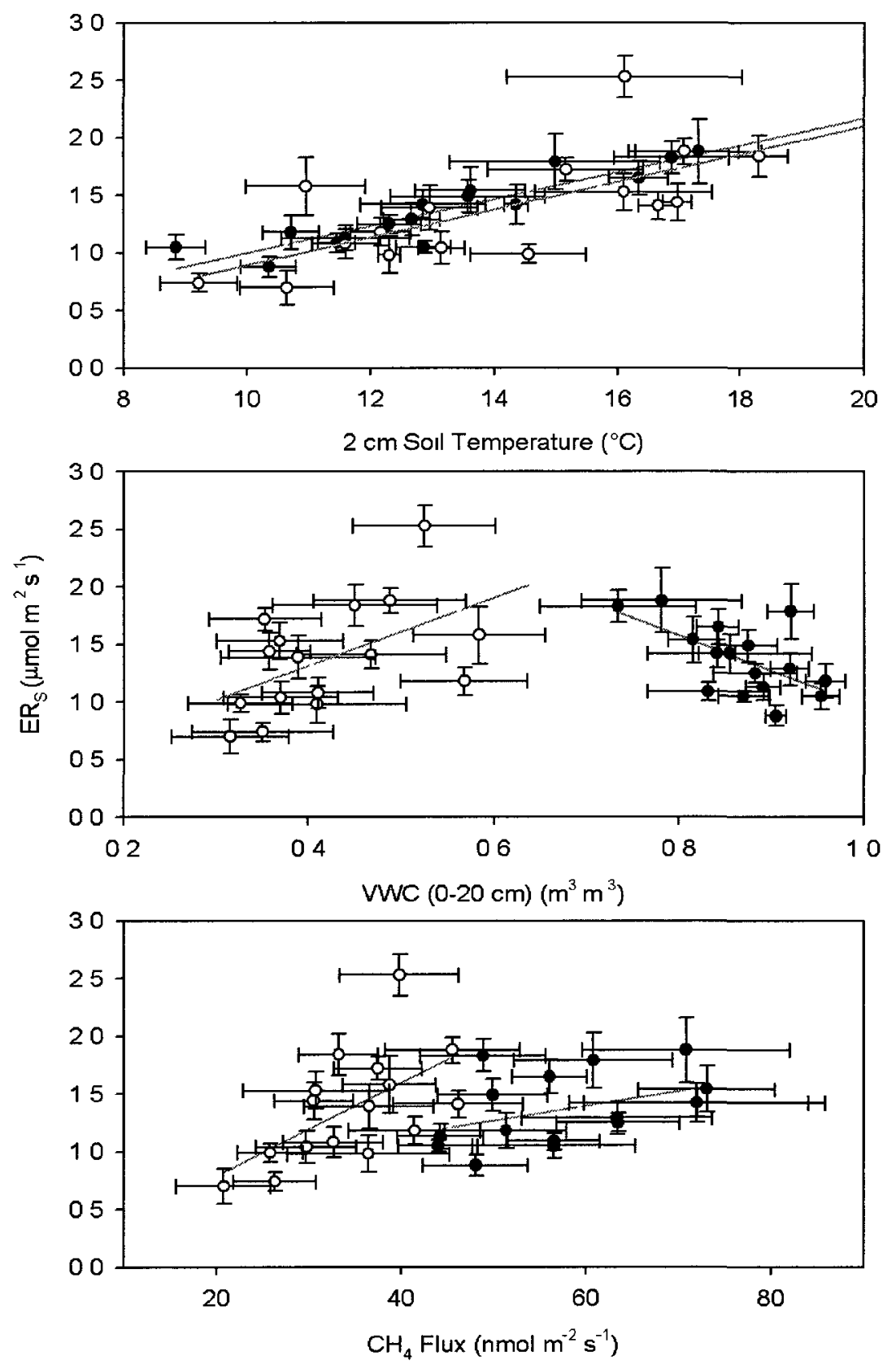

Figure 14. The relationship between ecosystem respiration (static chamber) (ERS) and temperature at $2 \mathrm{~cm}$ depth (top panel), average volumetric water content (VWC) (middle panel), and $\mathrm{CH}_{4}$ Flux (bottom panel). Closed circles represent lawns and open circles represent tussocks. Error bars represent $\pm 1 \mathrm{SE}$. The number of samples for each symbol is 8. Lines are given for significant linear regressions. Top panel (L: $E_{S}=0.12$ (Temperature) $-0.17, \mathrm{r}^{2}=0.82 ; \mathrm{T}: \mathrm{ER}_{\mathrm{S}}=0.07$ (Temperature) $+0.41, \mathrm{r}^{2}=0.37$ ), middle panel $\left(\mathrm{L}: \mathrm{ER}_{\mathrm{S}}=-3.04(\mathrm{VWC})+4.01, \mathrm{r}^{2}=0.36 ; \mathrm{T}: \mathrm{ER}_{\mathrm{S}}=2.54(\mathrm{VWC})+0.14, \mathrm{r}^{2}=0.27\right)$, bottom panel (L: $\mathrm{ER}_{\mathrm{S}}=0.01\left(\mathrm{CH}_{4} \mathrm{Flux}\right)+0.62, \mathrm{r}^{2}=0.28$; $\mathrm{T}: \mathrm{ER}_{\mathrm{S}}=0.04\left(\mathrm{CH}_{4} \mathrm{Flux}\right)-0.02$, $\left.r^{2}=0.36\right)$. 


\subsubsection{Temporal Variations in $\mathrm{CH}_{4}$ Fluxes}

Similar to $\mathrm{ER}_{\mathrm{S}}, \mathrm{CH}_{4}$ fluxes did not vary significantly over time (RM ANOVA (Time): $\mathrm{F}_{14,1}=7.38, \mathrm{p}=0.28$ ) and this lack of temporal variation was common for lawns and tussocks (RM ANOVA (Interaction): $\mathrm{F}_{14,1}=26.78, \mathrm{p}=0.15$ ). However, Figure 12 shows that $\mathrm{CH}_{4}$ fluxes, particularly for lawns, peaked around the same time as $\mathrm{GEP}_{\max }$ and $\mathrm{NEE}_{\max }$ after which, $\mathrm{CH}_{4}$ fluxes decreased. $\mathrm{CH}_{4}$ fluxes correlated positively and significantly with air temperature and water table within and among lawns and tussocks (Table 8). Tussock $\mathrm{CH}_{4}$ fluxes were positively correlated to $\mathrm{VWC}(\mathrm{r}=0.38, \mathrm{p}=0.0001)$; whereas, lawn $\mathrm{CH}_{4}$ fluxes were not $(\mathrm{r}=0.003, \mathrm{p}=0.997)$. Lawns had mostly saturated conditions throughout the field study (Figure 7) and precipitation had little effect on $\mathrm{CH}_{4}$ fluxes. In comparison, as tussock VWC decreased over time (Figure 5) so too did rates of $\mathrm{CH}_{4}$ flux (Figure 12). $\mathrm{CH}_{4}$ fluxes correlated significantly and positively with soil temperature at $10 \mathrm{~cm}$ depth within lawns; however, not within tussocks (Table 8 \& Figure 15). This may be a result of lawns being saturated at $10 \mathrm{~cm}$ depth for most of the field season (Figure 5) and thus this depth is near the zone of maximum $\mathrm{CH}_{4}$ production. Tussock $\mathrm{CH}_{4}$ fluxes instead correlated significantly and positively to soil temperature at shallower depths ( 2 and $5 \mathrm{~cm}$ ) (Table $8 \&$ Figure 15) where temperatures were significantly higher (Table 2). Overall, $\mathrm{CH}_{4}$ fluxes within lawns and tussocks seem to increase with warmer air and soil conditions, greater VWC, and higher water table. Lawns emitted significantly more $\mathrm{CH}_{4}$ (Table 5) likely due to less $\mathrm{CH}_{4}$ oxidation within a reduced aerobic zone and possibly due to warmer temperatures at the depth where the peat was saturated (as this depth was effectively closer to the surface). 
Table 8. Spearman's rho correlation coefficients showing significant relationships between environmental variables and $\mathrm{CH}_{4}$ flux for lawn and tussock communities separately and combined with significant $\mathrm{p}$-values given in brackets.

\begin{tabular}{l|ccc}
\hline & Lawn & Tussock & $\begin{array}{c}\text { Lawn and } \\
\text { Tussock }\end{array}$ \\
\hline Temperature $\left({ }^{\circ} \mathrm{C}\right)$ at $2 \mathrm{~cm}$ depth & & $0.30(0.0008)$ & \\
Temperature $\left({ }^{\circ} \mathrm{C}\right)$ at $5 \mathrm{~cm}$ depth & & $0.29(0.001)$ & \\
Temperature $\left({ }^{\circ} \mathrm{C}\right)$ at $10 \mathrm{~cm}$ depth & $0.20(0.02)$ & & \\
Air Temperature $\left({ }^{\circ} \mathrm{C}\right)$ & $0.25(0.005)$ & $0.20(0.03)$ & $0.19(0.003)$ \\
Volumetric water content $(0-20$ & & $0.38(0.0001)$ & $0.53(0.0001)$ \\
$\mathrm{cm})\left(\mathrm{m}^{3} \mathrm{~m}^{-3}\right)$ & & & \\
Water table $(\mathrm{cm})$ & $0.21(0.02)$ & $0.29(0.0009)$ & $0.56(0.0001)$ \\
\hline
\end{tabular}



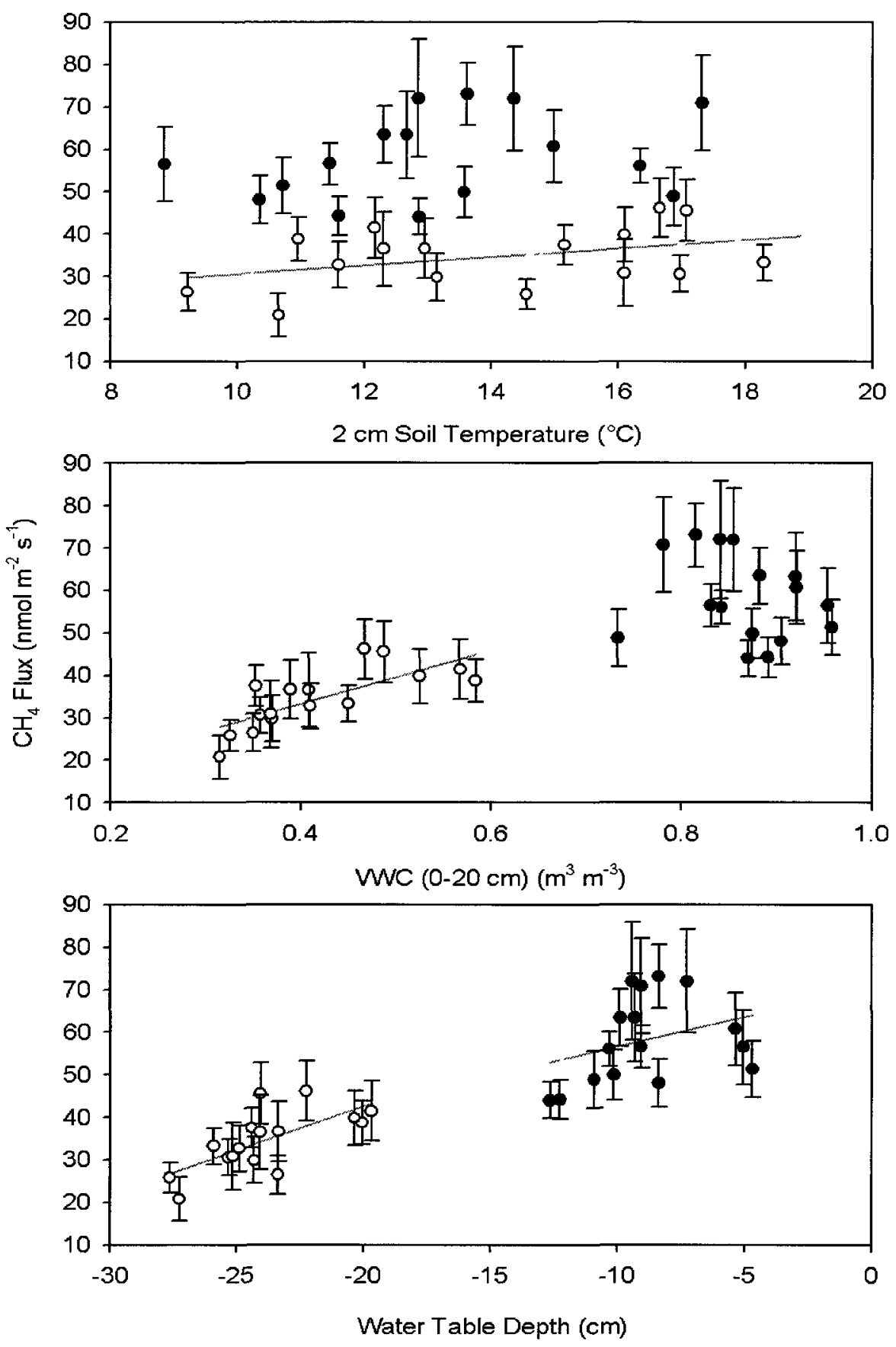

Figure 15. The relationship between $\mathrm{CH}_{4}$ flux and temperature at $2 \mathrm{~cm}$ depth (top panel), average volumetric water content (VWC) (middle panel), and water table depth (bottom panel). Error bars represent $\pm 1 \mathrm{SE}$. The number of samples for each symbol is 8 . Lines are given for significant linear regressions. Top panel $\left(\mathrm{CH}_{4} \mathrm{Flux}=1.01\right.$ (Temperature $)+$ $\left.20.5, \mathrm{r}^{2}=0.15\right)$, middle panel $\left(\mathrm{CH}_{4} \mathrm{Flux}=63.16(\mathrm{VWC})+7.97, \mathrm{r}^{2}=0.57\right)$, bottom panel $\left(\mathrm{L}: \mathrm{CH}_{4} \mathrm{Flux}=1.39(\mathrm{WT})+70.54, \mathrm{r}^{2}=0.17 ; \mathrm{T}: \mathrm{CH}_{4} \mathrm{Flux}=2.07(\mathrm{WT})+52.94, \mathrm{r}^{2}=0.47\right)$. 


\subsection{General Seasonal Tre nds in $\mathrm{CH}_{4}$ and $\mathrm{CO}_{2}$ Exchange}

Seasonal variations in daily daytime $\mathrm{CH}_{4}$ flux and NEE measured using chamber and EC techniques showed similar patterns but relatively large differences in magnitude (Figure 16). Seasonal peaks of $\mathrm{CH}_{4}$ release and $\mathrm{CO}_{2}$ uptake occurred around the same time (DOY $201-215$ ) (July 20 - Aug 3) during the study. This period saw seasonal highs for air temperature, $5 \mathrm{~cm}$ soil temperature, and average daily PAR (Figure 6).

Maximum daytime losses of $\mathrm{CH}_{4}$ from the fen, measured by the $\mathrm{EC}$ system were approximately $40-55 \mathrm{nmol} \mathrm{m} \mathrm{m}^{-2} \mathrm{~s}^{-1}$ during mid-summer. Methane fluxes before and after this time declined to a low of approximately $20 \mathrm{nmol} \mathrm{m}^{-2} \mathrm{~s}^{-1}$ (Figure 16). Generally, chamber $\mathrm{CH}_{4}$ fluxes from the sedge lawn and tussock areas were considerably larger ranging from $20-80 \mathrm{nmol} \mathrm{m}^{-2} \mathrm{~s}^{-1}$. However, the EC fluxes may have been reflecting contributions from communities other than the lawn and tussock areas such as the shrub mounds NW of the tower (Figure 3) where $\mathrm{CH}_{4}$ emissions were negligible (data shown in Figure 16 from Piquette (2010)), which constituted approx $27 \%$ of the area within sector $3(70-100 \mathrm{~m})$.

Maximum daytime uptake of $\mathrm{CO}_{2}$ measured by the $\mathrm{EC}$ system peaked with fluxes of approximately -4 to $-5.5 \mu \mathrm{mol} \mathrm{m} \mathrm{m}^{-2} \mathrm{~s}^{-1}$ during mid-summer. $\mathrm{CO}_{2}$ fluxes before and after this time declined to a low of approximately $-2 \mu \mathrm{mol} \mathrm{m} \mathrm{m}^{-2} \mathrm{~s}^{-1}$. Overall, the magnitude of chamber NEE fluxes from the sedge lawn and tussock areas were considerably smaller ranging from approximately -1 to $-3 \mu \mathrm{mol} \mathrm{m} \mathrm{m}^{-2} \mathrm{~s}^{-1}$ while NEE on the peat shrub mounds was considerably larger at -7 to $-8 \mu \mathrm{mol} \mathrm{m} \mathrm{m}^{-2} \mathrm{~s}^{-1}$ (Piquette, 2010). 
Day to day variations in daily average $\mathrm{CH}_{4}$ flux were relatively large compared to the day to day variations in NEE (F igure 16). The factors that influence this short-term variability in day-to-day $\mathrm{CH}_{4}$ and $\mathrm{CO}_{2}$ flux are discussed in the following section. 

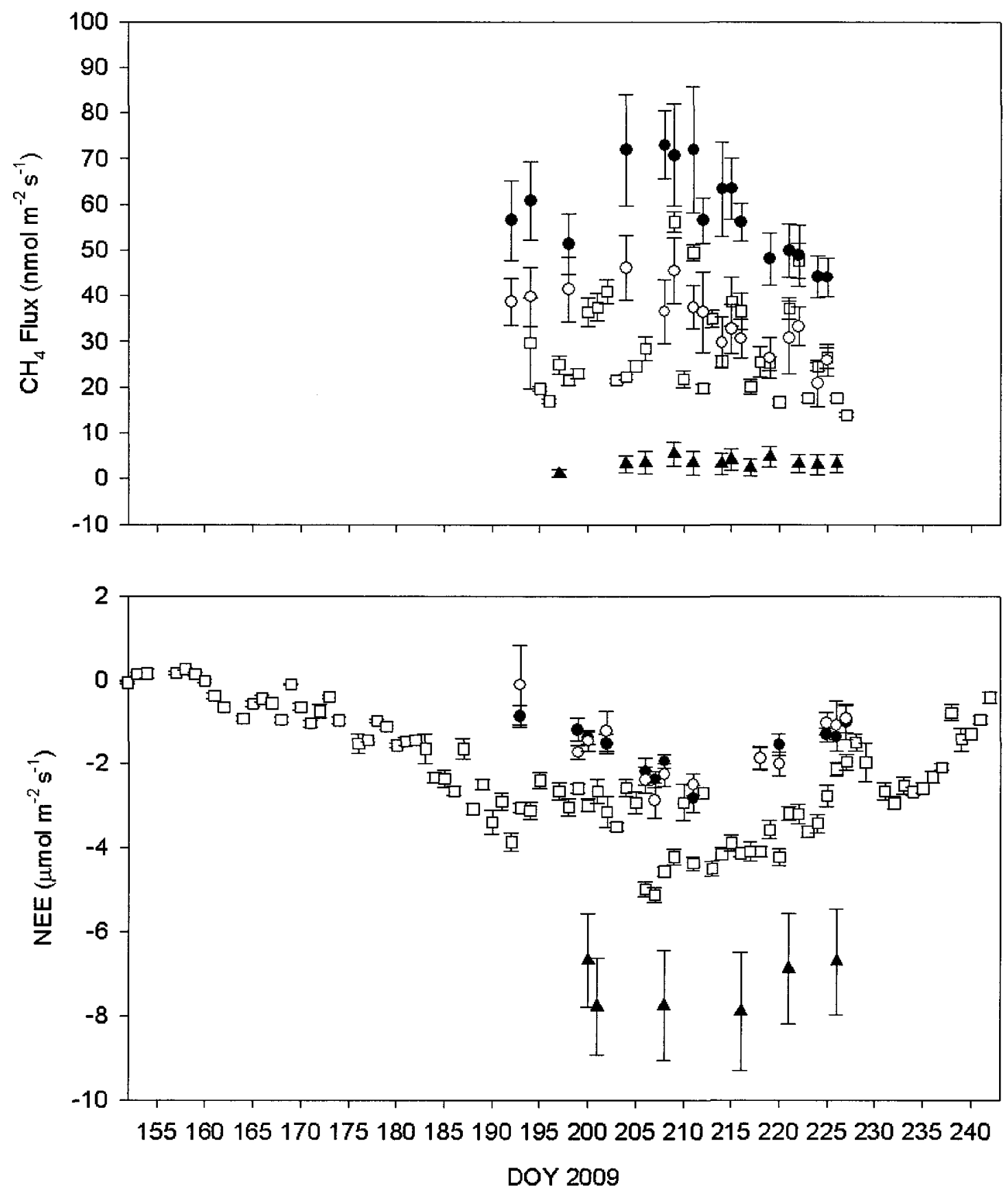

Figure 16. Daily daytime (10 am - $6 \mathrm{pm})$ average eddy covariance and chamber measurements of $\mathrm{CH}_{4}$ flux and net ecosystem exchange $\mathrm{CO}_{2}$ (NEE). Eddy covariance fluxes are shown for days when there were at least 6 half hours with good quality measurements. Chamber fluxes are means of 8 different collar measurements for each plotted day. Error bars represent $\pm 1 \mathrm{SE}$. Chamber fluxes are represented by closed circles for lawns, open circles for tussocks, triangles for shrub peat mounds, and open squares represent tower fluxes. 


\subsubsection{Daily Variation in Ecosystem $\mathrm{CH}_{4}$ and $\mathrm{CO}_{2}$ Exchange}

Daily daytime $\mathrm{CH}_{4}$ flux measured using the EC system had a significant positive relationship with $5 \mathrm{~cm}$ soil temperature described here using an exponential relationship where $\mathrm{CH}_{4} \mathrm{Flux}=18.16^{*} 3.43^{((\mathrm{Temp}-10) / 10))}(\mathrm{RMSE}=4.95, \mathrm{p}=0.01)$ and a significant negative relationship with $u *$ fitted using a linear regression where $\mathrm{CH}_{4}$ Flux $=-6.57(\mathrm{u} *)$ $+4.53\left(r^{2}=0.3, p=0.01\right)($ Figure 17). Note, there was no significant correlation between $5 \mathrm{~cm}$ soil temperature and $\mathrm{u} *$. In comparison, daily daytime NEE was not related to those two variables but had a significant negative relationship with PAR $(r=-0.45, p=0.0009)$ (Figure 18), illustrating an increase in $\mathrm{CO}_{2}$ uptake rates with sunnier conditions. This relationship between NEE and PAR was improved when grouped by air temperature (temperature $<12^{\circ} \mathrm{C}(\mathrm{r}=-0.31, \mathrm{p}=0.12)$, temperature $>12^{\circ} \mathrm{C}(\mathrm{r}=-0.52, \mathrm{p}=0.006)$, illustrating a greater dependence of NEE on PAR when temperature was high (Figure $18)$. 

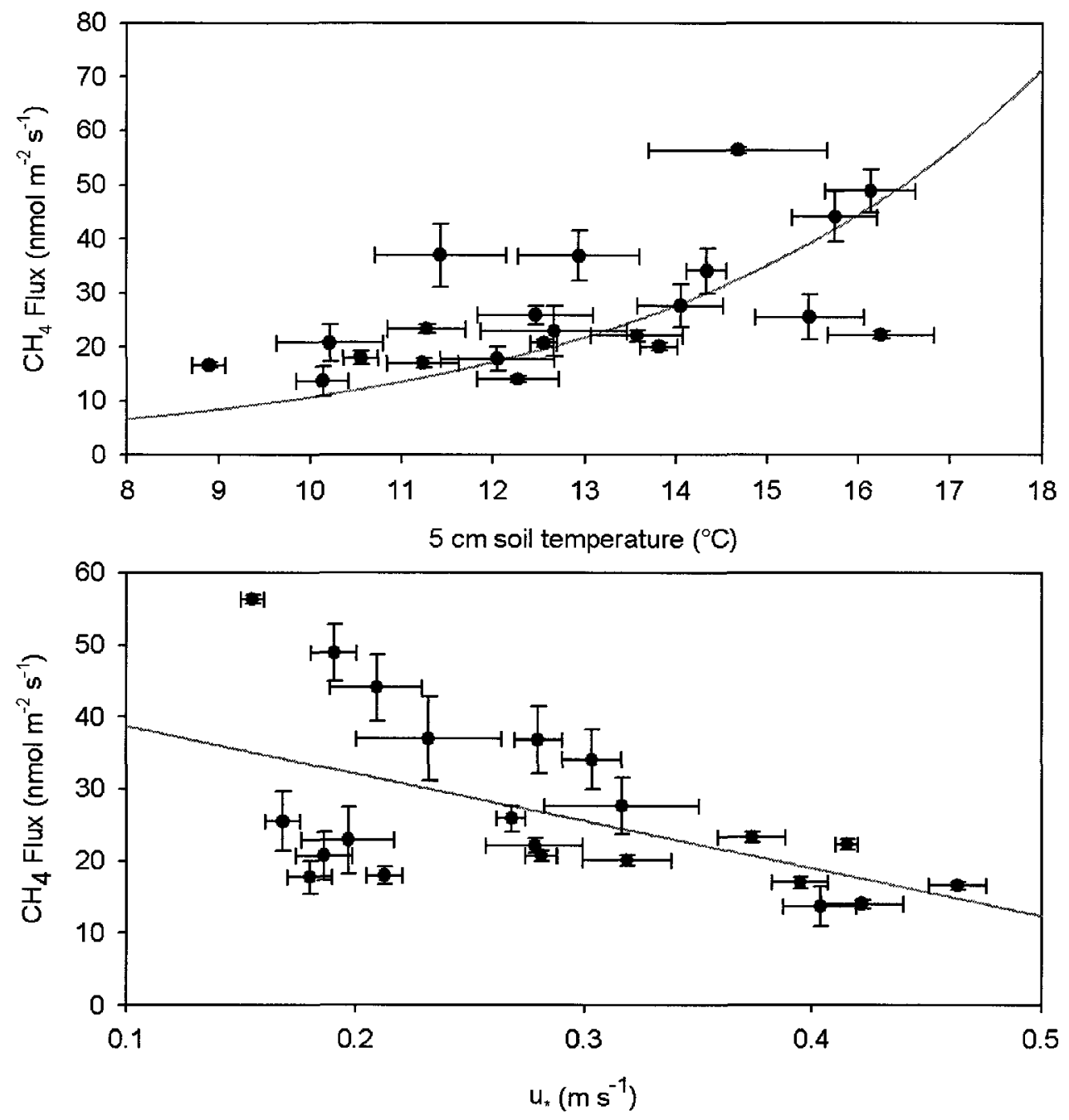

Figure 17. The relationship between daily daytime $(10 \mathrm{am}-6 \mathrm{pm}) \mathrm{CH}_{4}$ flux and $5 \mathrm{~cm}$ soil temperature (top panel) and friction velocity ( $\mathrm{u}_{*}$ ) (bottom panel). Error bars represent \pm 1 SE. The number of $30 \mathrm{~min}$ fluxes for each symbol ranges from 6 to 16 . 

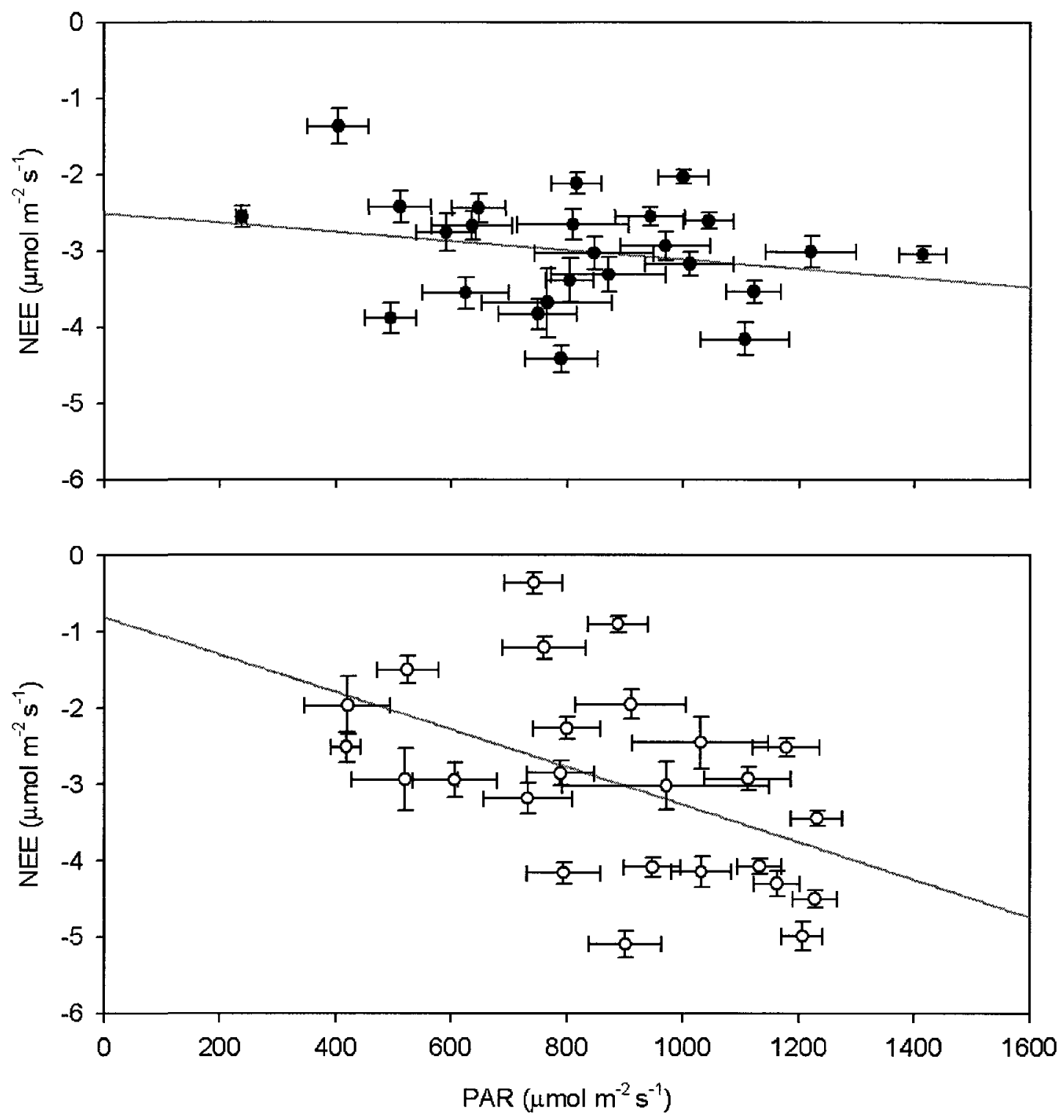

Figure 18 . The relationship between daily daytime $(10 \mathrm{am}-6 \mathrm{pm})$ net ecosystem exchange of $\mathrm{CO}_{2}$ (NEE) and photosynthetically active radiation (PAR). The top panel illustrates the relationship for air temperature below $12^{\circ} \mathrm{C}$ and the bottom panel is for air temperature above $12^{\circ} \mathrm{C}$. Lines are given for significant linear regressions. Top Panel: $\left(\mathrm{NEE}=-0.0006(\mathrm{PAR})-2.52, \mathrm{r}^{2}=0.05\right)$ and bottom panel: $\left(\mathrm{NEE}=-0.003-0.81, \mathrm{r}^{2}=0.25\right)$. Error bars represent $\pm 1 \mathrm{SE}$. The number of 30 min fluxes for each symbol ranges from 6 to 16 . 


\subsubsection{Diurnal Variation in Ecosystem $\mathrm{CH}_{4}$ and $\mathrm{CO}_{2}$ Flux}

Figure 19 shows the average diurnal variation in $30 \mathrm{~min}^{\mathrm{CH}_{4}}$ flux during three different characteristic turbulence conditions. The first column in Figure 19 shows diurnal variation of $\mathrm{CH}_{4}$ flux during days with consistently turbulent conditions, the second column are days with consistently calm conditions, and the third column are days with mixed conditions. During turbulent conditions, $\mathrm{CH}_{4}$ flux was consistently low throughout the day (Figure 19, column 1) regardless of temperature; however, during relatively calm conditions, $\mathrm{CH}_{4}$ varied with $5 \mathrm{~cm}$ soil temperature tending to peak in the evening (Figure 19, column 2). When $\mathrm{u} *$ and temperature both varied diurnally, $\mathrm{CH}_{4}$ flux also varied from low to high values depending on the magnitude of $u *$ and temperature (Figure 19, column 3). The effect of $\mathrm{u} *$ and $5 \mathrm{~cm}$ soil temperature on $30 \mathrm{~min} \mathrm{CH}_{4}$ flux is also shown in Figure 20. When temperature remained below $12{ }^{\circ} \mathrm{C}, \mathrm{CH}_{4}$ flux tended to be low (typically less than $30 \mathrm{nmol} \mathrm{m}^{-2} \mathrm{~s}^{-1}$ ). Above $12{ }^{\circ} \mathrm{C}, \mathrm{CH}_{4}$ flux was more variable with values as high as 50 to $75 \mathrm{nmol} \mathrm{m} \mathrm{s}^{-2}$ when $\mathrm{u} *$ was low (less than $0.24 \mathrm{~m} \mathrm{~s}^{-1}$ ) but still above $0.1 \mathrm{~m} \mathrm{~s}^{-1}$. Above $\mathrm{u} *$ of $0.24 \mathrm{~m} \mathrm{~s}^{-1}, \mathrm{CH}_{4}$ flux was similar regardless of temperature (Figure 20). Figure 21 again shows how this $\mathrm{u} *$ threshold of $0.24 \mathrm{~m} \mathrm{~s}^{-1}$ influences the relationship between $\mathrm{CH}_{4}$ flux and $5 \mathrm{~cm}$ soil temperature. Only when $\mathrm{u} *$ is low does $\mathrm{CH}_{4}$ flux notably increase with temperatures above $12{ }^{\circ} \mathrm{C}$. 

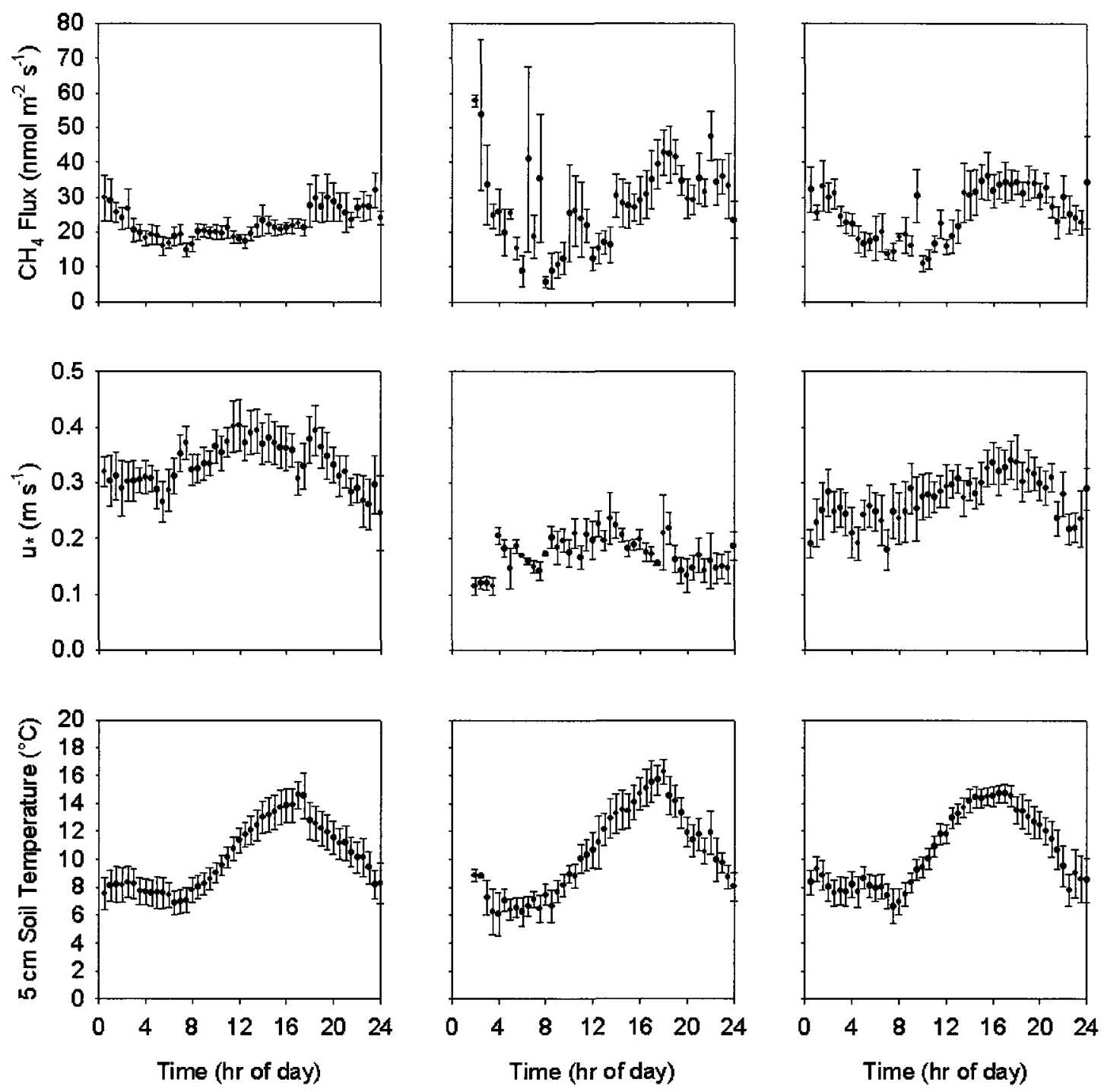

Figure 19. Diurnal variation of $\mathrm{CH}_{4}$ flux, friction velocity ( $\left.\mathrm{u} *\right)$, and $5 \mathrm{~cm}$ soil temperature for days with different turbulence conditions. Column 1 represents whole days $(14<$ half-hour measurements < 49) when mean $\mathrm{u} *$ was above $0.24 \mathrm{~m} \mathrm{~s}^{-1}$ and the standard deviation (SD) was below $0.07 \mathrm{~m} \mathrm{~s}^{-1}$, column 2 represents $\mathrm{u} *$ below $0.24 \mathrm{~m} \mathrm{~s}^{-1}$ and the SD was below $0.07 \mathrm{~m} \mathrm{~s}^{-1}$, and column 3 represents mixed $\mathrm{u} *$ (all other days) with a SD above $0.07 \mathrm{~m} \mathrm{~s}^{-1}$. Half-hour measurements with $\mathrm{u} *$ below $0.1 \mathrm{~m} \mathrm{~s}^{-1}$ were not included. Error bars represent $\pm 1 \mathrm{SE}$. The number of $30 \mathrm{~min}$ measurements for each symbol ranges from 10 to 21 . 


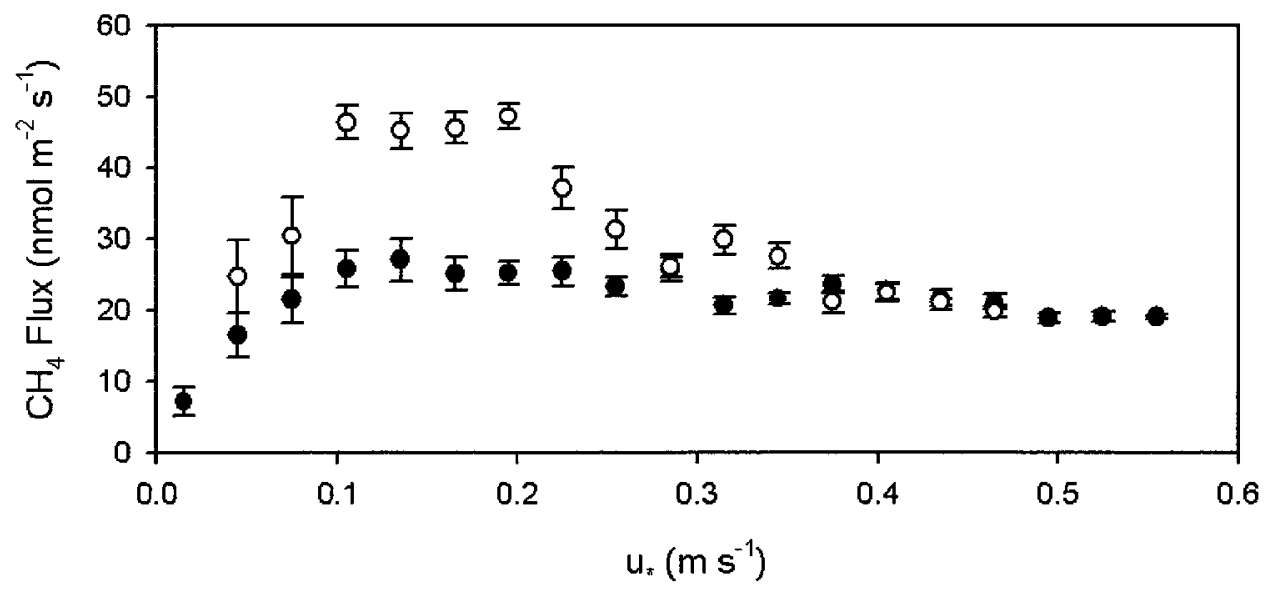

Figure 20. The relationship between $30 \mathrm{~min} \mathrm{CH}_{4}$ flux and frictional velocity, $\mathrm{u}$ *. Data are binned by $\mathrm{u} *\left(0.03 \mathrm{~m} \mathrm{~s}^{-1}\right.$ wide) and separated by temperature above (open circles) and below (closed circles) $12{ }^{\circ} \mathrm{C}$. Error bars represent $\pm 1 \mathrm{SE}$. The number of $30 \mathrm{~min}$ fluxes for each symbol ranges from 6 to 53 .

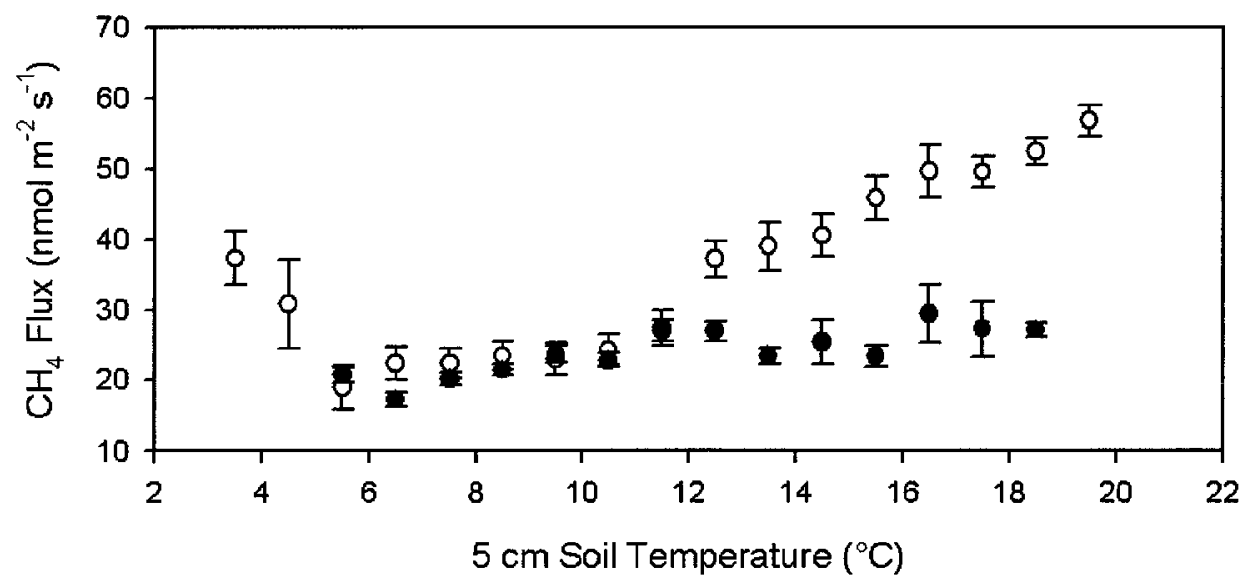

Figure 21. The relationship between $30 \mathrm{~min} \mathrm{CH}_{4}$ flux and $5 \mathrm{~cm}$ soil temperature. Data is binned by temperature $\left(0.5^{\circ} \mathrm{C}\right)$ and separated by $\mathrm{u} *$. Open circles represent data below $0.24 \mathrm{~m} \mathrm{~s}^{-1}$ and closed circles represent data above $0.24 \mathrm{~m} \mathrm{~s}^{-1}$. Error bars represent $\pm 1 \mathrm{SE}$. The number of $30 \mathrm{~min}$ fluxes for each symbol ranges from 5 to 58 . 
Based on the observation that $\mathrm{CH}_{4}$ flux only responds to temperature variations above $12{ }^{\circ} \mathrm{C}$ and that this response depends on $\mathrm{u} *$ (Figure 20 \& Figure 21), we identified two distinct groups of $\mathrm{CH}_{4}$ fluxes when $5 \mathrm{~cm}$ soil temperature was above $12^{\circ} \mathrm{C}$. Group 1 consisted of fluxes above $30 \mathrm{nmol} \mathrm{m} \mathrm{m}^{-2}$, which were associated with low $\mathrm{u} *$. Group 2 consisted of fluxes below $30 \mathrm{nmol} \mathrm{m}^{-2} \mathrm{~s}^{-1}$, which were associated with high $\mathrm{u}$ *. These two groups of $30 \mathrm{~min} \mathrm{CH}_{4}$ flux were tested for relationships with variables commonly associated with temporal variations in $\mathrm{CH}_{4}$ exchange (Table 9 \& Figure 22). $\mathrm{CH}_{4}$ flux below $30 \mathrm{nmol} \mathrm{m}^{-2} \mathrm{~s}^{-1}$ correlated negatively to latent heat flux and PAR; whereas, $\mathrm{CH}_{4}$ flux above $30 \mathrm{nmol} \mathrm{m} \mathrm{m}^{-2} \mathrm{~s}^{-1}$ correlated positively to VPD and $5 \mathrm{~cm}$ soil temperature (Table 9). For both groups combined, $\mathrm{CH}_{4}$ fluxes correlated positively and significantly to VPD and $5 \mathrm{~cm}$ soil temperature and correlated negatively to PAR, friction velocity, and ecosystem conductance. No significant correlations were found for water table depth or stability.

Table 9. Spearman's rho correlation coefficients showing significant relationships between $\mathrm{CH}_{4}$ flux and environmental variables for flux values above $12{ }^{\circ} \mathrm{C}$. $\mathrm{P}$ - values are given in brackets and considered significant when $\mathrm{p}<0.05$.

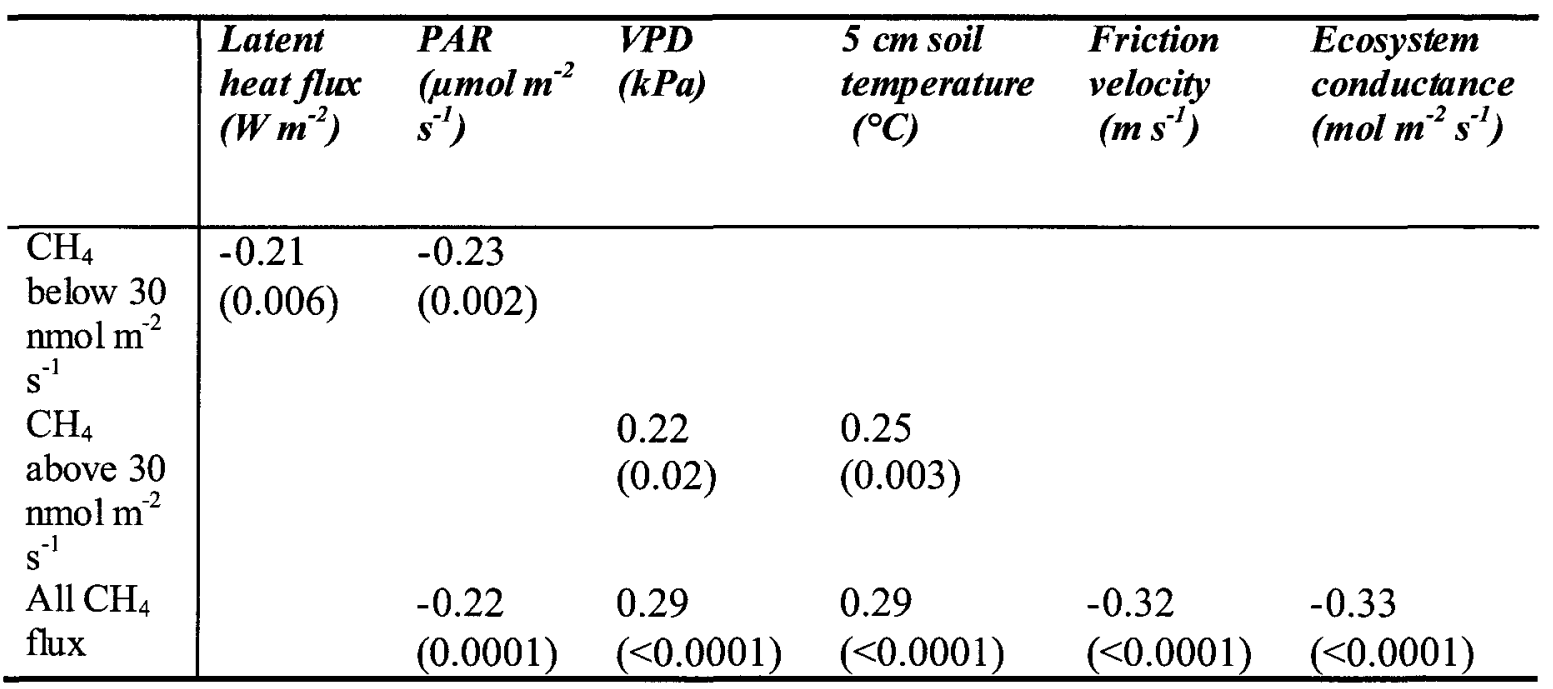



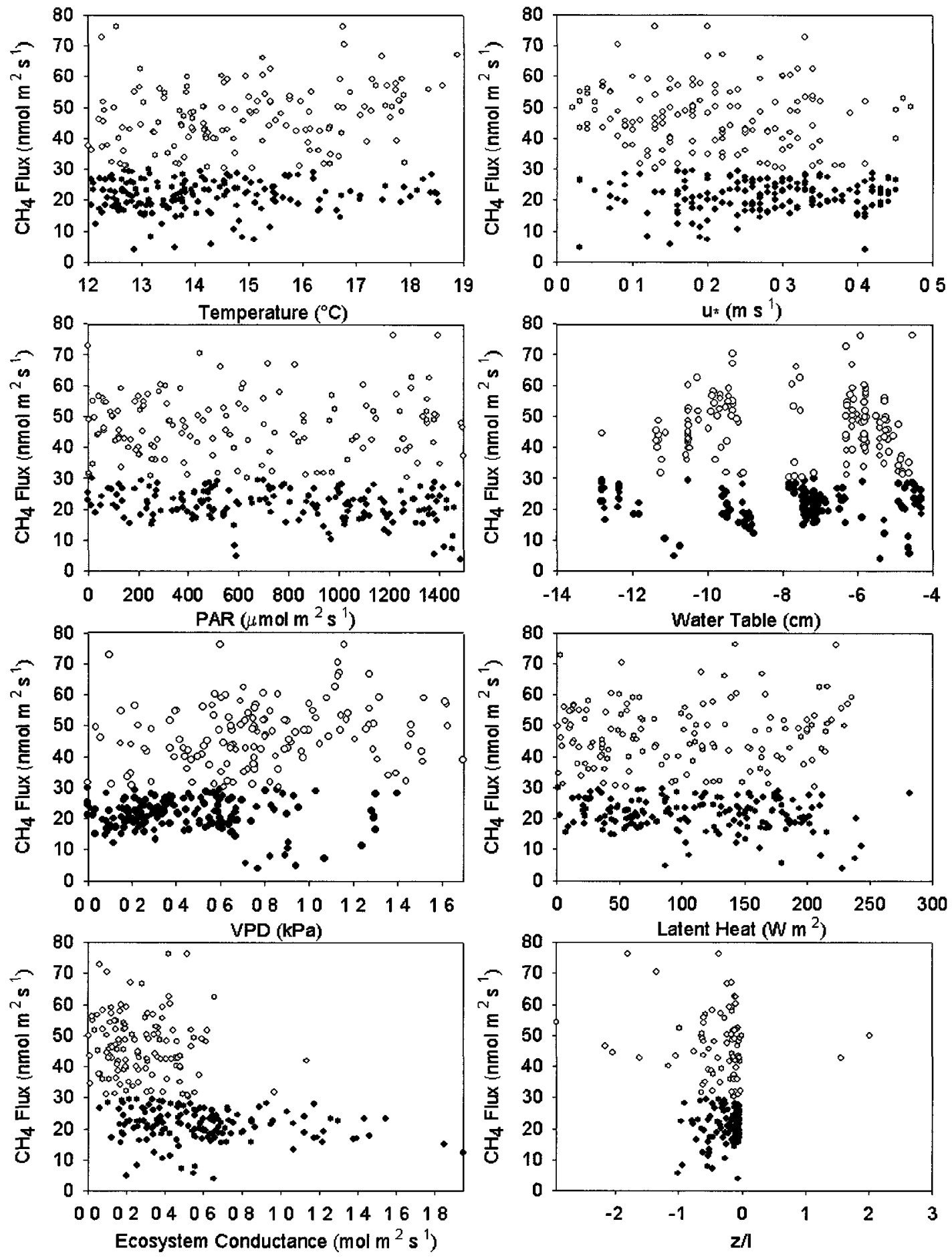

Figure 22. The relationshp between $30 \mathrm{~min} \mathrm{CH}_{4}$ flux and all variables above $12{ }^{\circ} \mathrm{C}$ separated by $\mathrm{CH}_{4}$ flux above and below $30 \mathrm{nmol} \mathrm{m}^{-2} \mathrm{~s}^{-1}$. Closed curcles represent $\mathrm{CH}_{4}$ flux below $30 \mathrm{nmol} \mathrm{m}^{-2} \mathrm{~s}^{-1}$ and open circles represent $\mathrm{CH}_{4}$ flux above $30 \mathrm{nmol} \mathrm{m}^{2} \mathrm{~s}^{-1}$ 
Above the generally accepted $\mathrm{u} *$ threshold of $0.1 \mathrm{~m} \mathrm{~s}^{-1}$, nighttime $\mathrm{NEE}\left(\mathrm{CO}_{2}\right.$ efflux) remained relatively constant particularly when $5 \mathrm{~cm}$ soil temperature remained below $8.5^{\circ} \mathrm{C}$ (Figure 23). Greater $\mathrm{CO}_{2}$ efflux was expected during warmer conditions as it influences both rates of plant and microbial respiration. Daytime 30 minute averages of NEE cannot be used to assess the influence of $\mathrm{u} *$ because short-term variation is heavily influenced by PAR (Figure 24). This relationship between NEE and PAR is described using a rectangular hyperbolic relationship that highlights rapid increase in $\mathrm{CO}_{2}$ sequestration at low light levels while at higher light levels, $\mathrm{CO}_{2}$ uptake approaches an asymptotic value $\left(\mathrm{GP}_{\max }\right)$ as light saturation occurs.

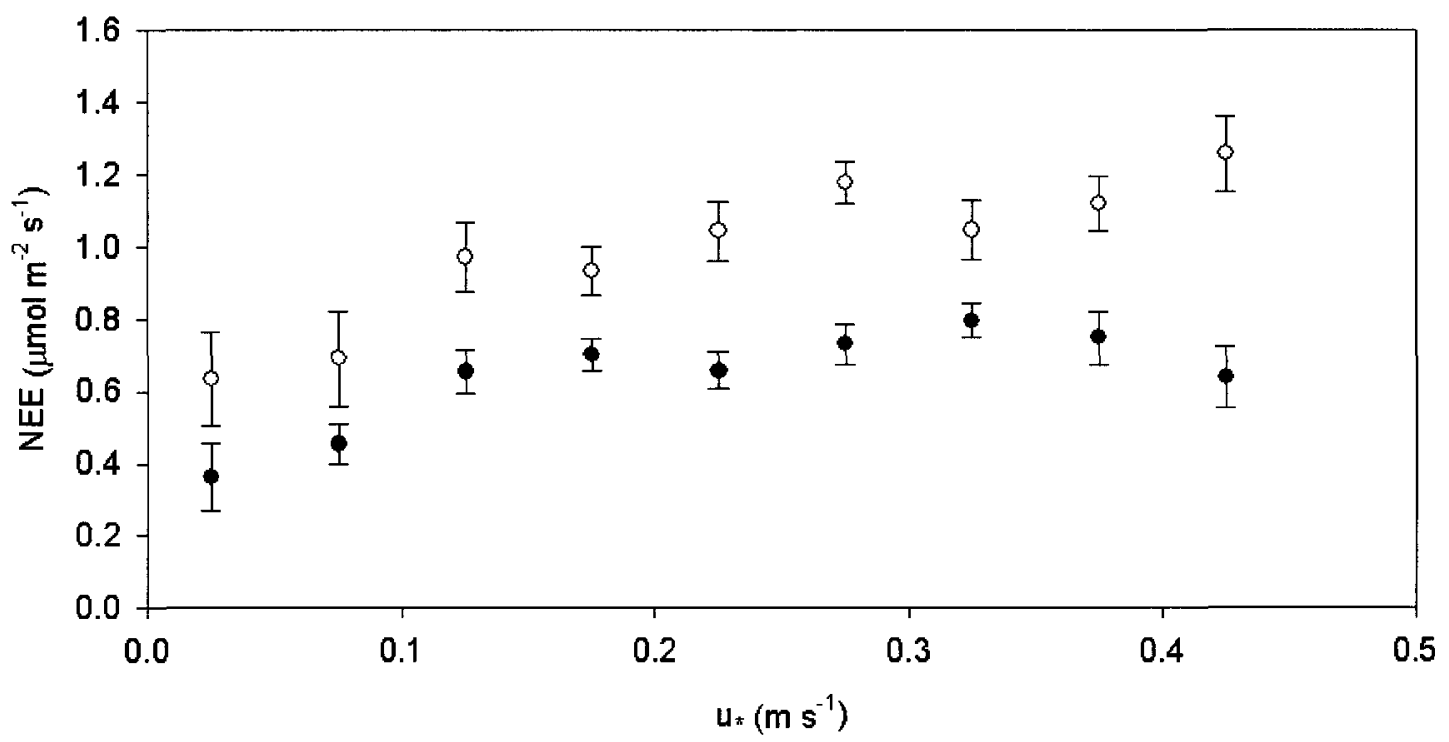

Figure 23. The relationship between nighttime (PAR less than $20 \mu \mathrm{mol} \mathrm{m} \mathrm{m}^{-2} \mathrm{~s}^{-1}$ ) net ecosystem exchange of $\mathrm{CO}_{2}, \mathrm{NEE} \mathrm{CO}_{2}$, and frictional velocity, $\mathrm{u} *$. Data are binned by $\mathrm{u} *$ $\left(0.05 \mathrm{~m} \mathrm{~s}^{-1}\right.$ wide) and separated by temperature above (open circles) and below (closed circles) $8.5^{\circ} \mathrm{C}$. Positive values indicate net ecosystem carbon loss. Error bars represent $\pm 1 \mathrm{SE}$. The number of samples for each symbol ranges from 18 to 70 . 


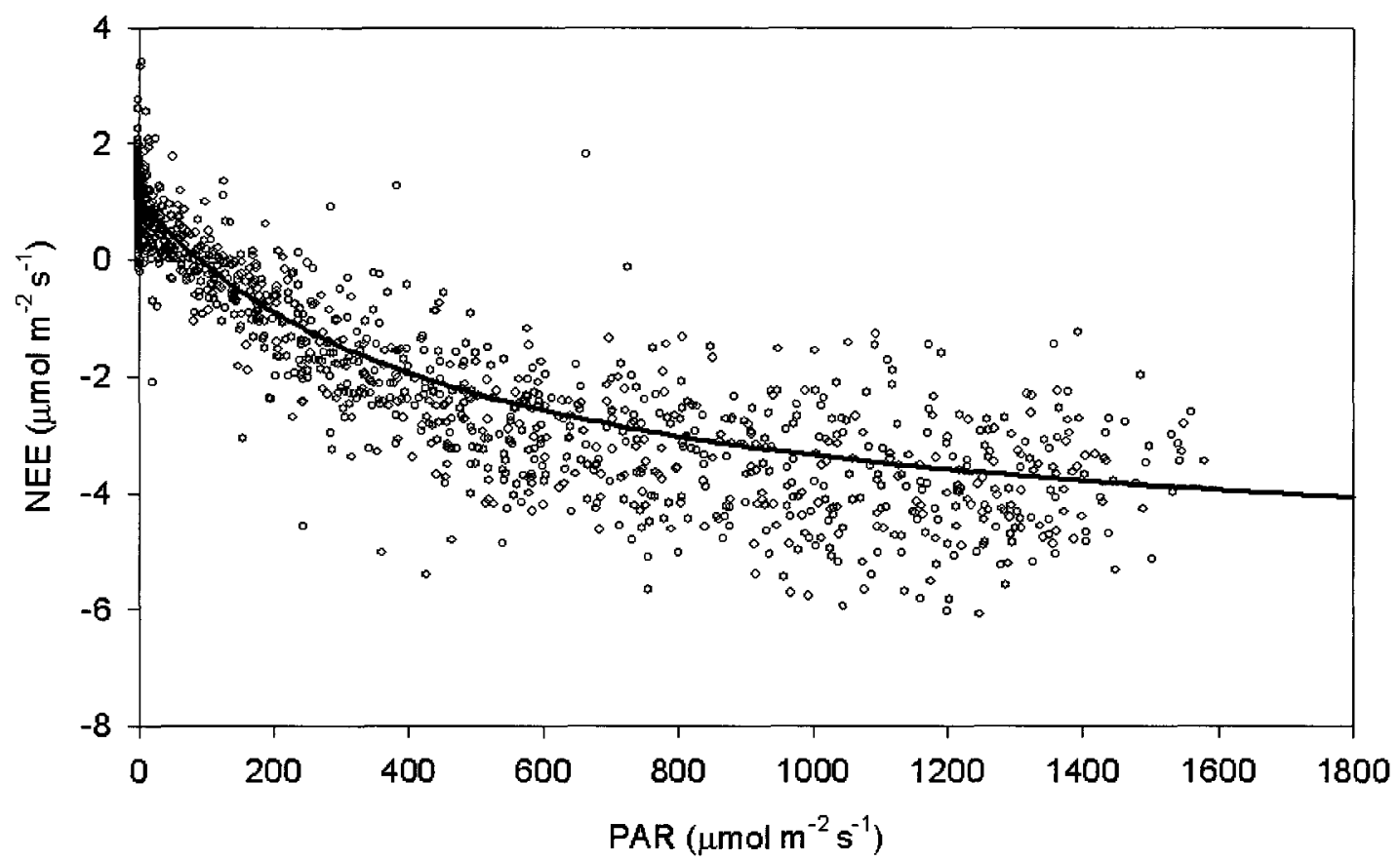

Figure 24. The relationship between net ecosystem exchange of $\mathrm{CO}_{2}, \mathrm{NEE}$, and photosynthetically active radiation, PAR for the study period. Symbols correspond to 30 minute averages of NEE which were above the frictional velocity threshold of $0.1 \mathrm{~m} \mathrm{~s}^{-1}$ at night $\left(\mathrm{PAR}<20 \mu \mathrm{mol} \mathrm{m}^{-2} \mathrm{~s}^{-1}\right)$. The curved line corresponds to Equation 3 with parameters listed in Table 10. Negative values represent ecosystem uptake of carbon.

Table 10. Parameters for Equation 3 describing the response of NEE to PAR and average ecosystem air temperature for the study period. $\mathrm{GP}_{\max }$ is maximum gross photosynthesis, $\alpha$ is the initial slope of the curve, $R_{10}$ is ecosystem respiration at a reference temperature of $10^{\circ} \mathrm{C}, \mathrm{n}$ is the number of observations, $\mathrm{Q}_{10}$ is rate of increase in ER for a $10^{\circ} \mathrm{C}$ increase in temperature*, RMSE is the root mean square error, and Temp is the average a ir temperature for the study period. Values in brackets indicate approximate standard error.

\begin{tabular}{l|llllll}
\hline & $\begin{array}{l}G P_{\max } \\
\left(\mu \operatorname{mol} m^{-2}\right.\end{array}$ & $\alpha$ & $\begin{array}{l}\boldsymbol{R}_{10} \\
\left(\mu \operatorname{mol} m^{-2}\right.\end{array}$ & $n$ & $R M S E$ & Temp $\left({ }^{\circ} \mathrm{C}\right)$ \\
$\boldsymbol{s}^{-1)}$ & -7.12 & -0.01 & 0.89 & 1253 & 0.83 & 11.7 \\
\hline Sedge & $(0.16)$ & $(0.0007)$ & $(0.04)$ & & & \\
Fen & & & & & & \\
\hline
\end{tabular}

* The $\mathrm{Q}_{10}$ value was set to 2 , which is a common ly accepted value when assess ing net ecosystem exchange at the ecosystem level. 


\subsection{Spatial Variation in Ecosystem $\mathrm{CH}_{4}$ and $\mathrm{CO}_{2}$ Flux}

In addition to the influence of temporal variations in environmental factors such as turbulence, temperature, and light, variations in wind direction and footprint size influence the flux source area. For the spatial analysis of $\mathrm{CH}_{4}$ and $\mathrm{CO}_{2}$ flux, the area around the tower was divided into three distinct directional sectors based on landscape composition: sector $1,0^{\circ}-135^{\circ}$ (sedge fen dominated by lawn topography to NE, rocky upland area to SE); sector $2,135^{\circ}-225^{\circ}$ (sedge fen with tussock topography, small, open water bodies and rocky upland area); and sector $3,225^{\circ}-360^{\circ}$ (sedge fen and shrub peat mound areas) (Figure 2). While the area immediately around the tower was homogenous in all directions, all sectors became heterogeneous when the flux footprint included distances greater than 70 meters (Figure 2).

For all three sectors, high $u *$ resulted in large footprints and low $\mathrm{CH}_{4}$ flux (Figure 25) presumably due the influence of greater turbulence rather than different source areas. For example, there was no tendency for fluxes to differ among the three directional sectors when footprints exceeded $70 \mathrm{~m}$. At smaller footprint lengths and lower $\mathrm{u}_{*}, \mathrm{CH}_{4}$ fluxes tend to be slightly greater from sector 1 and slightly smaller from sector 2 , which may be the result of slightly lower average soil temperatures associated with the sector 2 measurements (sector $2: 9.8 \pm 0.3{ }^{\circ} \mathrm{C}$ vs. sector $1: 11.3 \pm 0.3{ }^{\circ} \mathrm{C}$ ) during the sampling period $\left(\mathrm{F}_{1,132}=11.32, \mathrm{p}=0.001\right)$

NEE also demonstrated similar trends and magnitudes when winds came from sectors 2 and 3 , while sector 1 was significantly different, until a critical footprint distance of approximately 70 meters was reached (Figure $26 \&$ Table 11). Significantly less $\mathrm{CO}_{2}$ uptake (negative NEE) may have occurred in sector 1 due to slight differences 
in spatial heterogeneity within the three sectors. Significantly greater $\mathrm{CO}_{2}$ uptake tended to occur within sector 3 at distances greater than $70 \mathrm{~m}$ (sedge fen and dwarf birch shrub peat mound area) when compared to the other two sectors (Table 11). These tower results agree with the greater rates of $\mathrm{CO}_{2}$ uptake measured using the chamber system in the shrub areas (Figure 16). 

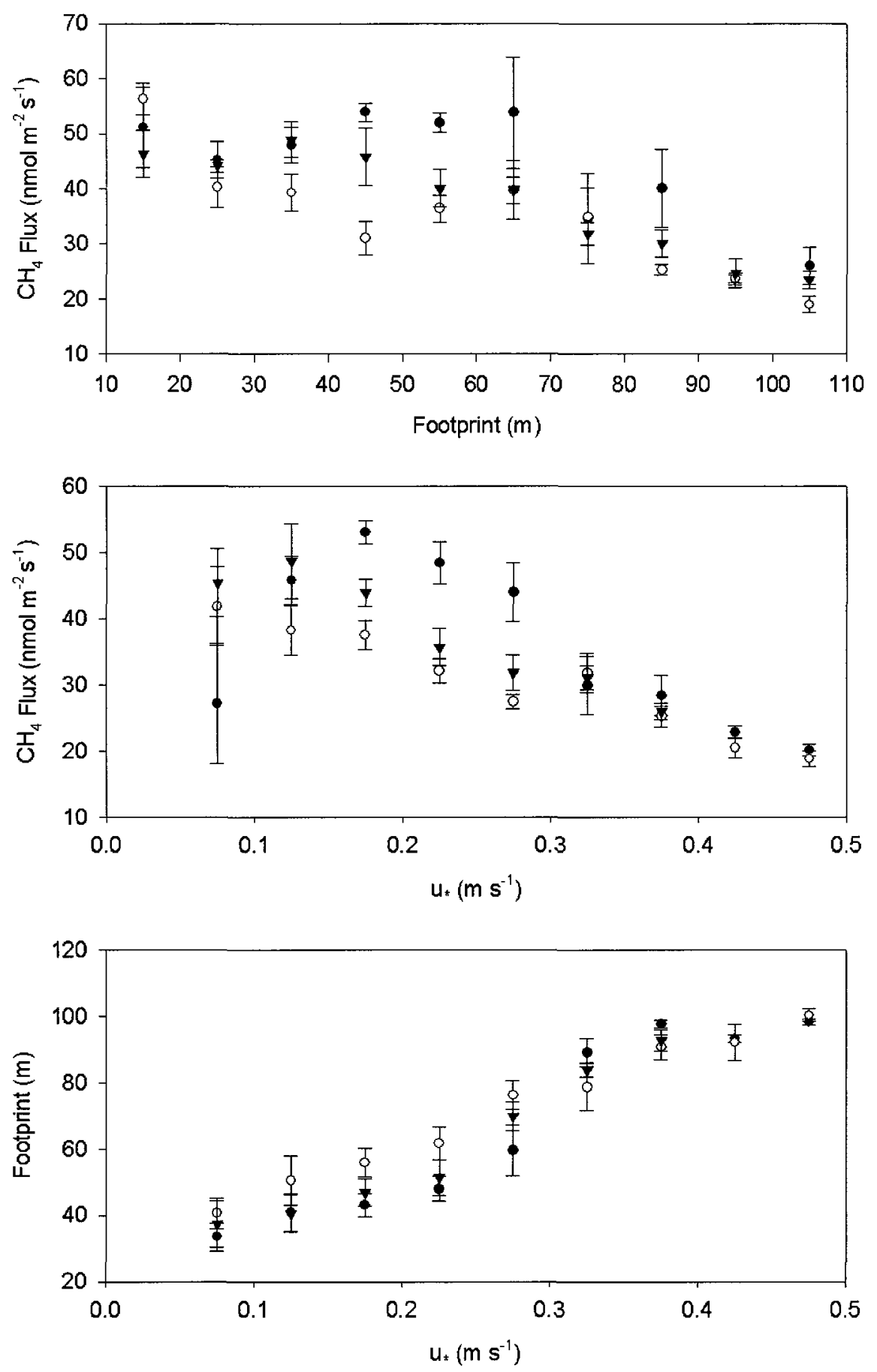

Figure 25. The relationship between 30 minute averages of $\mathrm{CH}_{4}$ flux, friction velocity, $\mathbf{u} *$, and footprint distance for three spatially different areas within the fetch of the eddy covariance tower. Closed circles represent sector $1\left(0^{\circ}-135^{\circ}\right)$, open circles represent sector $2\left(135^{\circ}-225^{\circ}\right)$, and closed triangles represent sector $3\left(225^{\circ}-360^{\circ}\right)$. Data are binned by footprint $\left(10 \mathrm{~m}\right.$ wide) and $\mathrm{u}_{*}\left(0.05 \mathrm{~m} \mathrm{~s}^{-1}\right.$ wide $)$. Error bars represent $\pm 1 \mathrm{SE}$. The number of samples for each symbol ranges from 6 to 36 . 


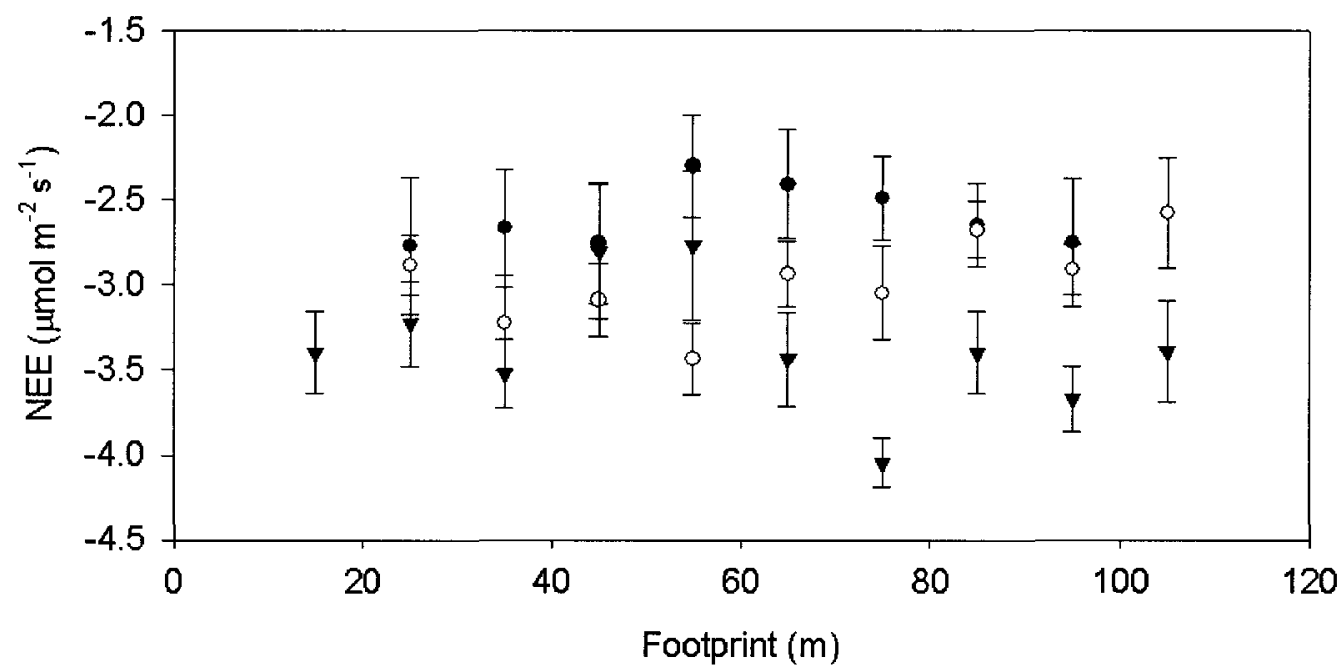

Figure 26. The relationship between net ecosystem exchange of $\mathrm{CO}_{2}, \mathrm{NEE}$, and footprint distance for three spatially different areas within the fetch of the eddy covariance tower. Closed circles represent sector $1\left(0^{\circ}-135^{\circ}\right)$, open circles represent sector $2\left(135^{\circ}-225^{\circ}\right)$, and closed triangles represent sector $3\left(225^{\circ}-360^{\circ}\right)$. Error bars represent $\pm 1 \mathrm{SE}$. The number of samples for each symbol ranges from 9 to 50 .

Table 11. Average daytime $(10 \mathrm{am}-6 \mathrm{pm})$ NEE for footprint distances from tower of 70 $\mathrm{m}$ or less and for distances greater than $70 \mathrm{~m}$ for the three sectors during the study period. Error associated with NEE is $\pm 1 \mathrm{SE}$. Numbers in brackets ind icate the number of observations. Different superscript letters indicate significant differences within a column $(\mathrm{p}<0.05)$. NEE, net ecosystem exchange of $\mathrm{CO}_{2}$.

\begin{tabular}{l|ll}
\hline & $\begin{array}{l}\text { Average NEE }<70 m \\
\left(\mu \mathrm{mol} \mathrm{m}^{-2} \mathrm{~s}^{-1}\right)\end{array}$ & $\begin{array}{l}\text { Average NEE }>70 m \\
\left(\mu \mathrm{mol} \mathrm{m}^{-2} \boldsymbol{s}^{-1}\right)\end{array}$ \\
\hline Sector 1 & $-2.55 \pm 0.16(86)^{\mathrm{a}}$ & $-2.58 \pm 0.15(83)^{\mathrm{a}}$ \\
Sector 2 & $-3.13 \pm 0.11(74)^{\mathrm{b}}$ & $-2.84 \pm 0.10(97)^{\mathrm{a}}$ \\
Sector 3 & $-3.25 \pm 0.12(73)^{\mathrm{b}}$ & $-3.62 \pm 0.11(130)^{\mathrm{b}}$ \\
\hline
\end{tabular}




\subsection{Growing Season C B udget and GWP}

Daily total and cumulative NEE was computed for the full growing season (June 1 to August 31) after gap-filling as described in section 3.6.6 (Figure 27). The fen was a sink for $\mathrm{CO}_{2}$ with overall estimated NEE for the 2009 growing season to be $-66.3 \mathrm{~g} \mathrm{C} \mathrm{m}^{-}$ 2.

Growing season $\mathrm{CH}_{4}$ exchange was determined by first computing daily average $\mathrm{CH}_{4}$ fluxes using days where data coverage was $>25 \%$ (12 half-hour measurements) $\left(\mathrm{n}=27\right.$ days). Next, daily averages of $\mathrm{CH}_{4}$ flux, $5 \mathrm{~cm}$ soil temperature, and $\mathrm{u} *$ were calculated in order to minimize variance associated with rapid changes in wind speed, direction, and footprint size. Modelled daily $\mathrm{CH}_{4}$ flux was obtained from equation 5 with parameters listed in Table 12. A good agreement $\left(r^{2}=0.69\right)$ between measured and modeled data was obtained (Figure 28). The overall estimated $\mathrm{CH}_{4}$ emission for the 2009 growing season was $2390 \mathrm{mg} \mathrm{C} \mathrm{m}^{-2}$ or $2.4 \mathrm{~g} \mathrm{C} \mathrm{m}^{-2}$ (Figure 29). The amount of $\mathrm{C}$ released as $\mathrm{CH}_{4}$ was approximately $3.75 \%$ of that sequestered through ecosystem exchange of $\mathrm{CO}_{2}$.

The average amount of DOC $\left(\mathrm{mg} \mathrm{l}^{-1}\right)$ for the three sampling periods is listed in Table 13, along with the average slope and flow rates for the inlet and outlet. Average flux values for these three days were calculated using equation 4 with an estimated peat hydraulic conductivity of $10^{-4} \mathrm{~m} \mathrm{~s}^{-1}$, a fen area of 42 hectares, and a varying hydraulic head (Table 14). The average of these three days was used to calculate the overall estimated DOC flux for the 2009 growing season. The estimated DOC flux was $0.9 \mathrm{gC}$ $\mathrm{m}^{-2}$. The amount of $\mathrm{C}$ released as DOC was approximately $1.33 \%$ of that sequestered through NEE. 
Overall, the fen was a sink of approximately $63.0 \mathrm{~g} \mathrm{C} \mathrm{m}^{-2}$ during the growing season of 2009 at Daring Lake. Emission of $\mathrm{CH}_{4}$ and loss of DOC accounted for approximately $5 \%$ of the overall growing season $\mathrm{C}$ taken up as $\mathrm{CO}_{2}$ (Table 15$)$. With these relatively small $\mathrm{CH}_{4}$ emissions and large $\mathrm{CO}_{2}$ uptake, the growing season $\mathrm{C}$ budget for the fen represented a negative forcing effect on atmospheric warming over both the 20 year and 100 year timescales (Table 15). 

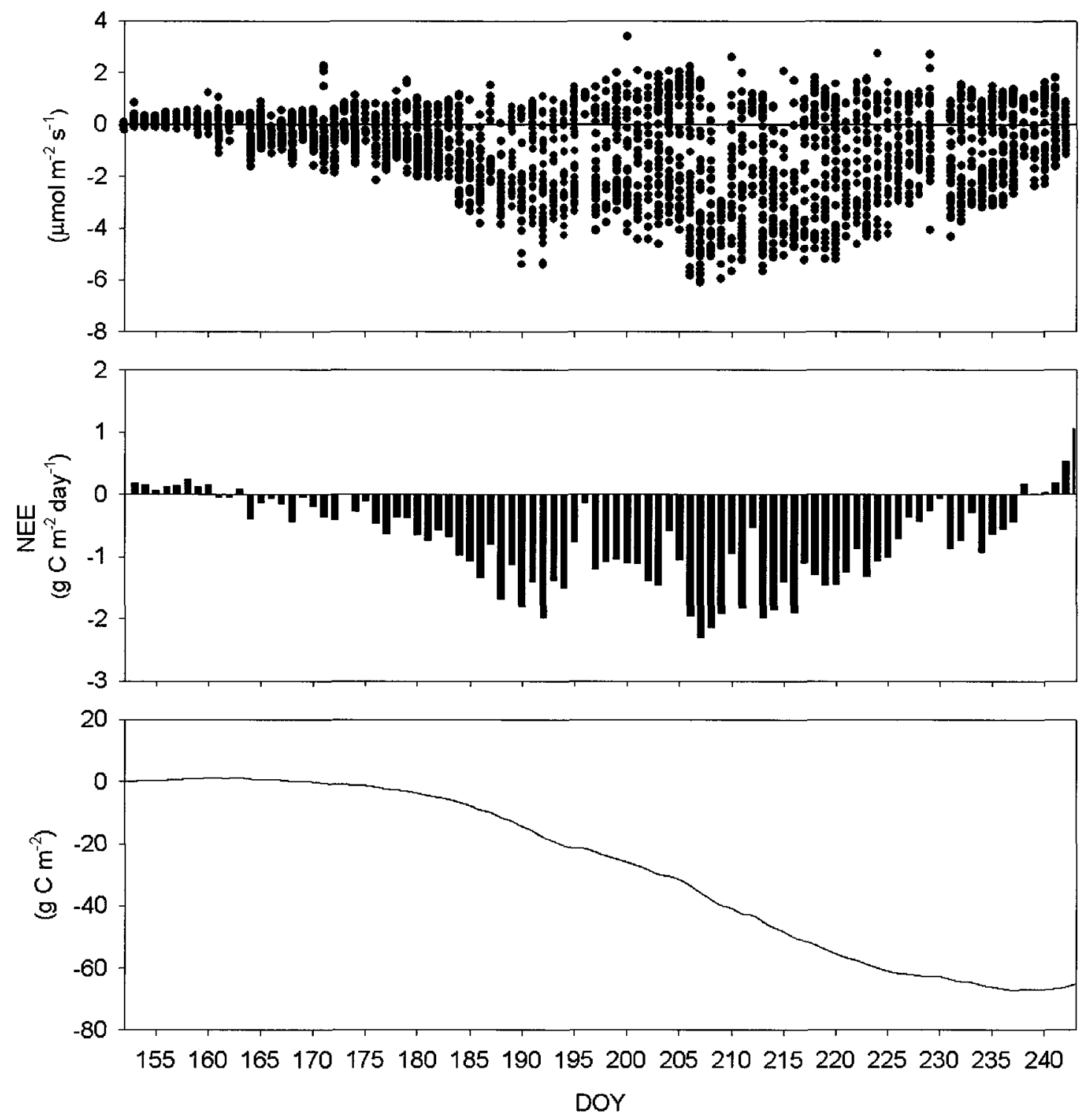

Figure 27. Half-hour measured net ecosystem exchange (NEE) (top), gap-filled daily NEE (middle) and cumulative NEE (bottom) for 1 June to 31 August 2009. Positive values represent a net $C$ loss to the atmosphere while negative values represent a net $C$ accumulation by the ecosystem. 
Table 12. $\mathrm{CH}_{4}$ input and model parameters for the growing season of 2009 using Equation $5 . T_{\text {ref, }}$, average temperature for the sampling period, $u *_{\text {ref }}$, average frictional velocity for the sampling period, a, b, c are fit parameters, RMSE, root-mean standard error, $\mathrm{r}^{2}$, correlation coefficient, $\mathrm{n}$, number of samples. Errors associated with fit parameters are \pm SE. The number of daily averages used was 27 .

\begin{tabular}{l|c}
\hline Parameters & \\
\hline $\left.\mathrm{T}_{\text {ref }}{ }^{\circ} \mathrm{C}\right)$ & 8.57 \\
$\mathrm{u} *$ ref $\left(\mathrm{m} \mathrm{s}^{-1}\right)$ & 0.23 \\
$\mathrm{a}\left(\mathrm{mg} \mathrm{m}^{-2} \mathrm{day}^{-1}\right)$ & $25.2 \pm 1.31$ \\
$\mathrm{~b}\left({ }^{\circ} \mathrm{C}\right)$ & $2.07 \pm 0.51$ \\
$\mathrm{c}\left(\mathrm{m} \mathrm{s}^{-1}\right)$ & $0.17 \pm 0.09$ \\
$\mathrm{RMSE}$ & 5.0 \\
$\mathrm{r}^{2}$ & 0.69 \\
\hline
\end{tabular}

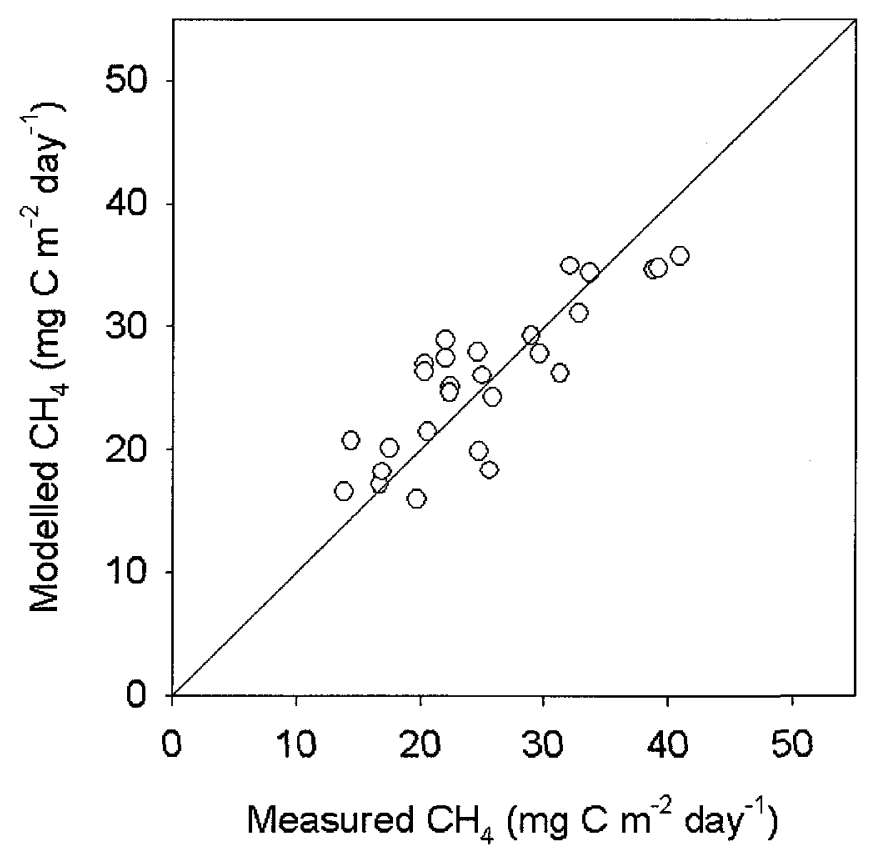

Figure 28. Daily integrated mean values of eddy covariance $\mathrm{CH}_{4}$ emission versus modelled emission rates from Equation 5 and modelled parameters from Table 12. $\mathrm{CH}_{4}$, methane. 

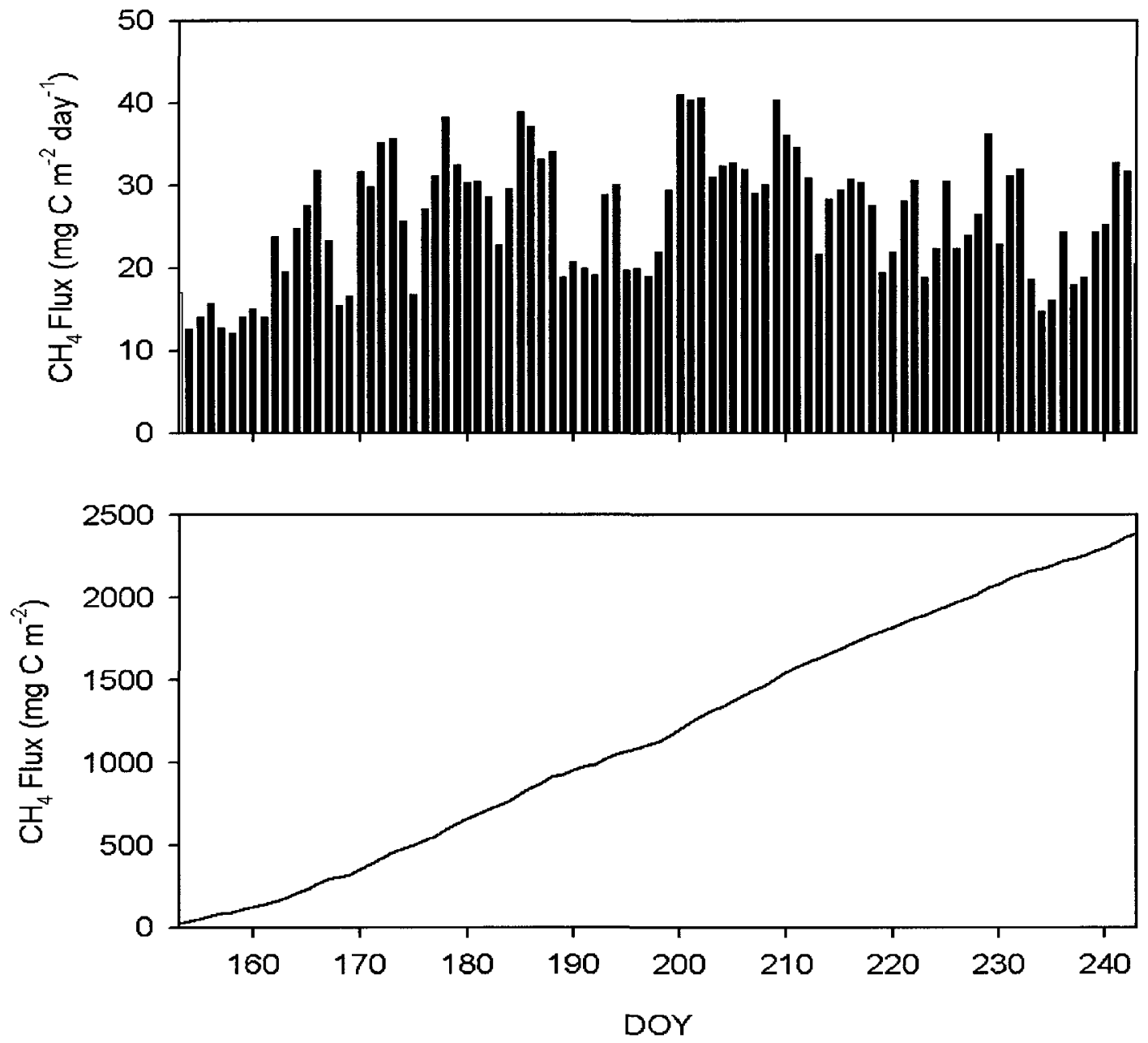

Figure 29. Daily $\mathrm{CH}_{4}$ flux (middle) and cumulative $\mathrm{CH}_{4}$ flux (bottom), modelled, for 1 June to 31 August 2009. Positive values result in net $\mathrm{C}$ loss to atmosphere. $\mathrm{CH}_{4}$, methane. 
Table 13. Average dissolved organic carbon (DOC), slope ( $d h / d z)$, and flow rates for three measurement periods during summer of 2009, Daring Lake. Values within brackets indicate standard error of the mean. The number of samples for each measurement is 3 .

\begin{tabular}{l|lll}
\hline & DOY 203 & DOY 213 & DOY 223 \\
\hline $\begin{array}{l}\text { Inlet Concentration } \\
\left(\mathrm{mg} \mathrm{C} \mathrm{I}^{-1}\right)\end{array}$ & $52.35(4.09)$ & $48.93(3.93)$ & $42.35(5.51)$ \\
Inlet slope $(d h / d z)$ & 0.0015 & & \\
Inlet flow $\left(\mathrm{cm}^{3} \mathrm{~s}^{-1}\right)$ & 0.96 & 0.0006 & 0.0002 \\
Outlet Concentration & $27.00(2.04)$ & 0.90 & 0.82 \\
$\left(\mathrm{mg} \mathrm{C} \mathrm{I}^{-1}\right)$ & & $27.53(2.73)$ & $24.96(3.77)$ \\
Outlet slope $(d h / d z)$ & 0.028 & & \\
Outlet flow $\left(\mathrm{cm}^{3} \mathrm{~s}^{-1}\right)$ & 3.46 & 0.029 & 0.027 \\
\hline
\end{tabular}

Table 14. Average ecosystem storage change of dissolved organic carbon, DOC, for three measurement periods during the summer of 2009, Daring Lake. Values within brackets indicate standard error of the mean. Positive values indicate loss of DOC from the ecosystem. The number of samples for each measurement is 6 .

\begin{tabular}{|c|c|c|c|c|}
\hline & $D O Y 203$ & DOY 213 & $D O Y 223$ & $\begin{array}{l}\text { Average } \\
\text { Daily Rate }\end{array}$ \\
\hline $\begin{array}{l}\text { Ecosystem Storage Change } \\
\text { DOC }\left(\mathrm{g} \mathrm{C} \mathrm{m}^{-2} \text { day }^{-1}\right)\end{array}$ & $8.88 \times 10^{-3}$ & $1.08 \times 10^{-2}$ & $8.74 \times 10^{-3}$ & $\begin{array}{l}9.47 \times 10^{-3} \\
(0.0028)\end{array}$ \\
\hline
\end{tabular}

Table 15. GWP and modelled carbon balance for the growing season (June 1 - August 31) 2009 at Daring lake, NT. Positive numbers indicate ecosystem carbon loss and ne gative numbers indicate ecosystem carbon uptake and negative forcing potential to warm atmosphere.

\begin{tabular}{l|llll}
\hline & Fen $\mathrm{CO}_{2}$ & Fen $\mathrm{CH}_{4}$ & Fen DOC & Fen Total \\
\hline $\begin{array}{l}\text { Carbon Balance } \\
\left.(\mathrm{g} \mathrm{C} \mathrm{m})^{-2}\right)\end{array}$ & -66.3 & 2.4 & 0.9 & -63.0 \\
$\begin{array}{l}\text { GWP }(20 \text { yr horizon }) \\
\left(\mathrm{g} \mathrm{CO}_{2} \mathrm{~m}^{-2}\right)\end{array}$ & -243.3 & 229.4 & & -13.8 \\
$\begin{array}{l}\mathrm{GWP}(100 \text { yr horizon) } \\
\left(\mathrm{g} \mathrm{CO}_{2} \mathrm{~m}^{-2}\right)\end{array}$ & -243.3 & 66.9 & & -176.3 \\
\hline
\end{tabular}




\subsection{DISCUSSION}

This research builds on the considerable body of literature on land-atmosphere interactions in arctic wetlands and in particular, sedge fen tundra. For the first time, to my knowledge, concurrent ecosystem scale fluxes of $\mathrm{CO}_{2}$ and $\mathrm{CH}_{4}$ are reported for this type of arctic ecosystem. These results highlight how factors such as vegetation, moisture, temperature and light influence these components of the $\mathrm{C}$ budget and in particular, how the importance of these factors change as fluxes are integrated over larger spatial scales.

\section{1 $\quad \mathrm{CO}_{2}$ Fluxes}

On an ecosystem level, PAR and temperature were found to be important factors controlling daily and $30 \mathrm{~min}$ variations in NEE as these factors influence rates of photosynthesis and respiration. Photosynthesis is primarily controlled by the amount of incoming solar radiation and to a lesser extent temperature (Vourlitis et al., 2000). As PAR increases, photosynthetic activity increases to a saturation point where an increase in PAR no longer promotes the plant's ability to photosynthesize at an optimum rate. After this point, temperature often becomes an important factor influencing the magnitude of 30 min NEE (Vourlitis and Oechel, 1999; Kwon et al., 2006) and may explain the increase in scatter in NEE around the temperature-light response curve as PAR increases (Figure 24). When temperatures increase, ER, which is a function of autotrophic and heterotrophic respiration, may respond through increased microbial activity and plant respiration resulting in an exponential rise in $\mathrm{CO}_{2}$ release (Vourlitis and Oechel, 1999; Kwon et al., 2006). The temperature-light response curve in this study was associated with a coefficient of determination of 0.76 , indicating that only $24 \%$ of 
the variation in NEE could not be explained by variations in PAR and temperature. This was similar to the relationship developed for a sedge fen landscape with very similar site characteristics at Happy Valley, Alaska $\left(\mathrm{r}^{2}=0.70-0.75\right)$ (Vourlitis et al., 2000). In contrast, the $r^{2}$ values for upland tundra at Daring Lake (Lafleur and Humphreys, 2008) were less $\left(r^{2}=0.56-0.66\right)$ in 2004 to 2006 . The greater proportion of variation in NEE explained by PAR and temperature in the sedge fen ecosystems compared to the upland tundra may be due to differences in species composition but also due to the relatively consistent moisture conditions of these sedge fen ecosystems. Upland tundra NEE may respond more dramatically to rainfall events for example.

In this study, daily $\mathrm{CO}_{2}$ uptake increased more with sunnier conditions when it was warmer but other studies suggest that temperature change may have a minimal effect on $\mathrm{CO}_{2}$ uptake, as arctic plants have a broad range at which optimum photosynthesis can occur (Vourlitis and Oechel, 1999; Vourlitis et al., 2000).

Although many studies show the importance of seasonal variations in soil moisture or water table on $\mathrm{CO}_{2}$ exchange (Vourlitis and Oechel, 1999; Vourlitis et al., 2000; Corradi et al., 2005; Kwon et al., 2006; Merbold et al., 2009), there was no evidence of these factors playing a role in temporal variations in ecosystem $\mathrm{CO}_{2}$ exchange. The lack of a wetness control may be due to minimal water table drawdown from the beginning ( $5 \mathrm{~cm}$ below surface) to the end $(13 \mathrm{~cm}$ below surface) of the study period, resulting in a hydraulic head difference of only $8 \mathrm{~cm}$, while in these other studies, maximum variation was larger (e.g. $20 \mathrm{~cm}$ in the study by Vourlitis and Oechel(1999)). 
In contrast, at the small plot scale, chamber measurements of $\mathrm{CO}_{2}$ exchange highlighted the importance of vegetation characteristics and soil moisture as well as light and temperature on both spatial and temporal variations in $\mathrm{CO}_{2}$ changes.

Overall, GEP, ER, and NEE did not differ between lawns and tussocks for the study period. While there were significant differences in soil temperature and VWC between the two communities, total LAI and \% cover did not differ. Instead, spatial variations in NEE and GEP on a per collar basis were significantly related to LAI and \% cover while ER related to GEP illustrating that the simple designation of tussock vs. lawn could not explain the considerable spatial variability in $\mathrm{CO}_{2}$ exchange at this site. Other wetland studies have found differences in C fluxes that could be related to both micro topography and vegetation characteristics. Riutta et al. (2007) suggested that GEP differences within 5 similar communities containing both lawns and tussocks in a northern boreal fen were determined in part by significant differences in \% vascular cover and also by differences in water table depth where a lower water table resulted in increased ER. However, Riutta et al. (2007) also noted a strong relationship between GEP and vascular respiration, supporting the conclusion that a portion of ER is driven by changes in GEP. Sullivan et al. (2008) suggested that higher GEP in tussocks vs. lawns in a high arctic fen was directly related to greater LAI and plant biomass. Christensen et al. (2000) reported higher net $\mathrm{CO}_{2}$ uptake (more negative NEE) in tussocks compared to lawns which is in contrast to the observations by Heikkinen et al. (2002) in a low arctic wet tundra landscape and Strack et al. (2006) within a wet fen northern ecosystem where lawns had greater net $\mathrm{CO}_{2}$ uptake. 
Temporal variations in plot scale measurements of GEP, ER, and NEE were directly related to temporal variations in PAR, air temperature, soil temperature, water table depth, and VWC. It is interesting to note that ER within lawn and tussocks at Daring Lake had opposite significant relationships to VWC, but increases in ER in both microsites related to increases in soil temperature. This may have occurred because lawns were already moist enough for optimal ER and additional water may have reduced rates of aerobic respiration while tussocks required more mo isture for optimal ER. Other field and laboratory studies have proposed a relationship between soil respiration and VWC with greatest $\mathrm{CO}_{2}$ effluxes occurring at some optimum moderate $\mathrm{VWC}$ and decreasing respiration at higher or lower VWC (Bunnell et al., 1997, Reth et al., 2005, Strack and Price, 2009). However, the nature of this relationship is difficult to isolate due to concurrent variations in other variables such as soil temperature, substrate amount, $\mathrm{pH}$ value, and nutrient status (Reth et al., 2005). Increases in temperature most likely increased plant and soil respiration as the water table and VWC decreased throughout the study. Sullivan et al. (2008) also showed that soil drying increased ER in saturated lawn micro topography. However, as water table increased, ER in hummocks decreased but as VWC was not reported by Sullivan et al. (2008), it is difficult to suggest the reasons for this discrepancy. In a WT and temperature manipulation experiment in an Alaskan sedge fen tundra ecosystem, increases in soil temperature and decreases in water table were related to increases in ER (Oechel et al., 1998). Vourlitis et al. (2000) suggested that variations in WT, independent of temperature, may act as the dominant factor that may cause these ecosystems to switch from being a $\mathrm{C}$ sink to being source of $\mathrm{C}$. 


\section{$5.2 \quad \mathrm{CH}_{4}$ Fluxes}

In contrast to $\mathrm{CO}_{2}$ exchange, $\mathrm{CH}_{4}$ emissions were significantly different between lawns and tussocks. The spatial as well as temporal variations in these fluxes were also related to many of the same abiotic controls important in $\mathrm{CO}_{2}$ exchange. Overall, the significantly cooler, wetter, lawns resulted in significantly higher $\mathrm{CH}_{4}$ flux (almost twice) compared to the elevated, warm, dry tussocks. As total $\mathrm{CH}_{4}$ emissions depend in part on production in anaerobic soil conditions and consumption in aerobic soil conditions, it is not surprising that greater rates of $\mathrm{CH}_{4}$ emission are common in microsites with greater VWC. For example, $\mathrm{CH}_{4}$ emissions were greatest within saturated lawn microtopography in a hummocky fen in the high Arctic (Christensen et al., 2000). Christensen et al. (1995) found greater rates of $\mathrm{CH}_{4}$ emission in wet tussock habitats vs. mesic habitats in Siberian and European tundra environments.

The factors influencing $\mathrm{CH}_{4}$ transport are just as important as production and oxidation in overall emission (Lai, 2009). The presence of vascular vegetation with aerenchymatous tissue, such as sedges, which can develop deep rooting systems into the anaerobic zone, provides a conduit for $\mathrm{CH}_{4}$ to the surface (Grondahl et al., 2008; Lai, 2009). Vegetation characteristics have been shown to influence spatial differences in $\mathrm{CH}_{4}$ flux at a number of arctic sites (Christensen et al., 1995; Christensen et al., 2000;

Grondahl et al., 2008; Hayne, 2009). Methane emission has also been linked to ecosystem productivity at waterlogged sites where sedge root exudates and fresh plant material available for decomposition supply the necessary substrate for methanogenesis to occur (Bellisario et al., 1999; Christensen et al., 2000). In this study, $\mathrm{CH}_{4}$ flux was positively related to sedge LAI when the tussock and lawn collars were combined into a 
single group, indicating the potential for $\mathrm{CH}_{4}$ emission to be influenced by these plants. However, since there was no relationship between $\mathrm{CH}_{4}$ emission and ecosystem productivity in this study, this suggests that sedges may have had a greater influence on transport than production.

Spatial differences in temperature can affect the rate at which methanogenes is occurs; however, it is tightly related to soil moisture (Lai, 2009). Generally, a positive relationship exists between temperature and microbial production of $\mathrm{CH}_{4}$; however, oxidation rates of $\mathrm{CH}_{4}$ may influence $\mathrm{CH}_{4}$ emission when the water table is below the surface (Treat et al., 2007). Christensen (2000) found in five distinct Arctic tundra environments that within-season variability of $\mathrm{CH}_{4}$ flux at wet sites were primarily controlled by soil temperature; however, at sites that were generally dry, $\mathrm{CH}_{4}$ flux was primarily controlled by position of water table.

In general, temporal variations in $\mathrm{CH}_{4}$ emissions were positively related to temperature, VWC, and WT; however, these relationships were not always consistent between tussocks and lawns. While tussocks had a positive relationship with VWC, lawns did not. Due to the small drop in WT over the study period, VWC remained relatively high and constant in lawns, while tussocks experienced more variation in moisture. As a result, the depth of the aerobic zone was much more variable in tussocks and may have led to more variable rates $\mathrm{fCH}_{4}$ oxidation, potentially resulting in variable rates of $\mathrm{CH}_{4}$ emissions. $\mathrm{CH}_{4}$ emission was greater when the $\mathrm{WT}$ was closer to the surface which is in accordance with typical relationships observed in field studies (Christensen et al., 2000). Bellisario et al. (1999) observed a similar relationship between $\mathrm{CH}_{4}$ and WT in a boreal peatland where the range of WT $(15 \mathrm{~cm})$ among sites 
was very similar to this study. For permanently, or close to permanently, waterlogged zones, plant productivity has been suggested to be the main control of $\mathrm{CH}_{4}$ emission as plants provide substrate for methanogenesis and ventilation associated with plant $\mathrm{CH}_{4}$ transport (Whiting and Chanton, 1993; Bellisario et al., 1999; Christensen et al., 2000). For drier sites, a positive relationship between plant productivity and $\mathrm{CH}_{4}$ emission is not necessarily valid as WT may override other biotic and abiotic controls (Bubier and Moore, 1994; Waddington et al., 1996; Christensen et al., 2000). At Daring Lake, GEP was not measured concurrently with $\mathrm{CH}_{4}$ emissions but when examining the average $\mathrm{CH}_{4}$ flux for each collar, there was no relationship with the average GEP. However, concurrent measurements of $\mathrm{CH}_{4}$ flux and $\mathrm{ER}_{\mathrm{S}}$ were positively correlated in time for tussocks and combined lawns and tussocks; however, no significant relationship was observed for $\mathrm{CH}_{4}$ and $\mathrm{ER}_{\mathrm{S}}$ in lawns. It is possible that this links autotrophic respiration and thus plant productivity to $\mathrm{CH}_{4}$ emissions, however, this is confounded by temporal variations in abiotic factors (temperature, VWC, WT, and PAR) that promote both $\mathrm{CO}_{2}$ and $\mathrm{CH}_{4}$ production.

While there have been many arctic studies examining $\mathrm{CO}_{2}$ exchange, ecosystem scale controls on $\mathrm{CH}_{4}$ flux dynamics in the Arctic remain uncertain (Sachs et al., 2008). Ecosystem scale $\mathrm{CH}_{4}$ flux studies have been conducted in a limited number of arctic and northern boreal ecosystems (Friborg et al., 2000; Hargreaves et al., 2001; Sachs et al., 2008; Wille et al., 2008; Gazovic et al., 2010; Long et al., 2010); however, most of these have taken place in either wet polygonal tundra or in treed fens.

At the Daring Lake fen, temperature and friction velocity controlled variation in daily and 30 min $\mathrm{CH}_{4}$ emissions. The positive relationship between temperature and $\mathrm{CH}_{4}$ 
emission reflects the direct dependence of microbial activity on temperature (Wille et al., 2008). This relationship has been well documented in numerous $\mathrm{CH}_{4}$ emission studies (Friborg et al., 2000; Hargreaves et al., 2001; Wille et al., 2003; Sachs et al., 2008; Long et al., 2010).

Water table position has been identified as another environmental variable controlling methane emission (Friborg et al., 2000) and was clearly the case for the small plot-scale $\mathrm{CH}_{4}$ fluxes at Daring Lake. This can be explained through regulation of methane production and consumption in the aerobic and anaerobic layers of the peat profile, with increasing consumption resulting in decreasing $\mathrm{CH}_{4}$ emission as the aerobic/anaerobic ratio increases (Wille et al., 2008). However, in contrast to the chamber measurement results, variations in water table did not relate to daily variation in ecosystem scale $\mathrm{CH}_{4}$ emissions. This is similar to other studies where water table remained at or just below peat surface (Hargreaves et al., 2001; Wille et al., 2008). This is also seen at sites where the water table was significantly below the peat surface ( 40 $60 \mathrm{~cm}$ ) throughout the study period (Long et al., 2010). A relationship between ecosystem scale $\mathrm{CH}_{4}$ fluxes and water table was observed at a high-arctic fen in Greenland where water table varied from above the fen surface to $80 \mathrm{~cm}$ below the surface during the study period (Friborg et al., 2000). The water table at the beginning of our measurement period was located below the peat surface $(5 \mathrm{~cm})$. If measurements had been made when the water table was above the surface in the early spring, it is plausible that a relationship between $\mathrm{CH}_{4}$ and WT may have existed, however, the tendency for temperature to increase while water table drops through the growing season may confound such a relationship. 
Thaw depth has been identified as another abiotic factor controlling methane emission (Friborg et al., 2000). In our study, thaw depth was not a determinant of $\mathrm{CH}_{4}$ emission indicating that, while increases in temperature did increase available $\mathrm{C}$ at depth, dominant methane production is likely to have originated from the upper portion of the soil horizon. It is likely that the decreasing amount of biologically a vailable $\mathrm{C}$ substrate at depth used for energy production via methanogenesis was the controlling variable limiting production of $\mathrm{CH}_{4}$ in this area for microorganisms well adapted to cold environments (Wille et al., 2008). Several studies from Siberian arctic tundra report no relationship between thaw depth and $\mathrm{CH}_{4}$ emission (Sachs et al., 2008; Wille et al., 2008).

Atmospheric pressure drop resulting in bubble ebullition has also been identified as a factor controlling methane emission (Kellner et al., 2005, Tokida et al., 2007); however, in our study, there was no observed relationship. Kellner et al. (2005) indicate that a drop in pressure may cause episodic release of $\mathrm{CH}_{4}$ gas that was entrapped in peat cavities and stuck to pore walls, though adhesion, where over time they accumulate and grow. A pressure drop would cause an enlargement of the volume of gas, potentially resulting in release; however, Tokida et al. (2007) report that due to the episodic behavior of ebullitive $\mathrm{CH}_{4}$ flux, it is difficult to quantify.

In addition to temperature, turbulence in the near-surface boundary layer, quantified by $\mathrm{u}_{*}$, was a second important driver of $\mathrm{CH}_{4}$ flux at our site. $\mathrm{CH}_{4}$ fluxes increased with $\mathrm{u} *$ until approximately $0.1 \mathrm{~m} \mathrm{~s}^{-1}$ and then decreased when $\mathrm{u} *$ increased beyond $0.24 \mathrm{~m} \mathrm{~s}^{-1}$. To date, no other studies have reported exactly this relationship. The increase in $\mathrm{CH}_{4}$ emissions with increasing $\mathrm{u} *$ is consistent with observations by Fan et al. 
(1992) who reported similar results from a mixed tundra landscape with high surface coverage of water within the fetch. Hargreaves et al. (2001) described similar findings between momentum flux and $\mathrm{CH}_{4}$ emissions for periods up to one day within a $\mathrm{F}$ innish Lapland tundra site with 70 percent open standing water. Sachs et al. (2008) and Wille et al. (2008) also reported that $\mathrm{u} *$ was an important driver of $\mathrm{CH}_{4}$ flux for Siberian arctic polygonal tundra and both of these studies also reported the presence of open water bodies. A positive relationship between $\mathrm{CH}_{4}$ emission and $\mathrm{u} *$ for sites with open water is driven through changes in the near surface turbulent layer by diffusive and turbulent transfer across the water-air interface, with results from lake studies suggesting direct dependence of gas transfer on wind speed (Wille et al., 2008). Also, bubbles of $\mathrm{CH}_{4}$ that adhere to plant surfaces under the water may be released by agitation of plants, wave action, and under-water turbulence caused by increases in wind velocity (Sachs et al., 2008). In a northern Canadian moderately treed fen with a WT greater than $40 \mathrm{~cm}$ below the surface, Long et al. (2010) also found $\mathrm{CH}_{4}$ emissions to increase with $\mathrm{u}_{*}$. Increases in $\mathrm{CH}_{4}$ emission associated with increases in $\mathrm{u}_{*}$ in non-inundated surfaces, dominated by thick moss layers, may be a result of a thinning laminar boundary layer causing a high concentration grad ient between the soil and the turbulent boundary layer, ultimately resulting in an increase in diffusive flux of $\mathrm{CH}_{4}$ to the surface (Sachs et al., 2008). Hargreaves et al. (2001) found increases in $\mathrm{CH}_{4}$ emissions following calm periods (Sachs et al., 2008). However, it is suggested that storage flushing may only play a role on shorter timescales, and over longer time scales, the rate of $\mathrm{CH}_{4}$ emission may decrease.

Our results show a negative relationship between $\mathrm{CH}_{4}$ emission and $\mathrm{u} *$ greater than $0.24 \mathrm{~m} \mathrm{~s}^{-1}$, which is contrary to observations by Long et al. (2010) in a non- 
inundated ecosystem. At Daring Lake, sustained high $u *$ was associated with consistently low $\mathrm{CH}_{4}$ fluxes while calmer conditions (but still with $\mathrm{u} *$ above $0.1 \mathrm{~m} \mathrm{~s}^{-1}$ ) resulted in higher but much more variable $\mathrm{CH}_{4}$ fluxes as variations in temperature only influenced $\mathrm{CH}_{4}$ emissions when $\mathrm{u} *$ remained below $0.24 \mathrm{~m} \mathrm{~s}^{-1}$. Although $\mathrm{u} *$ was related to footprint size, there was no clear relationship between source area and $\mathrm{CH}_{4}$ emissions. One possibility is that under sustained turbulence, diffusion/ebullition rates match production rates, while under calmer conditions, particularly when $\mathrm{u}_{*}<0.1 \mathrm{~m} \mathrm{~s}^{-1}, \mathrm{CH}_{4}$ has the potential to accumulate within the peat (more so during warmer conditions) establishing a greater below to above ground concentration gradient such that when $\mathrm{u} *$ increases slightly, greater diffusion, ebullition and plant mediated transport is possible. This reasoning is supported by Sachs et al. (2008) who suggest that atmospheric parameters exhibit superior control over $\mathrm{CH}_{4}$ release when compared to temperature related production and emission and that the production and emission of $\mathrm{CH}_{4}$ are not closely linked on short timescales. Sachs et al. (2008) observed with congruent $\mathrm{CH}_{4}$ chamber and eddy covariance measurements that a slight disturbance of sediments beneath a floating chamber resulted in a quick five-fold $\mathrm{CH}_{4}$ concentration increase. This observation would imply that a substantial amount of free-phase $\mathrm{CH}_{4}$ is stored within the soil profile and that rates of $\mathrm{CH}_{4}$ production, transport, and emission proceed at varying rates dependent upon do minant biotic and abiotic controls.

A number of studies have compared chamber and eddy covariance flux magnitudes of either $\mathrm{CH}_{4}$ or $\mathrm{CO}_{2}$ within the same ecosystem(Griffis et al., 2000; Twine et al., 2000; Aurela et al., 2007; Rinne et al., 2007; Fox et al., 2008; Sachs et al., 2008). Both sampling techniques have potential uncertainties associated with them (Fox et al., 
2008; Grondahl et al., 2008; Sachs et al., 2008; Schrier-Uijl et al., 2010). Chamber measurement techniques have the potential to alter air pressure and air and soil temperature during sampling within the chamber (Kutzbach et al., 2007; Sachs et al., 2008), while the effects of atmospheric turbulence on $\mathrm{CH}_{4}$ release and production are inhibited (Sachs et al., 2008). Eddy covariance fluxes may be affected by heterogeneous soil characteristics and surface cover, turbulence properties, flow distortion, sensor separation, and instrument error (Schrier-Uijlet al., 2010). A lack of energy balance closure, which is not uncommon (Corradi et al., 2005), may result in underestimation of actual fluxes (Twine et al., 2000). While chambers are excellent over short timescales in small, well defined microtopography, measurements can have great spatial variability within similar vegetated areas resulting from vegetation patchiness and differences in soil composition, temperature, and moisture (Grondahl et al., 2008). Eddy covariance measurements may also incorporate other microtopographic areas not sampled using chamber analysis. As such, a good representative sample of all heterogeneous areas when attempting to quantitatively 'match' chamber and eddy covariance fluxes is necessary (Schrier-Uijl et al., 2010).

Results from Daring Lake show that average daily $(10 \mathrm{am}-6 \mathrm{pm})$ ecosystem-scale NEE was more negative (greater uptake of $\mathrm{CO}_{2}$ ) than average chamber $\mathrm{NEE}$, while average daily $\mathrm{CH}_{4}$ emission at the ecosystem-scale was lower (less release of $\mathrm{CH}_{4}$ ) than average chamber $\mathrm{CH}_{4}$ emission. Aurela et al. (2007) found in a boreal sedge fen that $\mathrm{CO}_{2}$ fluxes from both chamber and eddy covariance methods had similar magnitudes, while chamber $\mathrm{CO}_{2}$ flux was slightly lower (less uptake) on average than eddy covariance measurements. Griffis et al. (2000) in a sub-arctic sedge fen found that 
chambers had the potential to considerably underestimate $\mathrm{CO}_{2}$ fluxes. In addition, Twine et al. (2000) found that grassland eddy covariance measurements may underestimate $\mathrm{CO}_{2}$ fluxes by $10-30 \%$, while Fox et al. (2008) reported that chamber NEE had the potential to be $60 \%$ more negative than eddy covariance measurements and could potentially overestimate $\mathrm{CO}_{2}$ uptake in heterogeneous arctic tundra. Schrier-Uijl et al. (2010) found a difference of $51 \%$ when average $\mathrm{CH}_{4}$ field emissions from chambers and eddy covariance were assessed. However, when representative landscape elements were taken into account, the difference between chamber and eddy covariance $\mathrm{CH}_{4}$ flux became less $(13 \%)$.

\subsection{Carbon Exchange Rates at the Daring Lake Fen and other Arctic Sites}

The growing season pattern of $\mathrm{CO}_{2}$ flux observed in 2009 was very similar to findings by Lafleur and Humphreys (2008) and to other eddy covariance and plot scale results obtained in arctic environments (Vourlitis and Oechel, 1999; Christensen et al., 2000; Vourlitis et al., 2000; Corradi et al., 2005; Kwon et al., 2006; Sullivan et al., 2008). The season began with small net daily losses of $\mathrm{CO}_{2}$ after snowmelt but gradually increased until maximum $\mathrm{CO}_{2}$ uptake was reached about 3 weeks after summer solstice (DOY 206 to 214) and then decreased thereafter. The mid-summer daily flux during 2009 ranged between -0.8 and $-2.2 \mathrm{~g} \mathrm{C} \mathrm{m}^{-2}$ day $^{-1}$ with an average of $-1.5 \pm 0.1 \mathrm{~g} \mathrm{C} \mathrm{m}^{-2}$ day $^{-1}( \pm \mathrm{SE})$. The magnitude of $\mathrm{CO}_{2}$ exchange at the Daring Lake fen falls in the middle of observations from a number of other arctic sedge-dominated ecosystems (Vourlitis and Oechel, 1999; Vourlitis et al., 2000; Corradi et al., 2005; Kwon et al., 2006). For example, the ecosystem GP $\max$ in this study, $-7.1 \mu \mathrm{mol} \mathrm{m} \mathrm{m}^{-2} \mathrm{~s}^{-1}$, is very similar to the value obtained for a sedge fen in Alaska $\left(-6.7 \mu \mathrm{mol} \mathrm{m} \mathrm{m}^{-2} \mathrm{~s}^{-1}\right.$ to $\left.-8.0 \mu \mathrm{mol} \mathrm{m}^{-2} \mathrm{~s}^{-1}\right)$, while a moist 
tussock shrub ecosystem located within $2.5 \mathrm{~km}$ reported a higher $\mathrm{GP}_{\max }$ value of -8.2 $\mu \mathrm{mol} \mathrm{m} \mathrm{s}^{-1}$ to $-12.3 \mu \mathrm{mol} \mathrm{m}{ }^{-2} \mathrm{~s}^{-1}$ (Vourlitis et al., 2000). The daily maximum $\mathrm{CO}_{2}$ uptake $\left(-2.2 \mathrm{~g} \mathrm{C} \mathrm{m}^{-2}\right.$ day $\left.^{-1}\right)$ at the Daring Lake fen was smaller than the daily maximum $\mathrm{CO}_{2}$ gain $\left(-5.4 \mathrm{~g} \mathrm{C} \mathrm{m}^{-2}\right.$ day $\left.^{-1}\right)$ observed by Kwon et al. (2006) in a 5 year study of a sedge fen ecosystem in Alaska. Overall, the ecosystem average of $-1.5 \mathrm{~g} \mathrm{C} \mathrm{m}^{-2} \mathrm{day}^{-1}$ at Daring Lake is very similar to the average flux observed in an Alaskan sedge fen ecosystem $(-1.3$ $\mathrm{g} \mathrm{C} \mathrm{m}^{-2}$ day ${ }^{-1}$ to $-1.9 \mathrm{~g} \mathrm{C} \mathrm{m}^{-2}$ day $^{-1}$ ) (Vourlitis et al., 2000), more negative (more $\mathrm{CO}_{2}$ uptake) than $-0.5 \mathrm{~g} \mathrm{C} \mathrm{m}^{-2}$ day $^{-1}$ reported by Corradi et al. (2005) in a wet tussock grassland in north-east $\mathrm{Siberia,}$ and more negative than -0.5 to $-0.6 \mathrm{~g} \mathrm{C} \mathrm{m}^{-2}$ day ${ }^{-1}$ reported by Vourlitis and Oechel (1999) over a two year study in a moist tussock ecosystem in the Happy Valley of Alaska. Griffis et al. (2000) reported a small daily average ecosystem $\mathrm{CO}_{2}$ flux of $-0.7 \mathrm{~g} \mathrm{C} \mathrm{m}^{-2} \mathrm{day}^{-1}$ for the growing season in a very similar sedge fen to Daring Lake located in the low Arctic near Churchill, Manitoba. The water table at the Churchill site was considerably lower during peak biomass period (DOY $173-220$ ) and may have resulted in increased ER and less negative GEP, resulting in the smaller magnitude for NEE. In fact, during mid-summer at the Churchill fen, there was even less $\mathrm{CO}_{2}$ uptake with average ecosystem NEE of $-0.3 \mathrm{~g} \mathrm{C} \mathrm{m}^{-2}$ day $^{-1}$.

Plot scale $\mathrm{GP}_{\max }$ of $-6.2 \mu \mathrm{mol} \mathrm{m} \mathrm{s}^{-2} \mathrm{~s}^{-1}$ and $-6.3 \mu \mathrm{mol} \mathrm{m}^{-2} \mathrm{~s}^{-1}$ for lawns and tussocks, respectively, were in good agreement with ecosystem $\mathrm{GP}_{\max }\left(-7.1 \mu \mathrm{mol} \mathrm{m} \mathrm{m}^{-2}\right)$, while average daytime field measurements of NEE were less negative $\left(-2.0 \mathrm{~g} \mathrm{C} \mathrm{m}^{-2} \mathrm{day}^{-1}\right.$ and $1.9 \mathrm{~g} \mathrm{C} \mathrm{m}^{-2}$ day $^{-1}$ lawns and tussocks, respectively) than the average daytime ecosystem flux $\left(-2.9 \mathrm{~g} \mathrm{C} \mathrm{m}^{-2} \mathrm{day}^{-1}\right)$. Our results were similar to a study by Sullivan $e$ al. (2008), where under light saturating conditions (PAR $>1000 \mu \mathrm{mol} \mathrm{m}^{-2} \mathrm{~s}^{-1}$ ) the range of mid-day 
$\mathrm{CO}_{2}$ flux in hummocks was $-0.7 \mathrm{~g} \mathrm{C} \mathrm{m}^{-2}$ day $^{-1}$ to $-2.2 \mathrm{~g} \mathrm{C} \mathrm{m}^{-2}$ day ${ }^{-1}$ and in lawns was -1.1 $\mathrm{g} \mathrm{C} \mathrm{m}^{-2}$ day $^{-1}$ to $-2.0 \mathrm{~g} \mathrm{C} \mathrm{m}^{-2}$ day $^{-1}$ at a Greenland fen with a similar microtopography and vascular species composition to Daring Lake. Another chamber flux study in a high arctic sedge fen ecosystem in Greenland with tussock and lawn topography report a larger range in NEE $\left(-2.2 \mathrm{~g} \mathrm{C} \mathrm{m}^{-2}\right.$ day $^{-1}$ to $-0.4 \mathrm{~g} \mathrm{C} \mathrm{m}^{-2}$ day $\left.^{-1}\right)$, with larger uptake rates associated with tussock topography and smaller rates associated with lawns (Christensen et al., 2000). The magnitude of our lawn and tussock $\mathrm{CO}_{2}$ flux results are quite large when compared to the averages of $-0.24 \mathrm{~g} \mathrm{C} \mathrm{m}^{-2}$ day $^{-1}$ hummocks and $0.05 \mathrm{~g} \mathrm{C} \mathrm{m}^{-2} \mathrm{day}^{-1}$ for hollows reported by Griffis et al. (2000) in the Churchill low arctic sedge fen. Differences in species composition, duration of the study period, and WT may account for the differences in observed NEE.

Seasonal patterns in daily ecosystem and small plot scale $\mathrm{CH}_{4}$ emissions were similar to the pattern observed by Riutta et al. (2007) and to other eddy covariance and plot scale studies in northern and arctic sedge fen dominated ecosystems (Christensen et al., 2000; Friborg et al., 2000; Corradi et al., 2005; Wille et al., 2008). In contrast, at a high arctic wet tundra ecosystem, no significant variation in seasonal $\mathrm{CH}_{4}$ emission was observed (Sachs et al., 2008). The beginning of the study started off with approximate $\mathrm{CH}_{4}$ emissions of $25 \mathrm{mg} \mathrm{CH}_{4} \mathrm{~m}^{-2}$ day ${ }^{-1}$ and increased to maximum mid-summer values between $55 \mathrm{mg} \mathrm{CH}_{4} \mathrm{~m}^{-2}$ day $^{-1}$ and $69 \mathrm{mg} \mathrm{CH}_{4} \mathrm{~m}^{-2}$ day $^{-1}$ and then decreased to similar values observed at the beginning of the study. These emissions were almost twice as large as those observed by Sachs et al. (2008) in a high arctic wet tundra ecosystem (35 $\mathrm{mg} \mathrm{CH} 4 \mathrm{~m}^{-2}$ day $^{-1}$ ), in a Siberian arctic polygonal tundra ecosystem (30 $\mathrm{mg} \mathrm{CH}_{4} \mathrm{~m}^{-2}$ day $^{-1}$, Wille et al. 2008), and in a low arctic Finnish fen ( $38 \mathrm{mg} \mathrm{CH}_{4} \mathrm{~m}^{-2}$ day ${ }^{-1}$, Hargreaves et 
al., 2001). However, Daring Lake $\mathrm{CH}_{4}$ emissions were almost half the reported $\mathrm{CH}_{4}$ emission in a high arctic Greenland fen $\left(120 \mathrm{mg} \mathrm{CH}_{4} \mathrm{~m}^{-2}\right.$ day $^{-1}$, Friborg et al., 2000) and in a northern boreal treed fen (103.6 $\mathrm{mg} \mathrm{CH}_{4} \mathrm{~m}^{-2} \mathrm{day}^{-1}$, Long et al., 2010).

Plot scale measurements were also quite variable within and among sites. The range of $\mathrm{CH}_{4}$ emission for lawns at Daring Lake was between $11 \mathrm{mg} \mathrm{CH}_{4} \mathrm{~m}^{-2}$ day $^{-1}$ and $227 \mathrm{mg} \mathrm{CH}_{4} \mathrm{~m}^{-2}$ day ${ }^{-1}$ with an average of $80 \mathrm{mg} \mathrm{CH}_{4} \mathrm{~m}^{-2}$ day-1 over the study period; while, tussock fluxes were considerably lower with a range between $3 \mathrm{mg} \mathrm{CH}_{4} \mathrm{~m}^{-2}$ day $^{-1}$ and $110 \mathrm{mg} \mathrm{CH}_{4} \mathrm{~m}^{-2}$ day $^{-1}$ with an average of $48 \mathrm{mg} \mathrm{CH}_{4} \mathrm{~m}^{-2}$ day $^{-1}$. Contrary to results at Daring Lake, a few northern and arctic sedge fen chamber studies have reported no significant difference between lawn and tussock $\mathrm{CH}_{4}$ emission (Corradi et al., 2005; Riutta et al., 2007). Corradi et al. (2005) reported a higher average $\mathrm{CH}_{4}$ emission from a Siberian wet tussock grassland of $195.8 \pm 80.7 \mathrm{mg} \mathrm{CH}_{4} \mathrm{~m}^{-2}$ day ${ }^{-1}$, while Riutta et al. (2007) also reported higher $\mathrm{CH}_{4}$ emissions of approximately $240 \mathrm{mg} \mathrm{CH}_{4} \mathrm{~m}^{-2}$ day ${ }^{-1}$ during the peak of growing season in a northern Finnish fen. In a high arctic fen, characterized by lawn and tussock microtopography similar to the Daring Lake fen, Christensen et al. (2000) reported a comparable average lawn $\mathrm{CH}_{4}$ flux of $218 \mathrm{mg} \mathrm{CH}_{4}$ $\mathrm{m}^{-2}$ day $^{-1}$ and average tussock $\mathrm{CH}_{4}$ flux of $68 \mathrm{mg} \mathrm{CH}_{4} \mathrm{~m}^{-2}$ day ${ }^{-1}$ which was slightly higher than our reported averages yet within our observed $\mathrm{CH}_{4}$ flux range. Overall, summer $\mathrm{CH}_{4}$ emissions were consistent with the range of average summer $\mathrm{CH}_{4}$ flux (-1.3 to 255 $\mathrm{mg} \mathrm{CH}_{4} \mathrm{~m}^{-2}$ day $^{-1}$ ) summarized by Liblik et al. (1997) for other northern and arctic plot scale studies. 


\subsection{Growing Season Carbon Budget and GWP}

Estimated growing season (June 1 - August 31, 92 days) flux of $\mathrm{CO}_{2}$ and $\mathrm{CH}_{4}$, and DOC runoff were $-66.3,2.4$, and $0.9 \mathrm{~g} \mathrm{C} \mathrm{m}^{-2}$, with an overall $\mathrm{C}$ budget of $-63.0 \mathrm{gC}$ $\mathrm{m}^{-2}$. This cumulative net $\mathrm{CO}_{2}$ exchange is similar to two Alaskan sedge fen tundra campaigns $\left(\mathrm{CH}_{4}\right.$ and DOC were not measured) $\left(-76.8 \mathrm{~g} \mathrm{C} \mathrm{m}^{-2}, 92\right.$ days; $-70 \mathrm{~g} \mathrm{C} \mathrm{m}^{-2}, 92$ days) (Vourlitis et al., 2000; Kwon et al., 2006, respectively). However, it is important to note that there is considerable year-to-year variability in growing season NEE. For example, $\mathrm{NEE}$ varied from $-46.4 \mathrm{~g} \mathrm{C} \mathrm{m}^{-2}$ to $-70 \mathrm{~g} \mathrm{C} \mathrm{m}^{-2}$ over a 5 year period in an Alaskan sedge fen tundra campaign (Kwon et al., 2006) and from -39.9 to $-55.2 \mathrm{~g} \mathrm{C} \mathrm{m}^{-2}$ over 2 years in an Alaskan moist tussock ecosystem (Vourlitis and Oechel, 1999). Over a nine week study (63 days) in 2004, a Siberian high-arctic fen reported almost half the uptake of $\mathrm{CO}_{2}\left(-33.8 \pm 6.0 \mathrm{~g} \mathrm{C} \mathrm{m}^{-2}\right)$ reported at Daring Lake in 2009 (Grondahl et al., 2008); while, during a similar eight and a half week time period (60 days), a Siberian arctic sedge wetland ecosystem was a much bigger sink $\left(-100 \mathrm{~g} \mathrm{C} \mathrm{m}^{-2}\right)$ (Corradi et al., 2006).

Total $\mathrm{CH}_{4}$ emitted by the Daring Lake fen (June 1 to August 31, 92 days, $2.4 \mathrm{~g} \mathrm{C}$ $\mathrm{m}^{-2}$ ) was within the range of growing season fluxes reported in a northern Siberian wet tundra ecosystem (June 1 to September 30, 122 days, $1.9 \mathrm{~g} \mathrm{C} \mathrm{m}^{-2}$ ) (Sachs et al., 2008), in a Siberian wet polygonal tundra ecosystem (June 9 to September 19, 103 days, $1.9 \mathrm{~g} \mathrm{C} \mathrm{m}^{-}$

${ }^{2}$ ) (Wille et al., 2008), and in a Greenland high-arctic wet fen (June 1 to September 1, 93 days, $3.7 \mathrm{~g} \mathrm{C} \mathrm{m}^{-2}$ ) (Friborg et al., 2000). 
Due to the scarcity of DOC flux investigation in arctic peatland environments, there lacks a suitable comparison to the Daring Lake study; however, in a subarctic Alaskan catchment, Carey (2003) found the yearly flux to be approximately twice our reported growing season value $\left(1.6 \mathrm{~g} \mathrm{C} \mathrm{m}^{-2}\right.$ vs. $\left.0.9 \mathrm{~g} \mathrm{C} \mathrm{m}^{-2}\right)$. Given that $69 \%$ of DOC export occurred during the spring snowmelt period (Carey, 2001), it is likely that DOC flux at Daring Lake could be much larger if continuous measurements of outflow were made during summer capturing rainfall events and if spring freshet and fall storm periods were included.

Carbon budget comparisons are complicated due to the abiotic and biotic variables which are sensitive to site-specific characteristics. Variations in these variables can result in dramatically different $\mathrm{C}$ budgets within and among sites and year to year. While many studies do not include a complete $\mathrm{C}$ budget, and the inclusion of $\mathrm{CH}_{4}$ and DOC fluxes may not change the overall $\mathrm{C}$ sink/source magnitude of an ecosystem, the inclusion of these smaller fluxes can be very important where the sink/source magnitude is close to zero. In our study, $\mathrm{CH}_{4}$ emission and DOC loss represented approximately 5 $\%$ of the total amount of C stored through NEE during the growing season. In comparison, in a boreal ombrotrophic peatland, annual DOC export $\left(8.2 \mathrm{~g} \mathrm{C} \mathrm{m}^{-2}\right)$ was approximately $12 \%$ of the annual amount of $\mathrm{C}$ taken up through $\mathrm{CO}_{2}$ exchange $(-71 \mathrm{~g} \mathrm{C}$ $\mathrm{m}^{-2}$ ) (Fraser et al., 2001). In a British upland peat catchment, annual DOC loss was $6 \%$ while $\mathrm{CH}_{4}$ emission accounted for approximately $13 \%$ of annual $\mathrm{C}$ taken up through $\mathrm{CO}_{2}$ exchange, resulting in a $\mathrm{C}$ budget decrease from approximately $-55 \mathrm{~g} \mathrm{C} \mathrm{m}^{-2}$ to $-36 \mathrm{~g} \mathrm{C} \mathrm{m}^{-2}$ annually (Worrall et al., 2003). Friborg et al. (2003) estimated that $\mathrm{CH}_{4}$ emissions accounted for approximately $6.5 \%$ of $\mathrm{C}$ taken up through $\mathrm{CO}_{2}$ exchange in a Siberian 
boreal wetland. Wille et al. (2008) estimated that $\mathrm{CH}_{4}$ emissions represented $14 \%$ of the annual $\mathrm{C}$ budget of a Siberian wet polygonal ecosystem.

Although estimates of the annual $\mathrm{C}$ budget of the Daring Lake fen are beyond the scope of this study, it is expected that including spring and fall periods would increase the $\%$ contribution of $\mathrm{CH}_{4}$ and DOC exchange as NEE becomes positive during these periods (Lafleur and Humphreys, 2008). Panikov (1999) report winter and spring fluxes to be an important part of the annual $\mathrm{CH}_{4}$ and $\mathrm{CO}_{2}$ budget, with some studies reporting 5 to $50 \%$ of yearly flux during these periods. Elberling et al. (2008) suggest that large bursts of $\mathrm{CO}_{2}$ and $\mathrm{CH}_{4}$ during spring thaw indicate the importance of winter soil respiration and microbial action, while the autumn period when snowfall covers and insulates the ground, keeping soil warm, will extend periods of high $\mathrm{ER}$ and $\mathrm{CH}_{4}$ production furthering the importance of non-growing season fluxes on annual $\mathrm{C}$ budgets.

The inclusion of a GWP budget, at the 20 year and 100 year timescale, and its associated radiative forcing potential on the atmosphere should be viewed and interpreted with caution. The GWP methodology (IPCC, 2007) and its calculated radiative forcing potential to either warm or cool the atmosphere is highly dependent upon time horizon selection (Frolking et al., 2006). Uptake and emission $\left(\mathrm{CO}_{2}\right.$ and $\left.\mathrm{CH}_{4}\right)$ reported using GWP methodology in C cycling studies are generally treated as isolated perturbations or pulses to constant atmospheric concentrations; however, GWP should be determined over the lifetime of an ecosystem, as peatlands do not store or emit greenhouse gases in an isolated annual pulse; rather, they persistently emit $\mathrm{CH}_{4}$ and variably, spatially and temporally, either emit or store $\mathrm{CO}_{2}$ (Frolking et al., 2006). Frolking et al. (2006) used atmospheric budget models and time series estimates to assess the impact of sustained or 
variable greenhouse gas emissions on radiative forcing potential over the lifetime of an ecosystem. Frolking et al. (2006) report that constant $\mathrm{CH}_{4}$ emissions from northern peatlands maintain atmospheric concentrations, while a change in $\mathrm{CH}_{4}$ emission will result in a net positive radiative forcing over a few decades and then will neutralize; while, constant $\mathrm{C}$ sequestration via $\mathrm{CO}_{2}$ exchange results in a constant negative radiative forcing over an ecosystem's lifetime. For northern peatland, a net positive radiative forcing effect will occur for approximately the first 50 years, while diminishing positive radiative forcing effects are seen over the next hundred to several millennia, dependent upon $\mathrm{C}$ sequestration rates, and thereafter, the peatland will have net negative radiative forcing effect (cooling) on the atmosphere (Frolking et al., 2006). 


\subsection{CONCLUSION}

Arctic peatland ecosystems store vast quantities of $\mathrm{C}$, much of which is stored in perennially frozen soil. Enhanced mineralization of this $\mathrm{C}$ as a result of climate change is a potentially significant positive feedback to the global climate system. Recently, much investigation into the biotic and abiotic controls that drive the dynamic processes that control the amount of $\mathrm{C}$ that is either stored or released within wetland environments has taken place outside of Canada (Christensen et al., 1995; Christensen et al., 2000; Friborg et al., 2000; Friborg et al., 2003; Corradi et al., 2005; Grondahl et al., 2008; Sullivan et al., 2008; Wille et al., 2008), but there have been very few studies in Canada's low or high Arctic (Welker et al., 2004; Oberbauer et al., 2007; Hayne, 2009; Wilson and Humphreys, 2010), facilitating the need for investigation into spatial and temporal controls on $\mathrm{C}$ flux dynamics in an area expected to see dramatic climatic change in the near future.

This study examined temporal and spatial variations in $\mathrm{CO}_{2}$ and $\mathrm{CH}_{4}$ fluxes within a Canadian low Arctic peatland to test the following hypotheses:

1) During the study period, the sedge fen is a $\mathrm{C}$ sink with more $\mathrm{C}$ taken up as $\mathrm{CO}_{2}$ than lost as $\mathrm{CH}_{4}$ and $\mathrm{DOC}$.

The Daring Lake fen was a $\mathrm{C}$ sink of $63 \mathrm{~g} \mathrm{C} \mathrm{m}^{-2}$ over the growing season. The relative $\mathrm{C}$ budget components at the Daring Lake fen were within the range observed at other sedge-dominated arctic systems but smaller in magnitude to other $\mathrm{C}$ budget studies within wetland environments at lower latitudes. $\mathrm{CH}_{4}$ and $\mathrm{DOC}$ losses were small relative to growing season $\mathrm{CO}_{2}$ uptake $(5 \%)$ but are expected to be of greater importance on an 
annual basis. In order to accurately determine the sink/source magnitude of an area, measurements during the spring, fall, and winter are necessary. During these periods, there is the potential to lose the $\mathrm{C}$ gained during the growing season but further study will be necessary to determine if this is the case at the Daring Lake fen.

2) Temporal and spatial variability in $\mathrm{CO}_{2}$ flux is influenced most by factors that influence photosynthesis such as leaf area, light, and temperature.

Lawn and tussock microtopography within the fen resulted in no significant differences in NEE. Instead, \% vascular cover and LAI drove variations in NEE among collars regardless of microtopographic position.

Temporal variations in NEE were controlled by changes in air temperature and PAR, resulting in significant variation over the study period at the plot and ecosystem scales. At the plot scale, warmer, sunnier conditions enhanced uptake and release of $\mathrm{CO}_{2}$; however, uptake (GEP) was enhanced to a greater extent than release (ER), resulting in greater overall C uptake (NEE) on warmer, sunny days. Both plot and ecosystem scale peaked at the same time during the mid-summer when biomass was greatest, light was not limiting, and temperatures were high.

3) Temporal and spatial variability in $\mathrm{CH}_{4}$ flux is influenced most by factors that affect anaerobic decomposition such as soil moisture conditions and soil temperatures.

Emissions of $\mathrm{CH}_{4}$ were significantly greater in wetter lawns than drier tussocks. There was little temporal variation in $\mathrm{CH}_{4}$ fluxes at the plot scale likely as a result of 
relatively constant moisture conditions (VWC). However, at the ecosystem scale, $\mathrm{CH}_{4}$ emissions peaked with NEE and were related to variations in temperature and friction velocity. The persistent reduction in $\mathrm{CH}_{4}$ emissions with high sustained turbulence has not been reported and more investigation is necessary to determine the reasons for this observation. 


\subsection{REFERENCES}

ACIA, Impacts of a Warming Arctic: Arctic Climatic Impact Assessment. Cambridge University Press, 2004.

Aurela M, Riutta T, Laurila T, Tuovinen JP, Vesla T, Tuittila ES, Rinne J, Haapanala S, Laine $\mathrm{J}(2007) \mathrm{CO}_{2}$ exchange of a sedge fen in southern $\mathrm{F}$ inland - the impact of a drought period. Tellus, 59B, 826-837.

Alexandrova, VD (1980) The Arctic and Antarctic: Their Division into Geobotanical Areas. Cambridge University Press, Cambridge, UK.

Baldocchi D (2003) Assessing the eddy covariance technique for evaluating carbon dioxide exchange rates of ecosystems: past, present and future. Global Change Biology, 9, 479-492.

Bartlett KB, Harriss RC. (1993) Review and Assessment of Methane emissions from Wetlands. Chemosphere, 26, 311-320.

Barber KE (1981) Peat Stratigraphy and Climatic Change: a Palaecological Test of Cyclic Peat Bog Regeneration. AA Balkema, Rotterdam.

Basilika N, Moore TR, Jeannotte R, Bubier JL (2006) Nutrient input and Carbon and Microbial Dynamics in an Ombrotrophic Bog. Geomicrobiology Journal, 23, 531543.

Bear J (1972) Dynamics of Fluids in Porous Media. Dover Publications, Mineola, New York, USA.

Bellisario LM, Bubier JL, Moore TR (1999) Controls on $\mathrm{CH}_{4}$ emissions from a northern peatland. Global Biogeochemical Cycles, 13:1, 81-91.

Bliss LC (1997) Arctic ecosystems of North America. Polar and alpine tundra. Elsevier, Amsterdam, NL, 509 - 539.

Bockheim JG, Everett LR, Hinkel KM, Nelson FE, Brown J (1999) Soil organic carbon storage and distribution in arctic tundra, Borrow, Alaska. Soil Science Society of America Journal, 63, 934-940.

Bubier JL, Moore TR (1994) An Ecological Perspective on Methane Emissions from Northern Wetlands. Trends in Ecology and Evolution, 9:12, 460-464.

Bunnell FL, Tait DEN, F lanagan PW (1977) Microbial Respiration and Substrate Weight Loss - II. A Model of the Influences of Chemical Composition. Soil Biol.

Biochem., 9, 41-47. 
Burn CR, Nelson FE. (2006). Comment on "A projection of severe near-surface perma frost degradation during the 21st century" by David M. Lawrence and Andrew G. Slater. Geophysical Research Letters, 33: L21503.

Bushaw KL, Zepp RG, Tarr MA, Schulz-Janders D, Bourbonniere RA, Hodson RE, Miller WL, Bronk DA, Moran MA (1996) Photochemical release of biologically available nitrogen from aquatic dissolved organic matter. Nature, 381, 404-407.

Callaghan TV, Björn LO, Chernov Y, Chapin T, Christensen TR, Huntley B, Ims RA, Johansson M, Jolly D, Jonasson S, Matveyeva N, Panikov N, Oechel W, Shaver $\mathrm{G}$ (2005) Effects on the Function of Arctic Ecosystems in the Short- and Longterm Perspectives. Arctic Climate Impacts Assessment (ACIA), C. Symon, L. Arris and B. Heal, Eds.,Cambridge University Press, Cambridge, 21-60.

Carey, S (2003) Dissolved Organic Carbon Fluxes in a Discontinuous Permafrost Subarctic Alpine Catchment. Permafrost and Periglacial Processes, 14, 161-171.

Chanton JP, Whiting GJ (1995) Trace gas exchange in freshwater and coastal marine environments: Ebullitionand transport by plants. In Matson, P. A. and Harriss, R. C. (eds.) Biogenic Trace Gases: Measuring Emissions fromSoil and Water. Blackwell, Oxford. pp. 98-125.

Chapin FS, Kittel TGF, Steffen WL (2000) Global and regional modeling of Arcticboreal vegetation distribution and its sensitivity to altered forcing. Global Change Biology, 6, 1-18.

Christensen TR (1993) Methane emission from Arctic tundra. Biogeochemistry, 21, 117139.

Christensen TR, Jonasson S, Callaghan TV, Havstrom M (1995). Spatial variation in high-latitude methane flux along a transect across Siberian and European tundra environments. Journal of Geophysical Research, 100, 21035-21045.

Christensen TR, Prentice IC, Kaplan J, Haxeltine AM, Sitch S (1996) Methane flux from northern wetlands and tundra: an ecosystem source modelling approach. Tellus, 48, 652-661.

Christensen TR, Friborg T, Sommerkorn M, Kaplan J, Illeris L, Soegaard H, Nordstroem $\mathrm{C}$, Jonasson S (2000) Trace gas exchange in a high-arctic valley 1 . Variations in $\mathrm{CO}_{2}$ and $\mathrm{CH}_{4}$ flux between tundra vegetation types. Global Biogeochemical Cycles, 14, 701-713

Clark JM, Lane SN, Chapman PJ, Adamson JK (2007) Export of dissolved organic carbon from and upland peatland during storm events: Implications for flux estimates. Journal of Hydrology, 347, 438-447. 
Climatic Atlas of Canada (1984) Map Series 1 \& 2. Government of Canada, Ottawa, ON.

Corradi C, Kolle O, Walter K, Zimov SA, Schulze ED (2005) Carbon dioxide and methane exchange of a north-east Siberian tussock tundra. Global Change Biology, 11, 1910-1925.

Davidson EA, Janssens IA. (2006). Temperature sensitivity of soil carbon decomposition and feedbacks to climate change. Nature, 440: 165-173.

Dedysh SN, Khmelenia VN, Suzina NE, Trotsenko YA, Semrau JD, Liesack W, Tiedje JM (2002) Methylocapsaacidiphilagen. nov., sp. nov., anovel methane-oxidizing and dinitrogen-fixingacidophilic bacterium from Sphagnum bog. International Journal of Systematic and Evolutionary Microbiology, 52, 251-261.

Dredge LA, Kerr DE, Wolfe SA (1999). Surficial materials and related ground ice conditions, S lave Province, N.W.T., Canada. Canadian Journal of Earth Science, 36, $1227-1238$.

Elberling B (2007) Annual soil $\mathrm{CO}_{2}$ effluxes in the High Arctic: The role of snow thickness and vegetation type. Soil Biology \& Biochemistry, 39, 646-654.

Elberling B, Nordstrom C, Grondahl L, Sogaard H, Friborg T, Christensen TR, Strom L, Marchand F, Nijs I (2008) High-arctic soil CO2 and CH4 production controlled by temperature, water, freezing and snow. Advances in Ecological Research, 40: 441-472.

Fan SM, Wolfsy, SC, Bakwin PS, Jacob DJ (1992) Micrometeorological measurements of $\mathrm{CH} 4$ and $\mathrm{CO} 2$ exchange between the atmosphere and subarctic tundra. Journal of Geophysical Research, 97, 16627-16643.

Fox AM, Huntley B, Lloyd CR, Williams M, Baxter R (2008) Net ecosystem exchange over heterogeneous Arctic Tundra: Scaling between chamber an eddy covariance measurements. Global Biogeochemical Cycles, 22, GB2027.

Fraser CJD, Roulet NT, Moore TR (2001) Hydrology and dissolved organic carbon biogeochemistry in an ombrotrophic bog. Hydrological processes, 15, 3151-3166.

Fribog T, Christensen TR, Hansen BU, Nordstroem C, Soegaard H (2000) Trace gas exchange in a high-arctic valley 2 . Landscape $\mathrm{CH}_{4}$ fluxes measured and modeled using eddy correlation data. Global Biogeochemical Cycles, 14 (3), 715-723.

Friborg T, Soegaard H, Christensen TR, Lloyed CR, Panikov NS (2003) Siberian wetlands: Where a sink is a source. Geophysical Research Letters, 30:21, 2129 2132. 
Frolking S, Roulet N, Fuglestvedt J (2006) How northern peatlands influence the Earth's radiative budget: Sustained methane emission versus sustained carbon sequestration. Journal of Geophysical Research, 111, G01008.

Gazovic M, Kutzbach L, Schreiber P, Wille C, Wilmking M (2010) Diurnal dynamics of $\mathrm{CH}_{4}$ from a boreal peatland during snowmelt. Tellus, 62B, 133-139.

Gergel SE, Turner MG, Kratz TK (1999) Dissolved organic carbon as an indicator of the scale of watershed influence on lakes and rivers. Ecological Applications,9,13771390.

Gorham E (1991) Northern Peatlands: Role in the Carbon Cycle and Probable Responses to Climate Warming. Ecological Applications, 1 (2), 182-195.

Granberg G, Mikkela C, Sundh I, Svensson BH, Nilsson M (1997) Sources of spatial variation in methane emission from mires in northern Sweden: A mechanistic approach in statistical modelling. Global Biogeochemical Cycles, 11, 135-150.

Griffis TJ, Rouse WR, Waddington JM (2000) Interannual variability of net ecosystem $\mathrm{CO}_{2}$ exchange at a subarctic fen. Global Change Biology, 7, 511-530.

Griffis TJ, Rouse WR, Waddington JM (2000) Scaling net ecosystem $\mathrm{CO}_{2}$ exchange from the community to landscape-level at a subarctic fen. Global Change Biology, $\mathbf{6}$, 459-473.

Grondahl L, Friborg T, Christensen TR, Ekberg A, Elberling B, Illeris L, Nordstrom C, Rennermalm A, Sigsgaard C, Sogaard H (2008) Spatial and Inter-Annual Variability of Trace Gas Fluxes in a Heterogeneous High-Arctic Landscape. Advances in Ecological Research, 40, 473-498.

Hayne S (2009) Controls on Atmospheric Exchanges of Carbon Dioxide and Methane for a Variety of Arctic Tundra Types. M.Sc. Thesis, Carleton University.

Heikkinen JEP, Elsakov V, Martikainen PJ (2002) Carbon dioxide and methane dynamics and annual carbon balance in tundra wetland in NE Europe, Russia. Global Biogeochemical Cycles, 16(4),1115.

Heikkinen JEP, Maljanen M, Aurela M, Hargreaves KJ, Martikainen PJ (2002) Carbon dioxide and methane dynamics in a sub-Arctic peatland in northern Finland. Polar Research, 21(1), 49-62.

Hornibrook ERC, Longstaffe FJ, Fyfe WS (1997) Spatial distribution of microbial methane production pathways in temperate zone wetland soils: Stable carbon and hydrogen isotope evidence. Geochimica et CosmochimicaActa, 61 (4), 745-753. 
Intergo vernmental Panel on Climate Change, IPCC (2007) Climate Change 2007, Synthesis Report, Contribution of Working Groups I, II and III to the Fourth Assessment. Report of the Intergovernmental Panel on Climate Change (Core Writing Team; Pachauri RK, Reisinger A(eds)). IPCC, Geneva, Switzerland.

IPCC, 2001: Climate Change 2001: The Scientific Basis. Contribution of Working Group I to the Third Assessment Report of theIntergovernmental Panel on Climate Change [Houghton, J.T., Y. Ding, D.J. Griggs, M. Noguer, P.J. van der Linden, X. Dai, K.Maskell, and C.A. Johnson (eds.)]. Cambridge University Press, Cambridge, United Kingdom and New York, NY, USA, 881pp.

Johnson LC, Damman AWH (1991) Species-controlled Sphagnum decay on a South Swedish raised bog. Oikos, 61, 234-242.

Kalbitz K, Solinger S, Park J-H, Michalzik B, Matzner E (2000) Controls on the dynamics of dissolved organic matter in soils: a review. Soil Science 165: 277304.

Kellner E, Waddington JM, Price JS (2005) Dynamics of biogenic gas bubbles in peat: Potential effects on water storage and peat deformation. Water Resources Research, 41, W08417.

King JY, Reeburgh WS, Regli SK (1998) Methane emission and transport by arctic sedges in Alaska: Results of a vegetation removal experiment. Journal of Geophysical Research, 103 (D22), 29083-29092.

Kuhry P, Dorrepaal E, Hugelius G, Schuur EAG, Tarnocai C (2010) Potential Remobilization of Belowground Permafrost Carbon under F uture Global Warming. Permafrost and Periglacial Processes, 21, 208-214.

Kutzbach L, Wagner D, Pfeiffer E-M (2004) Effect of microrelief and vegetation on methane emissions from wet polygonal tundra, Lena Delta, Northern Siberia. Biogeochemistry, 69, 341-362.

Kutzbach L, Schneider J, Sachs T, Giebels M, Nykanen H, Shurpali NJ, Martikainen PJ, Alm J, Wilmking $\mathrm{M}(2007) \mathrm{CO}_{2}$ flux determination by closed-chamber methods can be seriously biased by inappropriate application of linear regression. Biogeosciences, 4, 1005-1025.

Kwon HJ, Oechel WC, Zulueta RC, Hastings SJ (2006) Effects of climate variability on carbon sequestration among adjacent wet sedge tundra and moist tussock tundra ecosystems. Journal of Geophysical Research, 111, G03014.

Lafleur PM, Griffis TJ, Rouse WR (2001) Interannual variability in net ecosystem $\mathrm{CO}_{2}$ exchange at the arctic treeline. Arctic, Antarctic, and Alpine Research, 33, 149157. 
Lafleur PM, Humphreys ER (2008) Spring warming and carbon dioxide exchange over low Arctic tundra in central Canada. Global Change Biology, 14, 740-756.

Lai DYF (2009) Methane dynamics in northern peatlands: A review. Pedosphere, 19, 409-421.

Liblik LK, Moore TR, Bubier JL, Robinson SD (1997) Methane emissions from wetlands in the zone of discontinuous permafrost: Fort Simpson, Northwest Territories, Canada. Global Biogeochemical Cycles, 11 (4), 485-494.

Llyod J, Taylor JA (1994) On the temperature dependence of sol respiration. Functional Ecology, 8, 315-323.

Long KD, F lanagan LB, Cai T (2010) Diurnal and seasonal variation in methane emissions in a northern Canadian peatland measured by eddy covariance. Global Change Biology, 16(9), 2420-2435.

Luo Y, Zhuo X (2006) Soil Respiration and the Environment. Burlington, MA, and San Diego, CA, USA: Academic Press pp. 320.

Merbold L, Kutsch WL, Corradi C, Kolle O, Rebmann C, Stoy PC, Zimov SA, Schulze ED (2009) Artificial drainage and associated carbon fluxes $\left(\mathrm{CO}_{2} / \mathrm{CH}_{4}\right)$ in a tundra ecosystem. Global Change Biology, 15, 2599-2614.

Moore TR, Basiliko N (2006). Decomposition. Boreal Peatland Ecosystems, 188, 126143.

Moore TR, Roulet NT, Waddington JM (1998) Uncertainty in predicting the effect of climatic change on the carbon cycling of Canadian peatlands. Climatic Change, 40: $229-245$.

Nilsson M, Sagerfors J, Buffam I, Laudon H, Eriksson T, Grelle A, Klemedtssons L, Wesliens P, Lindroth A (2008) Contemporary carbon accumulation in a boreal oligotrophicminerogenic mire - a significant sink after accounting for all Cfluxes. Global Change Biology, 14, 2317-2332.

Nobrega S, Grogan P (2008) Landscape and Ecosystem-Level Controls on Net Carbon Dioxide Exchange along a Natural Mo isture Gradient in Canadian Low Arctic Tundra. Ecosystems, 11, 377-396.

Nungesser MK (2003) Modelling microtopography in boreal peatlands: hummocks and hollows. Ecological Modelling, 165, 175-207. 
Nykanen H, Heikkinen JEP, Pirinen L, Tiilikaninen K, Martikainen PJ (2003) Annual $\mathrm{CO}_{2}$ and $\mathrm{CH}_{4}$ fluxes on a subarctic palsa mire during climatically different years. Global Biogeochemical Cycles, 17, 1801-1818.

Oberbauer SF, Tweedie CE, Welker JM, Fahnestock JT, Henry GHR, Webber PJ, Hollister RD, Walker MD, Kuchy A, Elmore E, Starr G (2007) Tundra $\mathrm{CO}_{2}$ fluxes in response to experimental warming across latitudinal and moisture grad ients. Ecological Monographs, 77 (2), 221-238.

Obst J (2008) Classification of Landcover, Vegetation Communities, Ecosystems and Habitats in the East Daring Lake Basin, Northwest Territories. Department of Environment and Natural Resources, Wildlife Division, Government of the Northwest Territories and Environment and Conservation Division, Indian and Northern Affairs Canada, Yellowknife, Northwest Territories.

Oechel WC, Hastings SJ, Vourlitis G, Jenkins M, Riechers G, Grulke N (1993) Recent change of Arctic tundra ecosystems from a carbon sink to a source. Nature, 361, $520-523$.

Oechel WC and Vourlitis GL (1994) The effects of climate-change on land atmosphere feedbacks in Arctic tundra regions. Trends in Ecology \& Evolution, 9 (9), 324329.

Oechel WC, Vourlitis GL, Hastings SJ, Ault R, Bryant P (1998) The effects of water table manipulation and elevated temperature on the net $\mathrm{CO}_{2}$ flux of a wet-sedge tundra ecosystem. Global Change Biology, 4, 77-90.

Oechel WC, Vourlitis GL, Hastings SJ, Zulueta RC, Hinzman L, Kane D (2000) Acclimation of ecosystem $\mathrm{CO}_{2}$ exchange in the Alaskan Arctic in response to decadal climate warming. Nature, 406, 978-981.

Ohlson M, Dahlberg B (1991) Rate of peat increment in hummock and lawn communities on Swedish mires during the last 150 years. Oikos, 61, 369-378.

Okolo I (2008) Analysis of Long Term Carbon Accumulation in an Arctic Fen. B.Sc Thesis, Institute for Environmental Science, Carleton University, Ottawa, ON.

Panikov N. S (1999) Fluxes of $\mathrm{CO}_{2}$ and $\mathrm{CH}_{4}$ in high latitude wetlands: measuring, modeling, and predicting response to climate change. Polar Research, 18, 237244.

Pastor J, So lin J, Bridgman SD, Updegraff K, Harth C, Weishampel P, Dewey B (2003) Global warming and the export of dissolved organic carbon from boreal peatlands. Oikos, 100, 380-386. 
Pawson RR, Lord DR, Evans MG, Allott THE (2008) F luvial organic carbon flux from an eroding peatland catchment, southern pennines, UK. Hydrol. Earth Syst. Sci., $12,625-634$.

Post WM, Emanuel WR, Zinke PJ, Strangenberger, AG (1982) Soil carbon pools and world life zones. Nature 298, 156-159.

Piquette S (2010) Quantification of Greenhouse Gas Flux and Net Ecosystem Exchange in Variable Ecosystems in the Daring Lake, NWT Area. Undergraduate Thesis in Physical Geography and Earth Science, Carleton University, Ottawa, Ontario, Canada.

Reth S, Reichstein M, Falge E (2005) The effect of soil water content, soil temperature, soil $\mathrm{pH}$-value and the root mass on soil $\mathrm{CO}_{2}$ efflux - A modified model Plant and Soil, 268, 21-33.

Rinne J, Riutta T, Pihlatie M, Aurela M, Haapanala S (2007) Annual cycle of methane emission from a boreal fen measured by the eddy covariance technique. Tellus, 59B, 449-457.

Riutta T, Laine J, Aurela M, Rinne J, Vesala T, Laurila T, Haapanala S, Pihlatie M, Tuittila E-S (2007) Spatial variation in plant community functions regulates carbon gas dynamics in a boreal fen ecosystem. Tellus, 59B, 838-852.

Roulet N, Lafleur PM, Richard PJ, Moore TR, Humphreys ER, Bubier J (2007) Contemporary carbon balance and late Holocene carbon accumulation in a northern peatland. Global Change Biology, 13, 397-411.

Sachs T, Wille C, Boike J, Kutzbach L (2008) Environmental controls on ecosystemscale $\mathrm{CH}_{4}$ emission from polygonal tundra in the Lena River Delta, Sibera. Journal of Geophysical Research-Biogeosciences, 113, G00A03.

Schindler DW, Curtis PJ (1997) The role of DOC in protecting freshwaters subjected to climatic warming and acidification from UV exposure. Biogeochemistry, 36, 1-8.

Schmid HP (1994) Source areas for scalars and scalar fluxes. Boundary-Layer Meteorology, 67 (3), 293-318.

Schrier-Uijl AP, Kroon PS, Hensen A, Leffelaar PA, Berendse F, Veenendaal EM (2010) Comparison of chamber and eddy covariance-based $\mathrm{CO}_{2}$ and $\mathrm{CH}_{4}$ emission estimates in a heterogeneous grass ecosystem on peat. Agricultural and Forest Meteorology, 150, 825-831.

Schuepp PH, Leclerc MY, Macpherson JI, Desjardins RL (1990) Footprint Prediction of Scalar Fluxes from Analytical Solutions of the Diffusion Equation. BoundaryLayer Meteorology, 50 (1-4), 355-373. 
Schuur EAG, Bockheim J, Canadell JG, Euskirchen E, Fie ld CB, Goryachkin SV, Hagemann S, Kuhry P, Lafleur PM, Lee H, Mazhitova G, Nelson FE, Rinke A, Romanovsky VE, Shiklomanov N, Tarnocai C, Venevsky S, Vogle JG, Zimov SA (2008) Vulnerability of Perma frost Carbon to Climate Change: Implications for the Global Carbon Cycle. BioScience, 58 (8), 701-714.

Segers S (1998) Methane production and methane consumption: a review of processes underlying wetland methane fluxes. Biogeochemistry, 41, 23-51.

Shumacher, BA (2002) Methods for the Determination of Total Organic Carbon (TOC) in Soils and Sediments. United States Environmental Protection Agency. Las Vegas, USA.

Soegaard H, Nordstroem C (1999) Carbon dioxide exchange in a high-arctic fen estimated by eddy covariance measurements and modeling. Global Change Biology, 5, 547-562.

Strack M, Waddington JM, Tuittila ES (2004) Effect of water table drawdown on northern peatland methane dynamics: Implications for climate change. Global Biogeochemical Cycles, 18, GB4003.

Strack M, Kellner E, Waddington JM (2005) Dynamics of biogenic gas bubbles in peat and their effects on peatland biogeochemistry. Global Biogeochemical Cycles, 19, GB1003.

Strack M, Waddington JM, Rochefort L, Tuittila ES (2006) Response of vegetation and net ecosystem carbon dioxide exchange at different peatland micro forms to water table drawdown. Journal of Geophysical Research-Biogeosciences, 111(G2), G02006.

Strack M, Waddington JM, Bourbonniere RA, Buckton EL, Shaw K, Whittington P, Price JS (2008) Effect of water table drawdown on peatland dissolved organic carbon export and dynamics. Hydrological Processes, 22, 3373-3385.

Strack M, Price JS (2009) Moisture controls on carbon dioxide dynamics of peatSphagnum monoliths. Ecohydrology, 2, 34-41.

Strom L, Ekberg A, Mastepanov M, Christensen TR (2003) The effect of vascular plants on carbon turnover and methane emissions from a tundra wetland. Global Change Biology, 9, 1185-1192.

Sullivan FS, Arens SJT, Chimner RA, Welker JM (2008) Temperature and Microtopography Interact to Control Carbon Cycling in a High Arctic Fen Ecosystems, 11, 61-76. 
Tarnocai C (2000) Carbon pools in soils of the Arctic, subarctic, and boreal regions of Canada. In: Global Climate Change and Cold region Ecosystems. Advances in Soil Science (edsLal R, Kimble JM, Stewart BA), pp. 91-103. CRC Press LLC, New York.

Tarnocai C, Canadell JG, Schuur EAG, Kuhry P, Mazhitova G, Zimov S (2009) Soil organic carbon pools in the northern circumpolar permafrost region. Global Biogeochemical Cycles, 23, GB2023.

Tokida T, Miyazaki T, Mizoguchi M, Nagata, Takakai F, Kagemota A, Hatano R (2007) Falling atmospheric pressure as a trigger for methane ebullition from peatland. Global Biogeochemical Cycles, 21, GB2003.

Torn MS, Chapin FS (1993) Environmental and biotic controls over methane flux from arctic tundra. Chemosphere, 26 (1-4), 357-368.

Treat CC, Bubier JL, Varner RK, Crill PM (2007) Timescale dependence of environmental and plant-mediate controls on $\mathrm{CH}_{4}$ flux in a temperate fen. Journal of Geophysical Research-Biogeosciences, 112(G1), G01014.

Twine TE, Kustas WP, Norman JM, Cook DR, Houser PR, Meyers TP, Prueger JH, Starks PJ, Wesely ML (2000) Correcting eddy-covariance flux underestimates over a grassland. Agricultural and Forest Meteorology, 103, 279-300.

Vourlitis GL, Oechel WC (1999) Eddy covariance measurements of CO2 and energy fluxes of an Alaskan tussock tundra ecosystem. Ecology, 80, 686-701.

Vourlitis GL, Harazono Y, Oechel WC, Yoshimoto M, Mano M (2000) Spatial and temporal variations in hectare-scale net $\mathrm{CO}_{2}$ flux, respiration and gross primary production of Arctic tundra ecosystems. Functional Ecology, 14, 203-214.

Waddington JM, Roulet NT (1996) Atmosphere-wetland carbon exchanges: scale dependency of $\mathrm{CO}_{2}$ and $\mathrm{CH}_{4}$ exchange on the developmental topography of a peatland. Global biogeochemical Cycles, 10, 233-245.

Waddington JM, Roulet NT (1997) Groundwater flow and dissolved carbon movement in a boreal peatland. Journal of Hydrology, 191, 122-138.

Waldron S, F lowers H, Arlaud C, McFarlane S (2008) The significance of organic carbon and nutrient export from peatland-dominated landscapes subject to disturbance. Biogeosciences Discussion, 5, 1139-1174.

Walker DA, Raynolds MK, Daniels FJA, Einarsson E, Elvebakk A, Gould WA, Katenin AE, Kholod SS, Markon CJ, Melnikov ES, Moskalenko NG, Talbot SS, Yurtsev BA (2005) The Circumpolar Arctic vegetation map. Journal of Vegetation Science, 16, 267-282. 
Wangersky PJ (1993) Dissolved organic carbon methods: a critical review. Marine Chemistry, 41, 61-74.

Warner BG, Rubec CDA (1997) The Canadian Wetland Classification System, Second Edition. Waterloo Canada: Wetland Research Centre, University of Waterloo.

Webb EK, Pearman GI, Leuning R (1980) Correction of flux measurements for density effects due to heat and water-vapour transfer. Quarterly Journal of the Royal Meteorological Society, 106(447), 85-100.

Welker JM, Fahnestock JT, Henry GHR, O'Dea KW, Chimner RA (2004) CO2 exchange in three Canadian High Arctic ecosystems: response to long-term experimental warming. Global Change Biology, 10, 1981-1995.

Whalen SC (2005) Biogeochemistry of Methane Exchange between Natural Wetlands and the Atmosphere. Environmental Engineering Science, 22 (1), 73-94.

Whalen SC, Reeburgh WS (1990) Consumption of atmospheric methane by tundra soils. Nature, 346, 160-163.

Whalen SC, Reeburgh WS, Barber VA (1992) Oxidation of methane in Boreal forest soils - A comparison of 7 measures. Biogeochemistry, 16, 181-211.

Wille C, Kutzbach L, Sachs T, Wagner D, Pfeiffer E-M (2008) Methane emission from Siberian arctic polygonal tundra: eddy covariance measurements and modeling. Global Change Biology, 14, 1395-1408.

Wilson KS, Humphreys ER (2010) Carbon Dioxide and methane fluxes from Arctic mudboils. Canadian Journal of Soil Science, 90 (3), 441-449.

Worrall F, Reed M, Warburton J, Burt T (2003) Carbon budget for a British upland peat catchment. The Science of the Total Environment, 312, 133-146.

Wuebbles DJ, Hayhoe K (2002) Atmospheric methane and global change. Earth-Science Reviews, 57, 177-210.

Zhang T, Barry RG, Knowles K, Heginbottom JA, Brown J. (1999) Statistics and characteristics of permafrost and ground-ice distribution in the Northern Hemisphere. Polar Geography, 23: 132-154.

Zhuang QL, Melillo JM, Sarofirn MC, Kicklighter DW, McGuire AD, Felzer BS, Sokolov A, Prinn RG, Steudler PA, Hu SM (2006) $\mathrm{CO}_{2}$ and $\mathrm{CH}_{4}$ exchanges between land ecosystems and the atmosphere in northern high latitudes over the $21^{\text {st }}$ century. Geophysical Research Letters. 33 (17), L17403. 
Zimov SA, Walter KM, Chanton JP (2006) Methane bubbling from Siberian thaw lakes as a positive feedback to climate warming. Nature, $443,71-75$.

Zimov SA, Schuur EAG, Chapin FS (2006b) Permafrost and the global carbon budget. Science, 312, $1612-1613$. 